UNIVERSIDADE DE SÃO PAULO

FACULDADE DE FILOSOFIA, LETRAS E CIÊNCIAS HUMANAS

DEPARTAMENTO DE HISTÓRIA

PROGRAMA DE PÓS-GRADUAÇÃO EM HISTÓRIA SOCIAL

MARCELO TEIXEIRA

A SUSTENTABILIDADE NA RMSP ATRAVÉS DO SANEAMENTO BÁSICO:

SABESP UM ESTUDO DE CASO

v. 1

São Paulo

2010 
UNIVERSIDADE DE SÃO PAULO

FACULDADE DE FILOSOFIA, LETRAS E CIÉNCIAS HUMANAS

DEPARTAMENTO DE HISTÓRIA

PROGRAMA DE PÓS-GRADUAÇÃO EM HISTÓRIA SOCIAL

\title{
A SUSTENTABILIDADE NA RMSP ATRAVÉS DO SANEAMENTO BÁSICO: SABESP UM ESTUDO DE CASO
}

\author{
Marcelo Teixeira
}

Dissertação apresentada ao Programa de

Pós-Graduação em História Social do

Departamento de

História da Faculdade de Filosofia,

Letras e Ciências Humanas da

Universidade de São Paulo, para a

obtenção do título de Mestre em História.

Orientador: Prof. Dr. Shozo Motoyama

v.1

São Paulo

2010 
A minha esposa, companheira, parceira, sócia e amiga Ana Fidalgo pelo apoio, paciência, força, colaboração, estimulo e tantos outros valores primordiais na vida de um ser humano. 


\section{Agradecimentos Especiais}

Agradeço aos meus pais, Gesner e Ana pela base, amor, educação e civilidade, que me deram, ensinamentos que me fortificam todo dia.

Também a meus "pseudo-pais" Oswaldo e Carmen pelo constante apoio e estimulo a percorrer o caminho da pesquisa acadêmica.

A Profa. Dra. Mônica Junqueira pelo "despertar" do amor a História ainda na graduação e na orientação de meu primeiro trabalho de pesquisa.

E especialmente ao meu orientador Prof. Dr. Shozo Motoyama, ao exemplo, ao suporte, a orientação e a paciência por ele gentilmente cedido a mim nesse projeto. 


\section{Agradecimentos}

Agradeço a todos que colaboraram diretamente ou indiretamente nesse trabalho com informações, apoio, paciência, material, enfim, tudo que nem sempre aparece, mas é fundamental para a realização de uma pesquisa.

A Companhia de Saneamento Básico de São Paulo (Sabesp).

A Secretaria de Habitação do Município de São Paulo (SEHAB-PMSP).

A Faculdade de Filosofia, Letras e Ciências Humanas - USP.

A Universidade de São Paulo.

Aos entrevistados Carlos Carrela (Sabesp), Ricardo Corrêa Sampaio (SEHABPMSP), Rui Agnaldo (Sabesp), Marco Antonio de Oliveira (Sabesp, Prof. Dr. Douglas Barreto (IPT) e Gilmar Massone ( Sabesp).

Aos amigos Hlldeberto Rodrigues (BBL Engenharia), Andre Rodrigues Oliveira e Silva (Vitalux) e Antonio Ramires (Restor) pelas informações técnicas.

Aos meus primos Marcos Milanesi, Carlos Sengeer e Euclydes Antonio Teixeira Neto pelo apoio técnico.

A minha irmã Ana e às minhas outras pseudo-irmãs pelo constante apoio.

Ao Prof. Dr. Sandro Caramaschi pelas infindáveis conversas.

Ao Sergio Miller pela paciência e pelas tantas transcrições.

Ao Centro de História da Ciência da USP nas pessoas de Adriana, Joana, Prof. Dr., Francisco Queiroz e Profa. Dra. Marilda Nagamini pelo apoio e estímulo.

Aos contemporâneos Marcelo Barros e Rafael Yamini.

E àqueles que se não citados, pela falta de espaço, não esquecidos, pela importância. 
Marco Polo descreve uma ponte, pedra por pedra.

- Mas qual é a pedra que sustenta a ponte? - pergunta Kublai Khan.

A ponte não é sustentada por esta ou aquela pedra - Responde Marco

- Mas pela curva do arco que estas formam.

Kublai Khan permanece em silêncio, refletindo. Depois acrescenta.

- Por que falar das pedras ? Só o arco me interessa.

- Polo responde - Sem pedras não há arco.

Cidades Invisíveis

de Ítalo Calvino 



\section{RESUMO}

\section{A SUSTENTABILIDADE NA RMSP ATRAVÉS DO SANEAMENTO BÁSICO: SABESP UM ESTUDO DE CASO}

O trabalho consiste em entender o papel de uma empresa de saneamento, a Sabesp, Companhia de Saneamento Básico de São Paulo, na sustentabilidade da Região Metropolitana de São Paulo, RMSP, através de seus projetos estruturantes: Projeto Tietê, Projeto Vida Nova, Córrego Limpo e o PURA. Para tanto, foram analisados os dados oficiais dos programas desenvolvidos pela companhia paulista juntamente com depoimentos dos profissionais envolvidos com os projetos, com especialista do Instituto de Pesquisas Tecnológicas - IPT e do responsável pelo Programa Vida Nova da PMSP. A partir de então, pôde-se concluir que, apesar do bom encaminhamento dos programas e de suas ações serem multidisciplinares, é necessário que, para que se tenha um resultado efetivo, todas as ações sejam pensadas e desenvolvidas de forma ampla e sistemática, com participação intensa e colaborativa de toda a sociedade bem como de agentes públicos e privados e em longo prazo.

Palavras Chaves: Saneamento Básico, Sabesp, Sustentabilidade Urbana, Urbanismo, RMSP. 


\section{ABSTRACT \\ The sustainability of RMSP through the sewerage system: Sabesp, object of study.}

The work consists in understanding the role of a sanitation company, Sabesp, the Basic Sanitation Company of São Paulo, at the sustainability of São Paulo's Metropolitan Region (RMSP), by means of its structuring projects: Projeto Tietê, Projeto Vida Nova, Córrego Limpo and PURA. In order to do that, the official data of the developed programs by the São Paulo's company have been analyzed, together with the statements of the professionals involved with the projects, with the expert of the Instituto de Pesquisa Tecnológica - IPT and the responsible for the Programa Vida Nova of São Paulo's City Hall. From then on, it was possible to conclude that, despite the good management of the programs and that their actions are multitasks, it is necessary that, in order to achieve an effective result, all actions are reasoned and developed in a broad and systematic way, with an intense and collaborative participation of all society as well as the public and private players and in the long term.

Keywords: Sabesp, urban sustainability, São Paulo, sewerage system, RMSP. 


\section{Lista de ilustrações}

Figura 1 - Região Metropolitana de São Paulo 24

Figura $2 \quad$ - Mancha de poluição em 1990, antes da primeira etapa do 31 Projeto Tietê

Figura $3 \quad$ - Mancha de poluição em 2001

Figura $4 \quad$ - Mancha de poluição, estimativa a partir de 2008

Figura 5 - Projeto Tietê - Evolução dos índices de tratamento de 158 esgotos

Figura 6 - Projeto Tietê - Evolução dos índices de coleta de esgotos 159

Figura $7 \quad$ - Expansão do sistema integrado 160

Figura $8 \quad$ - Áreas de Intervenção do Programa Vida Nova 161

Figura 9 - Intervenção Bacia Guavirutuba 162

Figura $10 \quad$ - Intervenção Bacia Itupu 163

Figura $11 \quad$ - Intervenção Bacia Rio Bonito 164

Figura $12 \quad$ - Intervenção Bacia Rio das Pedras 165

Figura $13 \quad$ - Intervenção Bacia Tanquinho 166

Figura $14 \quad$ - Intervenção Bacia Culin Montante $\quad 167$

Figura $15 \quad$ - Intervenção Bacia Sete Campos 168

Figura 16 - Áreas de intervenção do Córrego Limpo 169

Fotografia 1 - Poluição do Rio Tietê 22

Fotografia 2 - Manifestação de apoio 23

Fotografia 3 - ETE São Miguel 25

Fotografia 4 - ETE Parque Novo Mundo 25

$\begin{array}{lll}\text { Fotografia } 5 & - \text { ETE ABC } & 26\end{array}$

Fotografia 6 - ETE Barueri 26

$\begin{array}{lll}\text { Fotografia } 7 & \text { - ETE Suzano } & 27\end{array}$ 
$\begin{array}{lll}\text { Fotografia } 8 & \text { - Interceptor } & 27\end{array}$

$\begin{array}{lll}\text { Fotografia } 9 & \text { - Interceptor } & 27\end{array}$

Fotografia 10 - Coletor tronco 28

Fotografia 11 - Coletor tronco 28

Fotografia 12 - Represa Billings 37

Fotografia 13 - Represa Guarapiranga 40

Fotografia 14 - Cantinho do Céu $\quad 41$

Fotografia 15 - Córrego Charles de Gaulle $\quad 45$

Fotografia 16 - Córrego Carajás/ Carandiru 47

Fotografia 17 - Torneira para lavatório de mesa 50

Fotografia 18 - Torneira para lavatório de parede 50

Fotografia 19 - Registro regulador de vazão 51

Fotografia 20 - Torneira para lavatório de mesa $\quad 51$

Fotografia 21 - Válvula para água fria ou pré-misturada - chuveiro 51

Fotografia 22 - Acabamento para válvula de descarga antivandalismo 51

Gráfico $1 \quad$ - Evolução dos índices de coleta e tratamento 21

Quadro $1 \quad$ - Quadro comparativo de equipamentos economizadores 52

Quadro 2 - Locais de intervenção do PURA 57

Quadro 3 - Previsão do término de obras 162

Quadro $4 \quad$ - Previsão do término de obras 163

Quadro 5 - Previsão do término de obras 164

Quadro $6 \quad$ - Previsão do término de obras 165

Quadro 7 - Previsão do término de obras 166

$\begin{array}{lll}\text { Quadro } 8 & \text { - Previsão do término de obras } & 167\end{array}$

Quadro $9 \quad$ - Previsão do término de obras 168 


\section{Lista de tabelas}

Tabela 1 - Crescimento da população favelada no município de São

Paulo

Tabela 2 - Relação de coleta e tratamento de esgoto no Projeto Tietê 


\section{Lista de abreviaturas e siglas}

$\begin{array}{ll}\text { ABC } & \text { Santo André, São Bernardo, São Caetano } \\ \text { ABNT } & \text { Associação Brasileira de Normas Técnicas } \\ \text { ACIESP } & \text { Academia de Ciências do Estado de São Paulo } \\ \text { BID } & \text { Banco Interamericano de Desenvolvimento } \\ \text { BNH } & \text { Banco Nacional de Habitação } \\ \text { CDHU } & \text { Companhia de Desenvolvimento Habitacional e Urbano } \\ \text { CESBS } & \text { Companhia Estadual de Saneamento Básico } \\ \text { CETESB } & \text { Companhia Ambiental do Estado de São Paulo } \\ \text { COMASP } & \text { Companhia Metropolitana de Águas de São Paulo } \\ \text { DAE } & \text { Departamento de Água e Energia } \\ \text { DAEE } & \text { Departamento de Águas e Energia Elétrica } \\ \text { ETE } & \text { Estação de Tratamento de Esgotos } \\ \text { FESB } & \text { Fomento Estadual de Saneamento Básico } \\ \text { IPT } & \text { Instituto de Pesquisas Tecnológicas do Estado de São Paulo } \\ \text { NBR } & \text { Norma Brasileira } \\ \text { PAC } & \text { Programa da Aceleração do Crescimento } \\ \text { PLANASA } & \text { Plano Nacional de Saneamento } \\ \text { PMSP } & \text { Prefeitura Municipal de São Paulo } \\ \text { PURA } & \text { Programa de Uso Racional da Água } \\ \text { RMSP } & \text { Região Metropolitana de São Paulo } \\ \text { SABESP } & \text { Companhia de Saneamento Básico do Estado de São Paulo } \\ \text { SAEC } & \text { Superintendência de Água e Esgotos da Capital } \\ \text { SANEGRAN } & \text { Projeto de Saneamento para a Grande São Paulo } \\ \text { SANESP } & \text { Companhia Metropolitana de Saneamento Básico } \\ \text { SANEVALE } & \text { Companhia Regional de Águas e Esgotos do Vale do Ribeira } \\ \text { SBS } & \text { Companhia de Saneamento Básico da Baixada Santista } \\ \text { SRHSO } & \text { Secretaria de Recursos Hídricos, Saneamento e Obras } \\ \text { VDR } & \text { Válvula de Restrição de Vazão } \\ \text { USP } & \text { Universidade de São Paulo }\end{array}$


$L p F$ :

$D B O / d i a$ :

$\mathrm{m}^{3} / \mathrm{s}$ :
Litros por Fluxo

[lpf]

Carga Orgânica do Esgoto [kg]

Metros cúbicos por segundo $\left[\mathrm{m}^{3} / \mathrm{s}\right]$ 


\section{Sumário}

1 INTRODUÇÃO

2 SABESP - SEUS PRIMÓRDIOS $\quad 16$

3 PROJETO TIETÊ

4 PROGRAMA VIDA NOVA (MANANCIAIS) 36

5 CÓRREGO LIMPO 42

7 PURA - PROGRAMA DE USO RACIONAL DA ÁGUA 48

8 CONCLUSÃO $\quad 59$

$\begin{array}{ll}\text { Referências } & 61\end{array}$

Apêndice A - Entrevista com Agnaldo Ruivo (Sabesp) 63

Apêndice B - Entrevista com Carlos Carrela (Sabesp) 91

Apêndice C - Entrevista com Ricardo Corrêa Sampaio (PMSP) 104

Apêndice D - Entrevista com Douglas Barreto (IPT) 110

Apêndice E - Entrevista com Marco Antônio de Oliveira (Sabesp) 134

Apêndice F - Entrevista com Gilmar Massone (Sabesp) 137

Anexo A - Resumo dos resultados do Projeto Tietê 158

Anexo B - Áreas de intervenção do Programa Vida Nova 161

Anexo C - Áreas de intervenção do Córrego Limpo 169 


\section{INTRODUÇÃO}

São Paulo vem crescendo vertiginosamente e desordenadamente desde o século XIX.

A cidade deixou de ser uma província para se tornar uma das maiores cidades do mundo com cerca de 25 milhões de habitantes como Benévolo nos diz:

As cidades brasileiras crescem muito rapidamente, e, entre elas, São Paulo mais que qualquer outra. A velocidade é tão grande, a ponto de apagar, no espaço de uma vida humana, o ambiente de uma geração anterior: os jovens não conhecem a cidade onde, jovens como eles, viveram os adultos. Assim as lembranças são mais duradouras que o cenário construído, e não encontram nele um apoio e um reforço. Os estudos históricos tornam-se, então, duplamente necessários, para que não se deixem cair no esquecimento os cenários da vida passada, e para restituir profundidade à experiência do ambiente urbano. (TOLEDO, 1983, p.7)

Tal crescimento urbano levou à cidade números vertiginosos, no trânsito, nas edificações, na infra-estrutura, no transporte coletivo, enfim, em todas as questões urbanas necessárias para manter uma megalópole funcionando.

Por outro lado tais necessidades urbanas não acompanharam esse crescimento de maneira satisfatória. O saneamento básico, por exemplo, foi um desses casos. Passou todo o século correndo atrás desse crescimento, tentando supri-lo da melhor maneira possível, o que só ocorrerá, em parte, no fim do século XX após algumas mudanças estruturais políticas e administrativas.

Pode-se dividir a trajetória do Saneamento Básico em São Paulo em três grandes fases, até 1970 a Higienista quando se preocupava com o abastecimento de água sem tratamento de esgoto e a transferência para jusante do escoamento pluvial por canalização, entre 1970 e 1990, a corretiva, Tratamento de esgoto, amortecimento quantitativo da drenagem e controle do impacto existente da qualidade da água pluvial. E, por fim, a partir da década de 90 , a sustentável quando envolve 
principalmente a atuação sobre os impactos, e, o planejamento da ocupação do espaço urbano obedecendo aos mecanismos naturais de escoamento; Controle dos micro-poluentes, da poluição difusa e o desenvolvimento sustentável do escoamento pluvial através da recuperação da infiltração.

Assim sendo, além de tentar suprir as necessidades paulistas em questões ao saneamento, novas demandas se mostraram prioritárias. A necessidade de se rever o passado e repensar as atitudes até então tomadas se mostra fundamental para se construir uma metrópole sustentável. Sustentável não só do ponto de vista ambiental, mas urbano e econômico a fim de torná-la uma metrópole viável com cerca de vinte milhões de habitantes.

Nesse ponto, a Sabesp se coloca como um importante agente uma vez que grande parte das questões relativas ao desenvolvimento urbano sustentável passa pela questão da Água, desde sua captação e distribuição, percorrendo as formas de tratamento do esgoto até o uso e reuso da água bem como a proteção dos recursos hídricos existentes.

Para tanto, será adotado como definição de Desenvolvimento Sustentável, o termo de acordo com as seguintes referências:

Conceito originado em 1968 na Biosphere Conference de Paris. Modelo de desenvolvimento que levam em consideração, além dos fatores econômicos, aqueles de caráter social e ecológico, assim como as disponibilidades dos recursos vivos e inanimados, e as vantagens e os inconvenientes, a curto e, em longo prazo, de outros tipos de ação (ACIESP, 1997, p.73).

Processo de desenvolvimento econômico em que se procura preservar o meio ambiente, levando-se em conta os interesses das gerações futuras (FERREIRA, 1999, p.650). 
Esse trabalho tem como objetivo compreender, através de dados técnicos, depoimentos dos coordenadores dos projetos estudados, e de profissionais especialistas, como o saneamento básico na Região Metropolitana de São Paulo (RMSP), vem colaborando para a sustentabilidade urbana de uma cidade com cerca de 25 milhões através da Sabesp e de seus principais projetos estruturantes atuantes na região, o Projeto Tietê, o Programa de Uso Racional da Água (PURA), o Programa Vida Nova e o Projeto Córrego Limpo.

Esses quatro projetos atuam diretamente ou indiretamente na questão da água e do Meio Ambiente, procurando despoluir, recuperar e preservar as fontes hídricas da capital paulista ou, no caso do PURA, gerenciar o consumo desse bem.

\section{Sabesp - Seus primórdios}

No final da década de 1960, os sistemas de saneamento básico se encontravam, na maioria dos casos, sob a gestão das prefeituras através da criação de Companhias estaduais de saneamento básico (CESBS).

Com a ascensão dos militares ao poder, houve uma centralização nas decisões estratégicas do país, ocorrendo o mesmo no saneamento básico, culminando na criação do Plano Nacional de Saneamento (PLANASA), em 1968 com a finalidade de viabilizar um alto volume de investimentos no setor. A forma utilizada para tal foi a realização de um esforço para que as companhias estaduais de saneamento (CESBS) recebessem dos municípios as concessões dos serviços de saneamento. Estas se tornariam, assim, as responsáveis por todas as ações de saneamento nos estados brasileiros.

O PLANASA seria importante, pois trouxe uma nova visão do saneamento como elemento de infra-estrutura urbana estratégica para o desenvolvimento econômico nas grandes cidades brasileiras fortalecendo o setor como gerador de um processo 
de reaquecimento econômico para os diversos capitais envolvidos e para a rápida geração de empregos.

O modelo institucional implantado com o PLANASA levou os Estados a constituírem empresas públicas ou sociedades de economia mista, os CESBS, que passaram a prestar o serviço nos Municípios, mediante a celebração de contratos de concessão. Este modelo foi induzido pela União por meio dos critérios para destinação dos financiamentos do FGTS, que foram alocados exclusivamente às empresas estaduais. A prestação por empresas estaduais abrangeu aproximadamente $75 \%$ dos Municípios.

O instrumento principal para a implantação do PLANASA são as empresas estaduais estatais, que incorporaram em sua administração os conceitos da empresa capitalista de eficiência, produtividade e, principalmente, o retorno do capital investido.

Em 1968, foram criadas em São Paulo a Companhia Metropolitana de Águas de São Paulo (COMASP), de economia mista, responsável pela captação, tratamento, venda e distribuição para 37 municípios da RMSP, a Companhia Regional de Águas e Esgotos do Vale do Ribeira (SANEVALE) e também a Companhia de Saneamento Básico da Baixada Santista (SBS).

Em 1969, foi criado o Fomento Estadual de Saneamento Básico (FESB), com o objetivo de desenvolver o saneamento básico do Estado de São Paulo e, em 1970, a Companhia Metropolitana de Saneamento Básico (SANESP), com a finalidade de interceptar, tratar e proceder a disposição final dos esgotos da Grande São Paulo, e a Superintendência de Água e Esgotos da Capital (SAEC), substituindo o antigo Departamento de Água e Esgoto (DAE) na tarefa de operar os sistemas de água e coleta de esgotos. 
Será nesse cenário em que se dará a criação da Companhia de Saneamento Básico do Estado de São Paulo - Sabesp, em 1973, pelo então governador Laudo Natel, promulgada através da Lei 119, unificando a COMASP, SANESP, SAEC, SBS, SANEVALE e FESB, com seu primeiro presidente o General Phelippe Galvão Carneiro da Cunha, como hábito da época.

A criação da Sabesp é o coroamento no Estado de São Paulo da estruturação de uma política setorial no Brasil, baseada na centralização do controle da execução de obras, operação técnica e gerenciamento financeiro dos sistemas de saneamento (BUENO, 1994, p.132).

A Sabesp terá, então, visto a população da capital paulista saltar na década de 70 para 6 milhões de habitantes dos 3,7 milhões da década de 60. Nesse cenário, a Sabesp trabalhará no intuito de ampliar consideravelmente o abastecimento de água, uma vez que além do crescimento da população encontrará pela frente o intenso surgimento de favelas, e, ainda, trabalhar a coleta e o tratamento de esgoto, até então em plano secundário e agravado pelo crescimento desordenado da cidade.

Tabela 1 - Crescimento da população favelada do Município de São Paulo

\begin{tabular}{c|c|c|c}
\hline Ano & $\begin{array}{c}\text { População } \\
\text { Favelada }\end{array}$ & $\begin{array}{c}\text { População } \\
\text { Total }\end{array}$ & $\begin{array}{c}\text { \% População } \\
\text { Favela/Total }\end{array}$ \\
\hline 1973 & 71.840 & 6.560 .547 & 1,09 \\
\hline 1980 & 375.023 & 8.587 .665 & 4,40 \\
\hline 1987 & 812.764 & 9.247 .560 & 8,78 \\
\hline 1991 & 1.071 .288 & 9.626 .898 & 11,12 \\
\hline
\end{tabular}

Fonte: IBGE, PMSP e SEADE, [199?] apud BUENO, 1994.

Em 1975, para se entender o volume dos esforços empregados nesse sentido, foram colocados em operação cerca de 1000 quilômetros de redes secas. Foi executado, através de um plano ousado do então presidente da companhia, Klaus Reinach, um 
programa de ligação gratuito de residências às redes, elevando o número de 3000 para 25000. Contrário a prática anterior do DAE e SAEC de esperar o pedido por parte do munícipe, e executar paulatinamente a ligação e cobrar seu custo na primeira conta, a nova ação transformou a imagem da companhia perante a sociedade, bem como teve um impacto significativo na melhora da qualidade de vida dos paulistas. Houve também a valorização da Sabesp como empresa tecnicamente eficiente e preocupada com o papel do saneamento público, legitimando o PLANASA e elevando o nível da opinião pública a seu respeito.

Nesse período, a Sabesp também concentrou esforços em aumentar significativamente a captação de água.

Logo após a sua criação, a companhia assumiria as obras do Sistema Cantareira entregando-a em 1981, contribuindo com $11 \mathrm{~m}^{3} / \mathrm{s}$ no abastecimento de São Paulo e iniciará, em 1979, a adutora Cantareira - Zona Leste, entregando-a em 1982 com 2,5 Km de diâmetro e 25 km de extensão.

Após uma fase de carência escandalosa de água é possível abastecer a capital e também os municípios próximos. Pode-se verificar uma cobertura quase total da mancha urbana, principalmente quando comparada à de 1969.

A década de 70 e 80 foi marcada pela regularização o abastecimento de água e pelo acalorado debate em torno do novo plano da Sabesp, o SANEGRAN. As criticas ao plano mobilizaram um grande número de técnicos importantes como Figueiredo Ferraz, Samuel Murgel Branco, entre outros. Elas atacavam desde seu "gigantismo", Ferraz em jornal O Estado de São Paulo - 22/06/1977, questões técnicas, o volume financeiro envolvido, o cronograma das obras, etc.

Em 1982, diversas partes do plano se encontravam atrasadas, tendo já consumido grande parte dos recursos previstos. E em 1983, com a redemocratização do país, o governo estadual pela primeira vez ocupado por um partido de oposição, o 
Governador Franco Montoro, haverá uma intensa revisão do plano e tenta-se um redirecionamento da Sabesp encabeçada pelo então presidente Gastão Bierrenbach, que de Janeiro de 1985 até Janeiro de 1987, realizaram diversos estudos reconsiderando a população estimada da capital, o tratamento de esgotos, que segundo Milton Vargas (1994), em 1985 representava apenas $40 \%$ da população existente, prevendo uma nova postura perante essa questão colocando-a como o novo paradigma da década de 90 , principalmente para o próximo século.

Na década de 90, o PLANASA entra em crise por diversos fatores, entre os quais, a utilização das CESBS como instrumento de clientelismo e fisiologismo, o fim do período de carência dos financiamentos anteriormente acordados e da crise fiscal generalizada em vários níveis do governo federal. As companhias estaduais se mostraram deficitárias, ineficazes, com alto índice de perdas, grande desperdício por parte dos usuários, bem como incapaz de manter e ou ampliar a infra-estrutura através da receita obtida pelas tarifas.

Em 1995, sob novo governo, o então Governador Mario Covas inicia uma ampla reestruturação da Sabesp através de choque administrativo e de um novo modelo empresarial cujos esforços se concentravam em saneamento financeiro e novos empreendimentos culminando em outro marco importante na história da Sabesp, sua entrada no mercado de capitais, em 2000. Tal ação acabou por exigir da companhia maior transparência, eficiência e rapidez a fim de captar recursos e confiança do mercado e responder à altura as demandas da sociedade e do investidor.

A partir da década de 90, as questões ambientais assumem importante papel quando se trata de saneamento básico. A ECO92, juntamente com uma demanda nacional e mundial, leva a Sabesp a assumir a sustentabilidade como foco nos trabalhos ao lado do seu grande desafio da Sabesp, a questão do tratamento de esgoto, o qual pouco avançou nas últimas décadas. Exemplo dessa postura foi o projeto Tietê, lançado em 1992, que desde então atacou, com recursos japoneses, a 
questão sanitária e, juntamente com outros projetos do governo estadual, as enchentes das marginais.
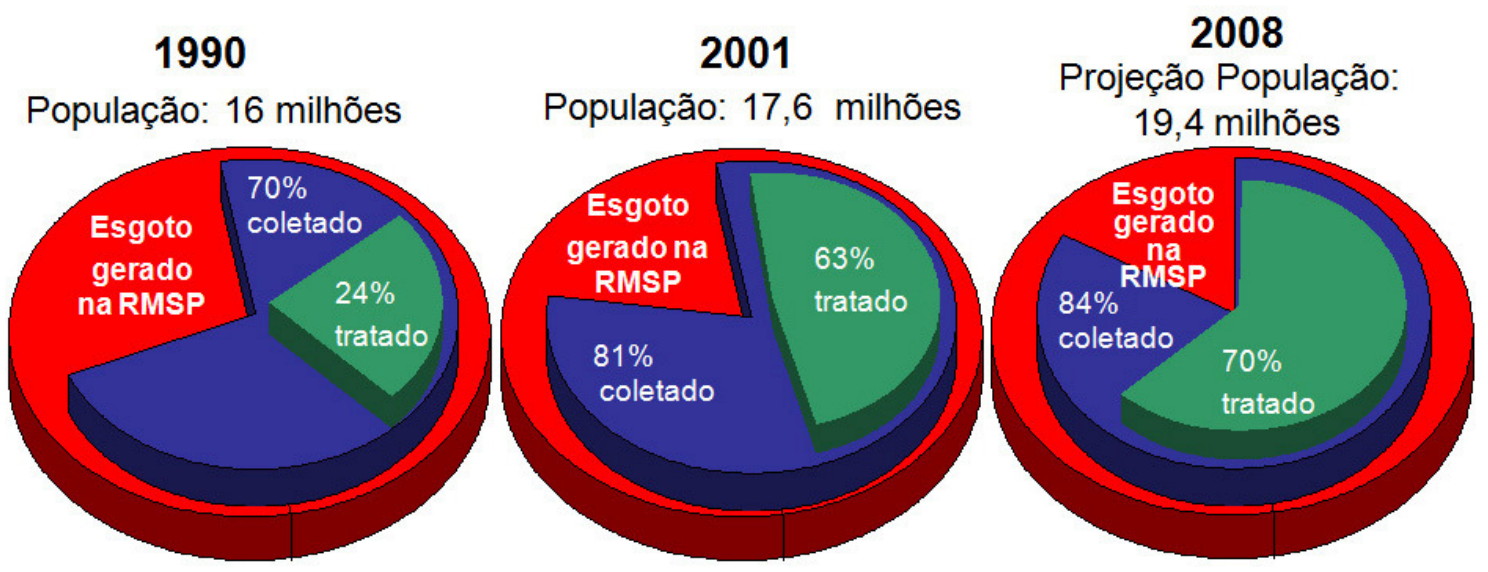

Gráfico 1 - Evolução dos índices de coleta e tratamento Fonte: Sabesp

O projeto Tietê, junto com o projeto Córrego Limpo e o Programa Vida Nova, vêm caminhando no sentido de minimizar as questões relativas ao esgoto. A grande barreira ainda se encontra na grande ocupação irregular, as favelas, nos fundos de vale, o que leva a inúmeras críticas ao projeto até então desenvolvido, por ser ineficiente e de caráter propagandístico, por desconsiderar realocação da população residente em favelas e mananciais.

Outra frente atacada pela Sabesp nos últimos anos caminha na direção da gestão da demanda de água, isto é, no uso racional dos recursos hídricos. Um dos principais projetos estruturantes nesse sentido é o PURA, Programa de Uso Racional da Água, que se caracteriza pela diminuição do consumo bem como o controle das perdas em edifícios públicos e privados. Através dessas ações locais, normatizando, renovando tecnologicamente os equipamentos sanitários e educando os usuários, esse programa da Sabesp procura minimizar o consumo e monitorar o mesmo de forma permanente em edifícios públicos e corporativos.

Assim sendo, com os programas estruturantes, a companhia paulista entra no século $\mathrm{XXI}$, procurando se transformar não mais numa empresa de saneamento para, como 
ela mesmo define, mas numa empresa de soluções ambientais, a nova demanda do século.

\section{PROJETO TIETÊ}

O projeto Tietê tem como objetivo resgatar a salubridade do rio paulista e vem sendo desenvolvido desde 1992, implementado pelo Governo Estadual de São Paulo, com a participação de diversas autarquias como Sabesp, CETESB e DAEE.

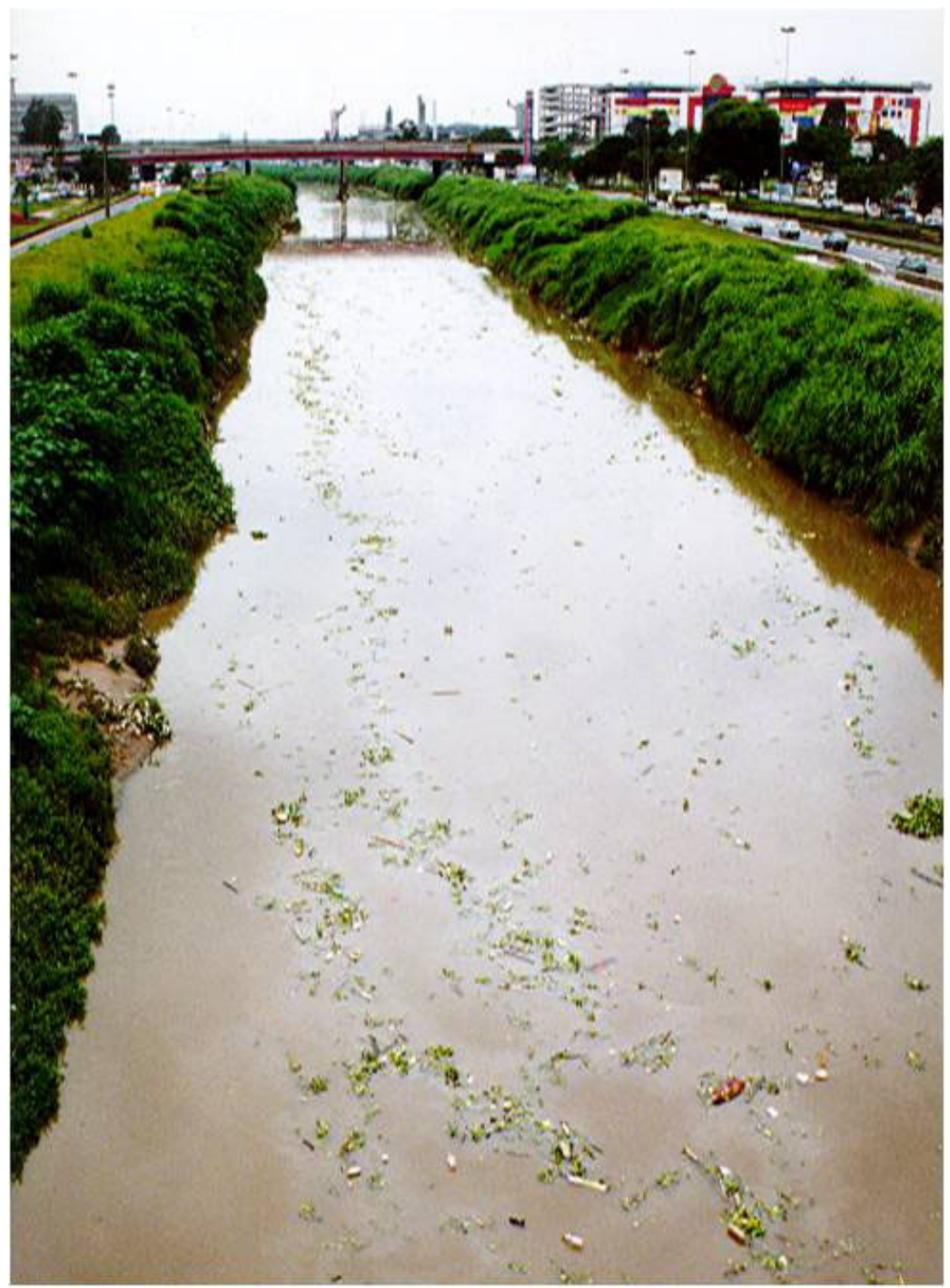

Fotografia 1 - Poluição do Rio Tietê

Fonte: Sabesp 
É importante ressaltar que no inicio da década de 90 a sustentabilidade começa a fazer parte das grandes discussões internacionais. Também em 1992, o Rio de Janeiro sedia a ECO 92 e o saneamento básico deixa de se preocupar apenas com questões higienistas ou corretivas para focalizar no problema ambiental.

Iniciou-se, segundo a Sabesp, após uma manifestação encabeçada pela Radio Eldorado e pelo Jornal da Tarde em Agosto de 1990, resultando em um ano, 1,2 milhão de assinaturas, maior abaixo-assinado da America Latina em prol de uma causa ambiental segundo a rádio Eldorado. Nesta época, a CETESB efetuou o diagnóstico das fontes de poluição das águas na Bacia do Alto Tietê, tendo sido estimado que os rios da bacia recebessem aproximadamente a carga orgânica de 1.200 toneladas de DBO/dia e 5 toneladas de carga inorgânica por dia, principalmente por metais, cianeto e fluoreto. As indústrias eram as responsáveis pela emissão da carga inorgânica, além de um terço da carga orgânica lançada na bacia, sendo o restante da carga orgânica originada pelos esgotos domésticos gerados pelos 17,7 milhões de habitantes dos 34 Municípios da Região Metropolitana de São Paulo.

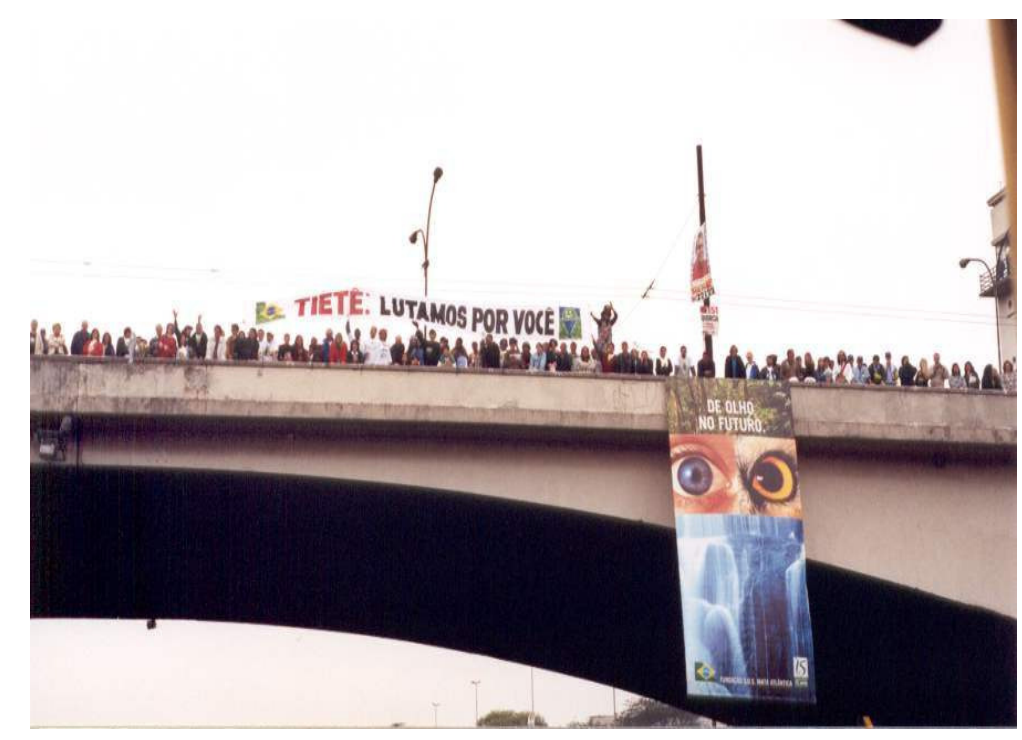

Fotografia 2 - Manifestação de Apoio a Despoluição do Rio Tietê Fonte: Sabesp 
Por se tratar de um Rio cujas características são bastante peculiares, sua despoluição apresenta um grande desafio para São Paulo, bem como para os agentes envolvidos como a Sabesp, pois, logo depois de sua nascente, já recebe uma grande carga poluente ao passar pela RMSP.

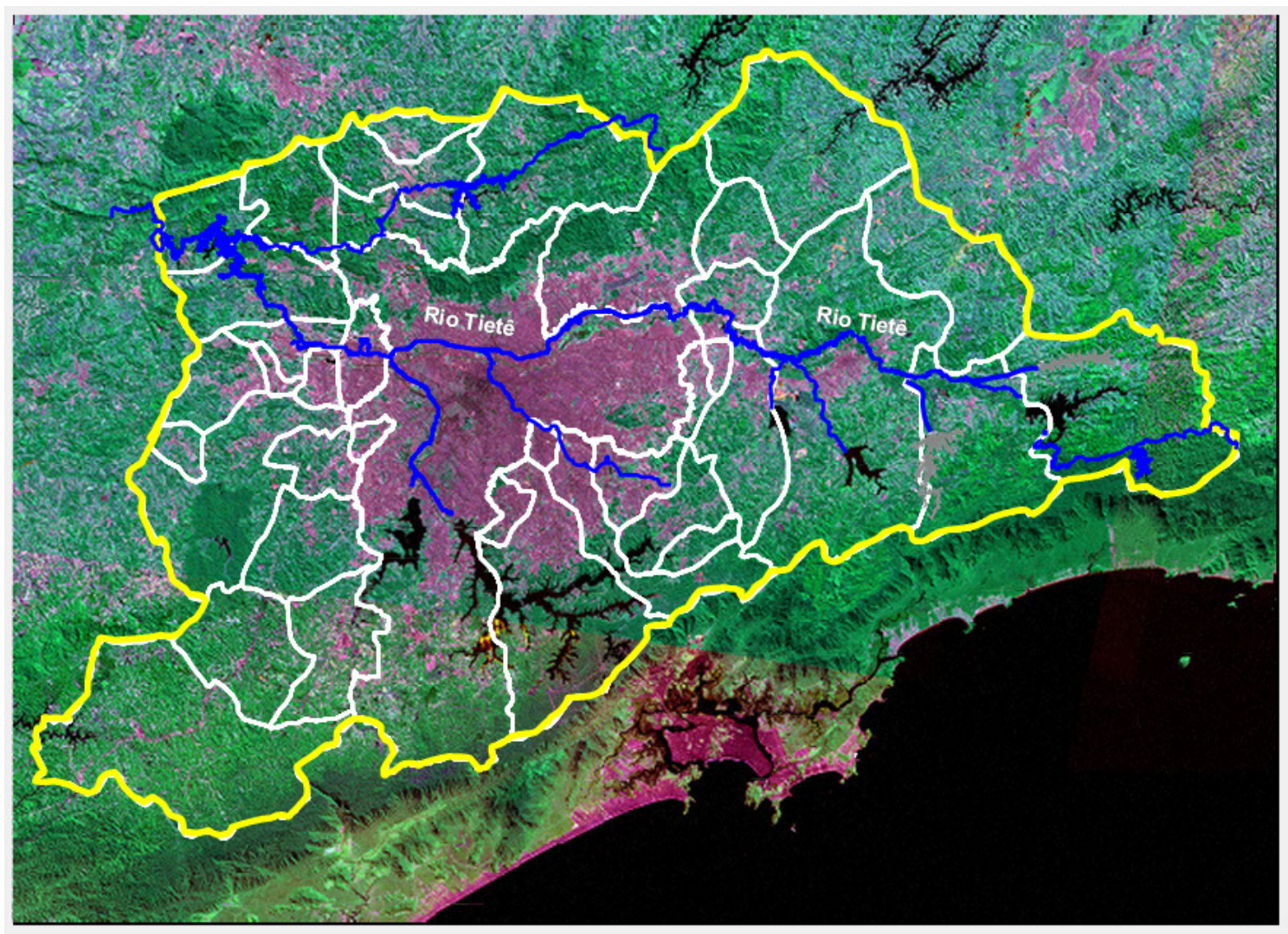

Figura 1 - Região Metropolitana de São Paulo Fonte: Sabesp

Assim sendo, o Projeto Tietê, iniciado em 1992, se concentrou, portanto, na ampliação da infra-estrutura da coleta e do tratamento de esgotos, como diz Carlos Carrela, Superintendente da TG, responsável pelas grandes obras do projeto.

O Projeto Tietê é impedir que o esgoto chegue ao rio, que seja lançado ao rio sem ser tratado, ou seja, o projeto prevê redes coletoras de esgoto para captar todo esgoto que é produzido na região metropolitana de São Paulo, levado a uma estação de tratamento e, sim, depois de tratado lançado ao rio (informação verbal) ${ }^{1}$.

\footnotetext{
${ }^{1}$ Informação obtida por entrevista, Apêndice B, com Carlos Carrela em 2010
} 
Tal interceptação do esgoto acontece, segundo o Projeto Tietê (92) através da construção de três Estações de Tratamento de Esgoto (ETE), São Miguel, Parque Novo Mundo e ABC, e obras de ampliação da ETE Barueri, que, juntamente com e ETE Suzano, tiveram aumentadas suas capacidades de tratamento de esgotos da RMSP em 9500 litros por segundo. Foram investidos US\$1,1 Bilhão somente nessa primeira fase, sendo o maior projeto de despoluição financiado pelo Banco Interamericano de Desenvolvimento.

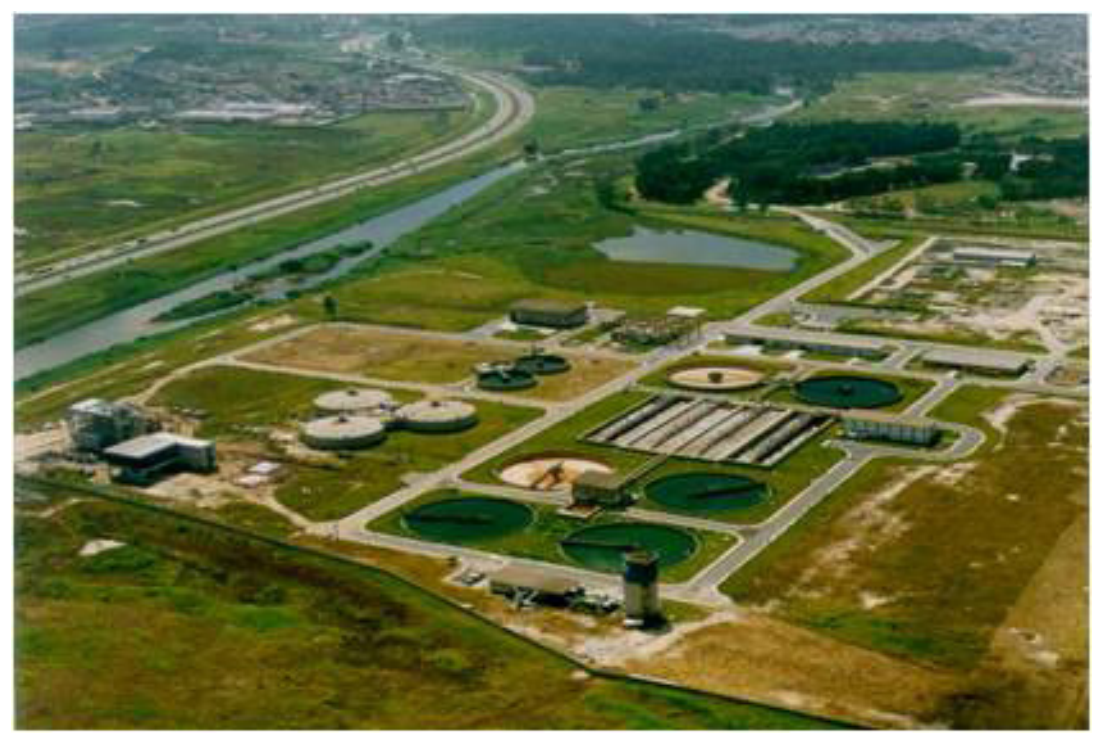

Fotografia 3 - ETE São Miguel Fonte: Sabesp

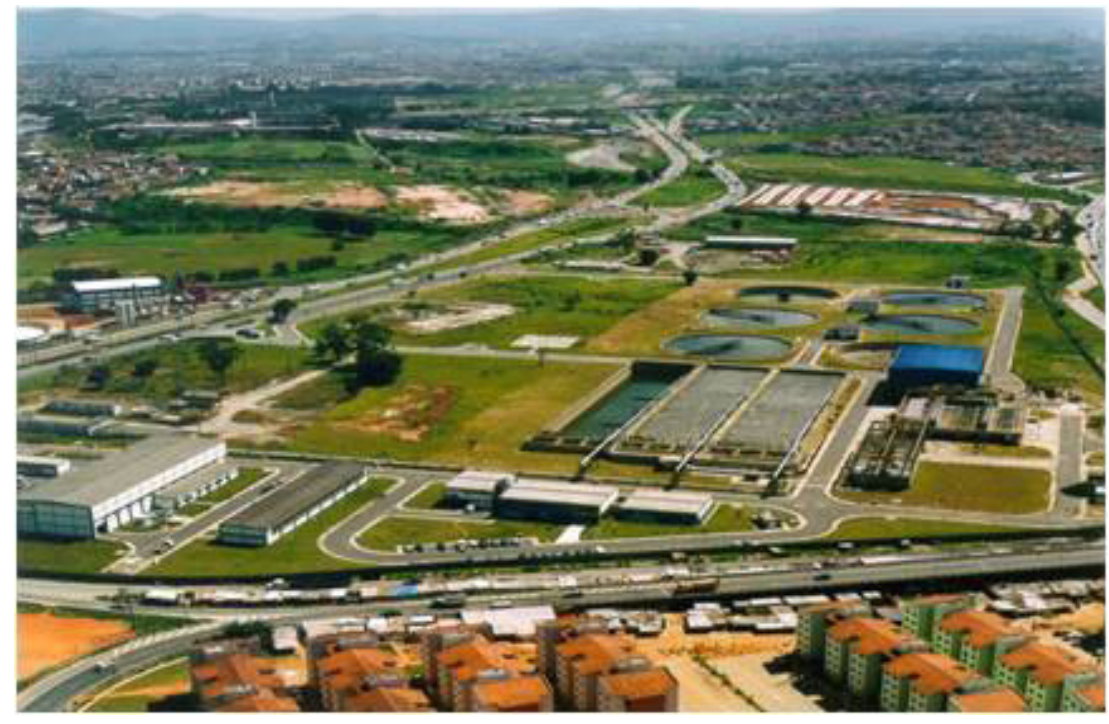

Fotografia 4 - ETE Parque Novo Mundo Fonte: Sabesp 


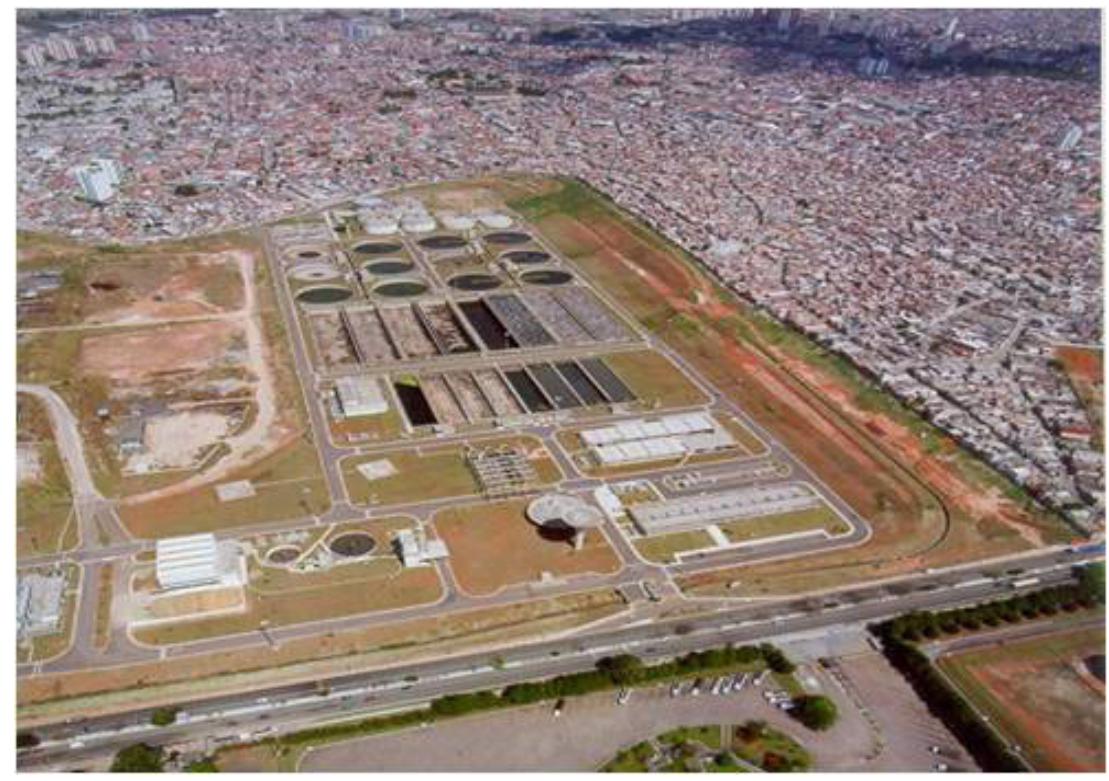

Fotografia 5 - ETE ABC

Fonte: Sabesp

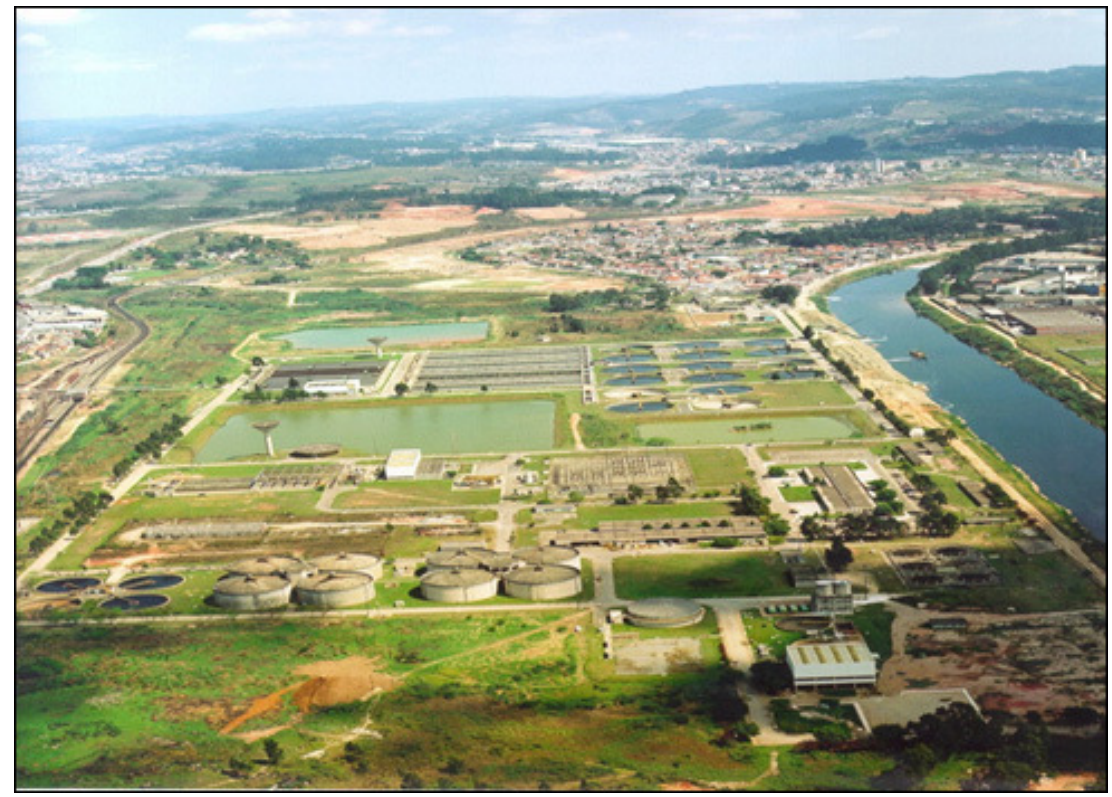

Fotografia 6 - ETE Barueri

Fonte: Sabesp 


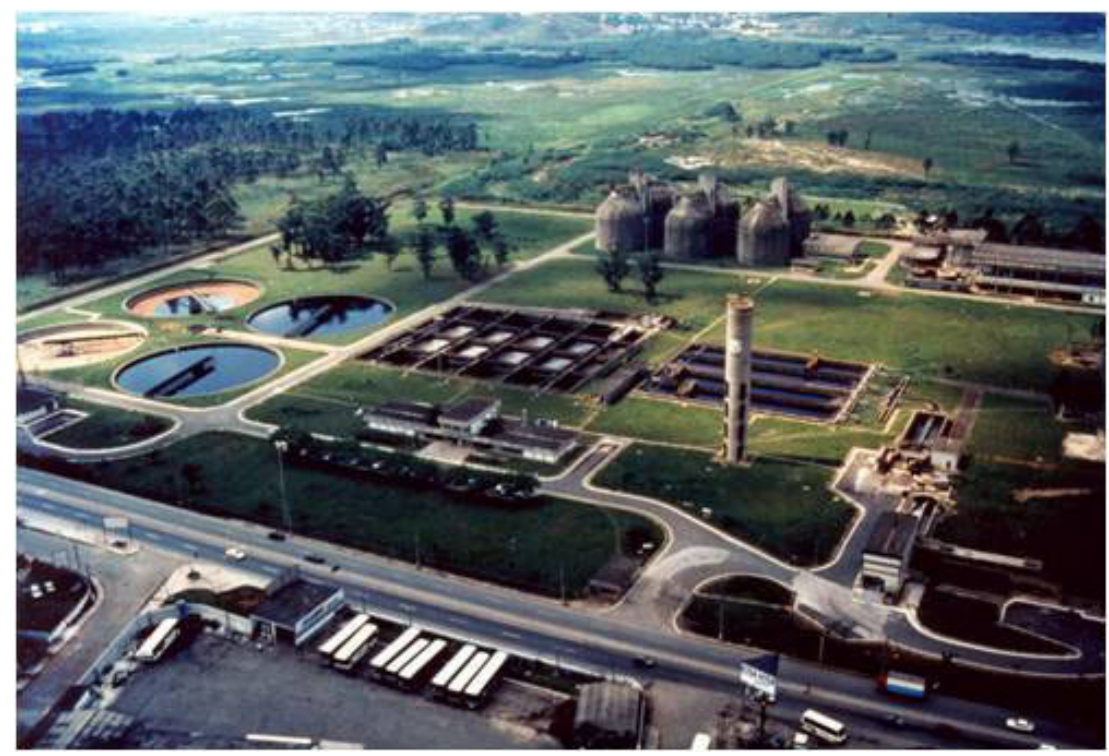

Fotografia 7 - ETE Suzano

Fonte: Sabesp

Nessa fase, foram implantados $1500 \mathrm{~km}$ de redes coletoras, 250 mil ligações domiciliares de esgoto e $352 \mathrm{~km}$ de coletor-troncos e interceptores elevando os índices de coleta de $66 \%$ em 1992, para $78 \%$ em 1998, e o tratamento, no mesmo período saltou de $24 \%$ para $63 \%$.

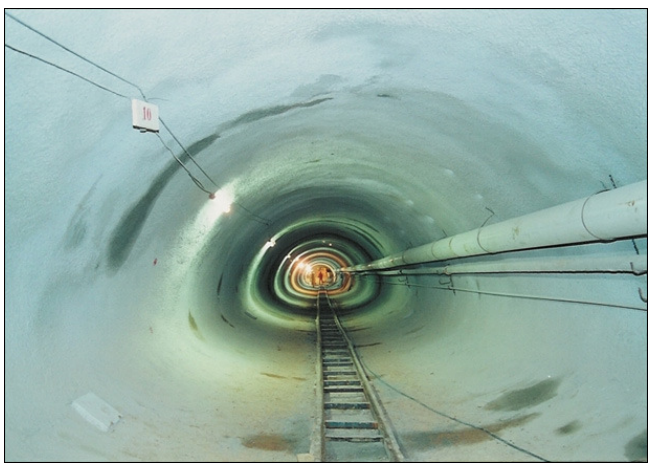

Fotografia 8 - Interceptor Fonte: Sabesp

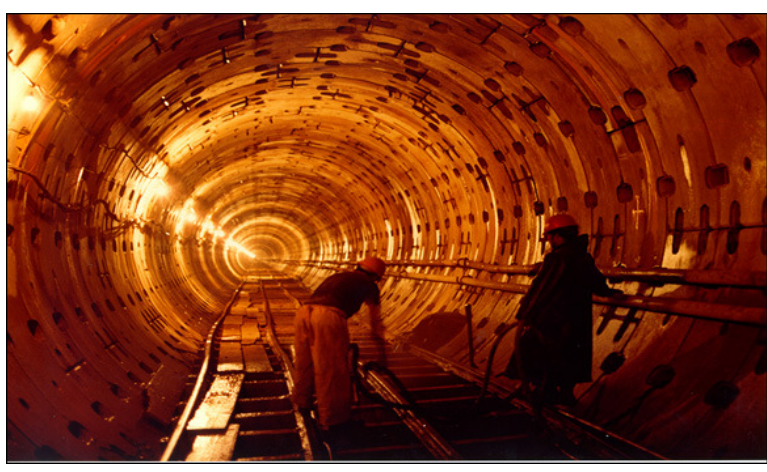

Fotografia 9 - Interceptor Fonte: Sabesp 


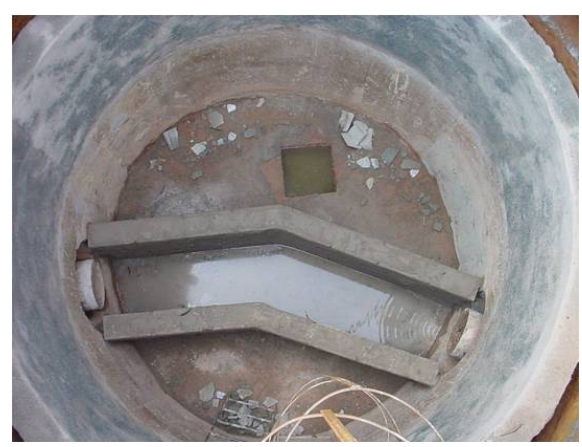

Fotografia 10 - Coletor tronco Fonte: Sabesp

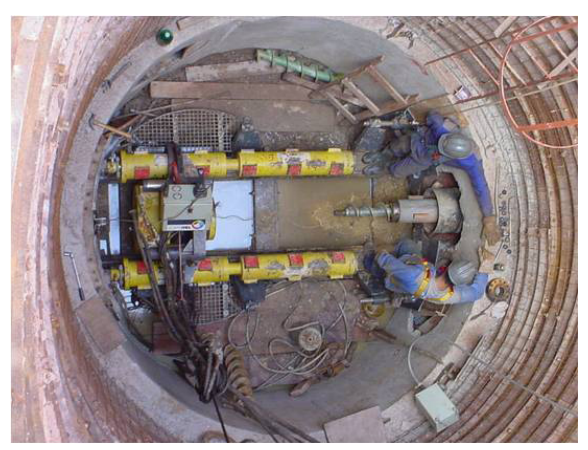

Fotografia 11 - Coletor tronco Fonte: Sabesp

Outra ação importante dessa fase se concentrou no combate a poluição gerada por cerca de 1.250 empresas responsáveis pela emissão de $80 \%$ a $90 \%$ de poluentes industriais despejados na bacia, localizadas na sua maioria (95\%) em locais em áreas com previsão de atendimento por sistemas públicos de esgotos.

Em agosto de 1995, a Fase I do Programa de Despoluição do Rio Tietê foi considerada cumprida, quando 1168 indústrias atendiam aos padrões legais de emissão, havendo uma redução na carga inorgânica de 3,5 toneladas por dia, bem como uma redução de 219 toneladas de DBO por dia, nas emissões das indústrias.

As atividades de controle da poluição industrial tiveram continuidade por intermédio de inspeções e amostragens periódicas e, em dezembro de 1998, verificou-se que $99,1 \%$ das indústrias tinham implantado os controles necessários e verificou-se o atendimento aos padrões legais de emissão, constatando-se a redução de $78 \%$ da carga inorgânica remanescente e da diminuição de cerca de $64 \%$ na emissão remanescente da carga orgânica das indústrias incluídas na Fase I do Programa de Despoluição do Rio Tietê.

Em 2000, iniciou-se a segunda fase, que durou até 2008 com o objetivo principal ampliar e aperfeiçoar o sistema de esgoto implantado na fase anterior. Nessa segunda ação, foram investidos US\$ 500 milhões, focalizando em obras no Rio 
Pinheiros e no entorno da represa Billings, visando sua recuperação para utilização no abastecimento de água da RMSP.

O Rio Pinheiros recebe cerca de 4 mil litros de esgoto por segundo oriundos de cerca de 300 mil residências. Com uma vazão ínfima de $10 \mathrm{~m}^{3}$ por segundo no decorrer de seus $23 \mathrm{~km}$, sua coloração se mostra mais escura que o Rio Tietê e tem suas águas revertidas a Represa Billings, motivo de constantes embates com o Ministério Público e entidades ambientais.

Nessa etapa, foram executados $1208 \mathrm{~km}$ de redes coletoras, 135 mil ligações de esgotos domiciliares, $162 \mathrm{~km}$ de coletor-troncos e interceptores, aumentando a coleta para $84 \%$ e o tratamento para $70 \%$, permitindo que 350 milhões de litros de esgotos deixassem de ser despejados nos rios paulistas. Outro avanço importante foi a conclusão das interligações do sistema Pinheiros, que possibilitou o encaminhamento de cerca de 2.500 litros por segundo de esgoto para a estação de tratamento Barueri melhorada através de diversas obras. Com todo esse investimento, a capacidade das estações de tratamento na RMSP subiu para 16 mil litros por segundo. A Sabesp acredita que devido às características do rio Pinheiros, sua recuperação se dará de forma mais rápida que o próprio Tietê, dependendo, claro, da atuação da prefeitura junto às áreas ocupadas.

A terceira etapa, em negociação, terá vigência até 2015 e serão investidos cerca de US\$ 800 milhões (US\$ 600 milhões do Banco Interamericano de Desenvolvimento e o restante recursos da Sabesp), e tem como objetivo aumentar os índices de coleta e tratamento de esgoto na capital e em 31 cidades. Transportar e tratar o esgoto de tão longe é fundamental porque o Tietê recebe o deságüe de 165 córregos e rios. A empresa vai investir na ampliação de um complexo sistema de coletores e interceptores subterrâneos. Com isso, pretende saltar dos atuais $84 \%$ de esgoto coletado na Grande São Paulo (68\% tratados) para $87 \%$ em 2015, chegando a $100 \%$ em 2018. Para se atingir tais metas, colocam-se necessário lembrar a importância da remoção ou reurbanização das áreas ocupadas irregularmente, nas quais a inexistência de um sistema de saneamento se mostra de forma 
contundente. Para tanto a Sabesp afirma que será atingido 100\% dos locais possíveis de implantação de sistemas.

Para que não ocorra um hiato como o ocorrido entre a segunda e terceira etapa, devido ao cenário financeiro mundial e circunstâncias burocráticas envolvendo os órgãos e as empresas participantes a quarta etapa já se encontra em projeto e tem como perspectiva ser iniciada antes do término da terceira etapa. Seus objetivos se concentram na ampliação da rede de coleta de esgoto, em busca da universalização.

Segundo a Sabesp, ao final da primeira fase do projeto o rio estava morto até na região de Barra Bonita, a cerca de $250 \mathrm{~km}$ da capital. Depois do fim da primeira etapa de limpeza, a mancha de poluição recuou $120 \mathrm{~km}$ e peixes voltaram a aparecer na barragem da cidade, e tem como previsão que em 2011 a mancha recue mais $40 \mathrm{~km}$, até a região de Salto, a $100 \mathrm{~km}$ da capital. A "mancha" de poluição se mostrou importante indicativo de sucesso do programa uma vez que outros índices dependem de outros fatores como o nível de oxigênio no rio, que também sofre influência da poluição difusa existente, isto é, aquela oriunda da sujeira nas ruas, poeira e outros tipos de poluentes existentes na região independentemente da poluição ligada diretamente ao saneamento como Barreto nos informa.

A língua negra que eles chamavam de poluição a língua de poluição, ou a pluma de poluição do Tietê, que eu acho que estava $170 \mathrm{Km}$, agora está em 70, já reduziu bastante. Isso é importante, você trouxe qualidade de vida, o que você mexeu aqui, você pode verificar que foi a mancha de poluição recuar tanto. Evidentemente que ela vai recuar mais. Até uma hora em que ela deixe de existir, essa é a nossa ideia, mas até lá vai ter muita coisa a ser feita, que é uma ocupação de 19 milhões de habitantes, demanda ações de longo prazo de grandes. (informação verbal) ${ }^{2}$

\footnotetext{
${ }^{2}$ Informação obtida por entrevista, Apêndice B, com Douglas Barreto, em 2010
} 


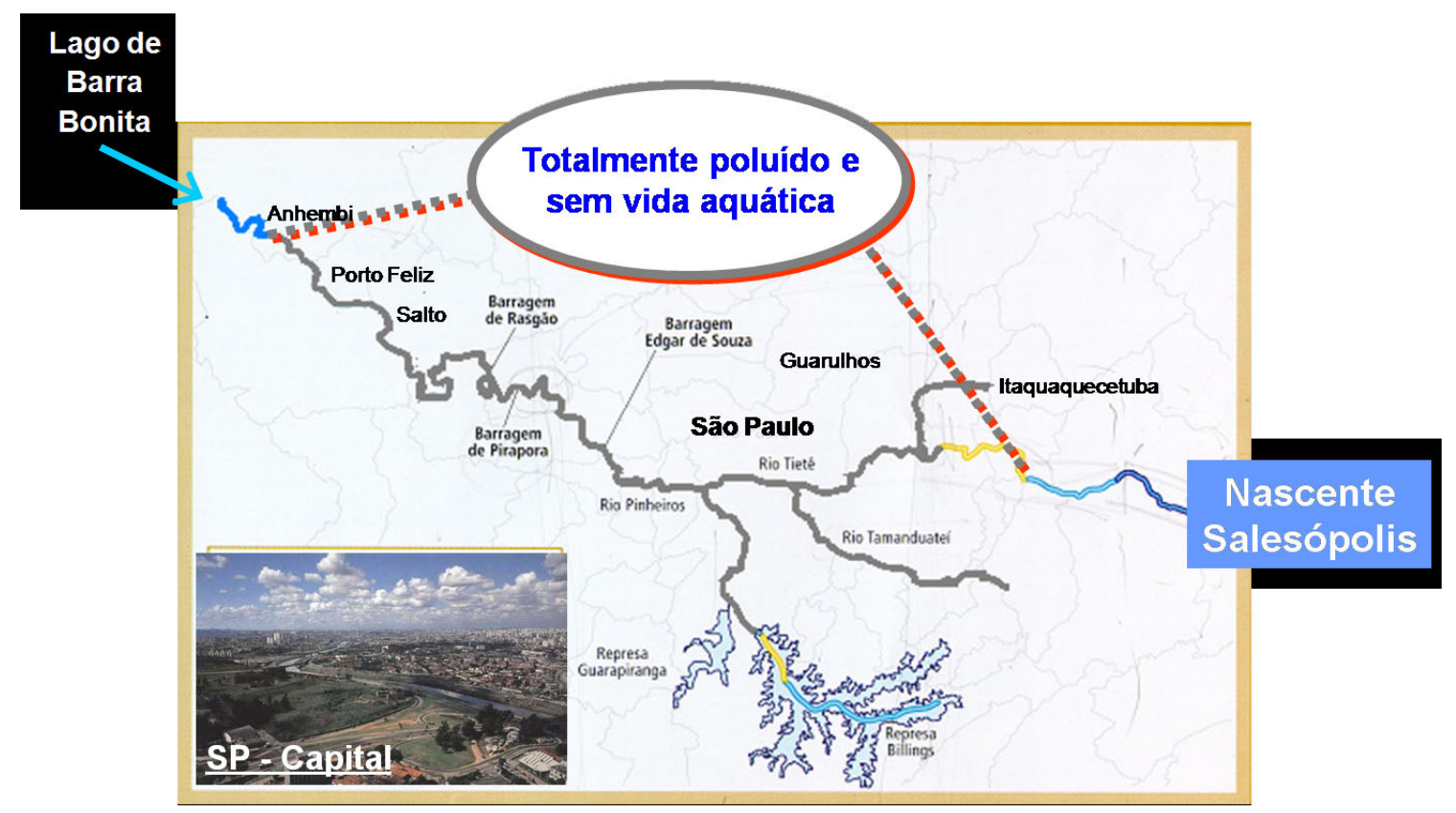

Figura 2 - Mancha de poluição em 1990, antes da primeira etapa do Projeto Tietê Fonte: Sabesp

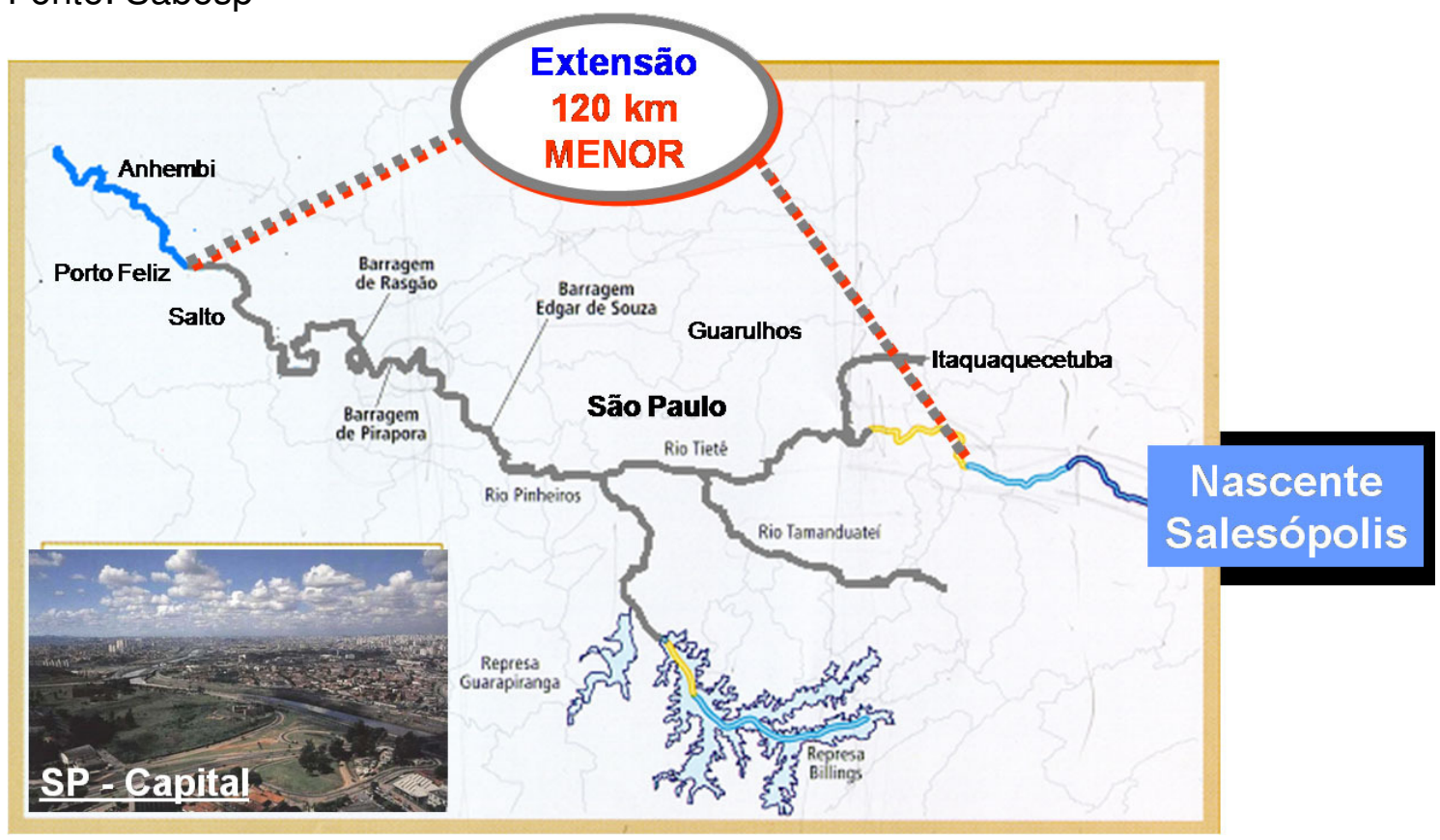

Figura 3 - Mancha de poluição em 2001

Fonte: Sabesp 


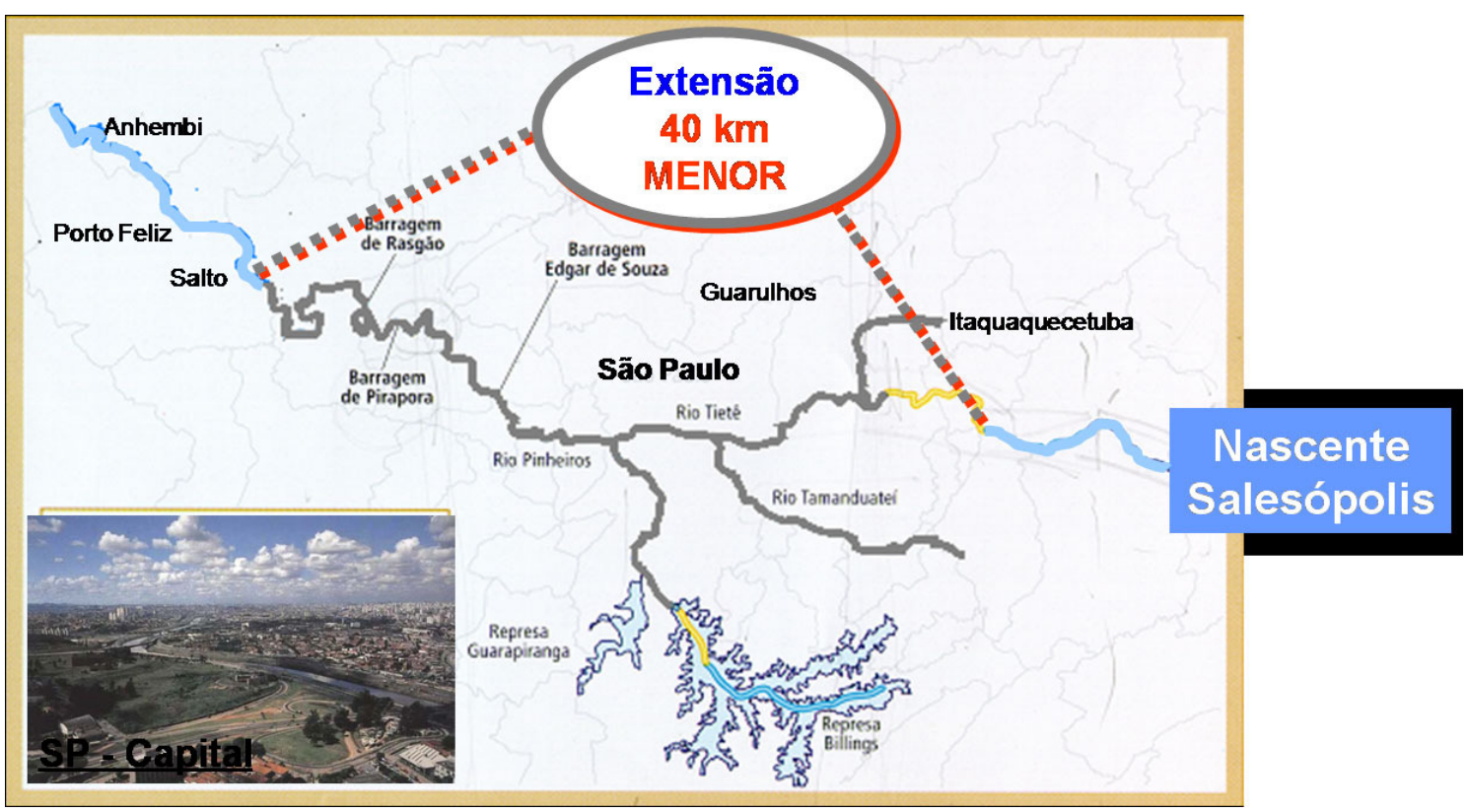

Figura 4 - Mancha de poluição, estimativa a partir de 2008 Fonte: Sabesp

Mesmo com todos os investimentos a despoluição total do Rio Tietê, ou do Rio Pinheiros, ainda se encontra sem previsão. O tratamento $100 \%$ dos esgotos se mostra muito difícil devido ao grande número de ligações clandestinas despejando diretamente nos córregos e rios da região e a necessidade de uma intensa conscientização da população que, por sua vez, não colabora com a limpeza pública e, mesmo havendo infra-estrutura não adere ao sistema a fim de evitar aumento no custo da conta de água. Somente em Outubro de 2008, foram identificadas 18 mil ligações irregulares na Capital. Nesse ponto a importância do projeto Córrego Limpo de mostra de forma clara.

Uma dificuldade do projeto se deve as complicações das obras implantadas, tanto pela questão topológica, pois, o esgoto percorre o percurso até as estações de tratamento por declividade, sendo necessárias 60 pequenas estações elevatórias apenas na região da represa Billings para quando o mesmo atinge os locais mais baixos sejam elevados até os novos coletores até atingir o interceptor e ser encaminhado às estações de tratamento de esgoto (ETE), como pelas obras não 
destrutivas como os coletores, túneis subterrâneos de 2500 milímetros de diâmetro que chegam a percorrer $60 \mathrm{~km}$ entre o local de coleta e o local de tratamento.

Outra dificuldade, apontada pela Sabesp, se deve a não coordenação de projetos e a inexistência de tratamento de esgotos em 8 municípios da RMSP que não fazem parte do sistema da Sabesp. Tal dificuldade não aparece apenas nas questões técnicas de infra-estrutura, mas também se coloca presente nas disputas políticas. Guarulhos, por exemplo, não possui rede de tratamento, não tratando $100 \%$ dos esgotos gerados em sua cidade, despejando todos os dejetos coletados no Rio Cabuçu de Cima, afluente do Tietê. Para a solução dessa questão começaram a ser destinados, em 2009, a cinco pequenas estações que serão construídas, recursos totalizados em $R \$ 249$ milhões do Programa de Aceleração do Crescimento (PAC), do governo federal. A meta é descontaminar $70 \%$ do volume nos próximos 4 anos. Essa questão nos faz reforçar a necessidade de tratar o rio como elemento suprapartidário, interregional, isto é, acima de questões secundárias, disputas políticas, financeiras ou culturais.

Por fim, outro ponto importante a ser avaliado se trata da inevitável comparação com outros rios despoluídos como o Tâmisa (Londres, Inglaterra) e o Sena (Paris, França), por exemplo. Ambos possuem características bem diferentes do brasileiro como a vazão superior e o regime de suas águas.

O projeto de limpeza do Sena durou mais de 70 anos. Também tem que se levar em conta que a população da cidade de São Paulo é de 19 milhões de habitantes, contra os 8 milhões de Paris. Além disso, os dois rios são muito diferentes. A vazão do francês é de 50 mil litros por segundo e o do Tietê é de apenas 34 (CARRELA, jun. 2009).

Carrela também ressalta o aumento proporcional da poluição difusa em comparação a gerada pelos esgotos, chegando a cerca de $30 \%$ do total encontrado no rio. $\mathrm{A}$ partir do programa, o índice de poluentes gerado pelos dejetos diminuiu ao contrário daqueles oriundos da poluição atmosférica e da sujeira urbana, encontrada nas ruas. Esse dado reforça a necessidade da participação da sociedade civil tanto na 
cobrança por medidas, o que resultou no programa, bem como cuidando da limpeza pública, uma vez que todo o lixo descartado nas ruas acaba por ser despejado no Rio Pinheiros e nos seus afluentes e conseqüentemente no Rio Tietê. Tal participação da sociedade também foi lembrada como critica na divulgação do Relatório de Sustentabilidade 2009 da empresa em março de 2010, cobrando uma gestão colaborativa com a presença maciça da população.

[...] poluição difusa, que nada mais é que toda a sujeira jogada ao chão ou que está às ruas, tudo isso acaba chegando ao rio [...] $A$ carga difusa, um assunto muito debatido com CETESB, a fim de se conseguir quantificar. Quanto é isso? Uma coisa é certa, quanto mais esgoto conseguimos tirar do rio, maior é a porcentagem da poluição difusa. Mas já se falou em $20 \%$ a $30 \%$ de poluição difusa que está no rio. É um trabalho que demanda ações culturais (informação verbal) ${ }^{3}$.

O Programa Tietê também está diretamente ligado com a evolução do tratamento de esgoto da RMSP que saltou de 24\% em 1990 para $70 \%$ em 2008 ampliando assim o sistema de coleta e tratamento. Carrela salienta a necessidade de acompanhar o crescimento urbano desorientado da região em direção a periferia, exatamente os locais que mais carecem de infra-estrutura, dificultando e onerando em demasia a operação. Regiões estas onde a ocupação irregular impera, com inúmeras ligações clandestinas, falta de investimentos por muitos anos e com a menor participação da população são fundamentais para o êxito de qualquer programa sócio-ambiental.

São essas ocupações irregulares, esses fundos de vales ocupados, isso é algo que só se consegue tratar junto com a Prefeitura, ela também tem que ter um fôlego para dar condição para se executar as obras, e esse é um dos maiores problemas. [...]

Além disso, o crescimento populacional projetado para a Região metropolitana nos próximos 15 anos aponta um crescimento acentuado nas regiões periféricas e um crescimento negativo na região central, justamente onde já temos nosso sistema de esgotamento consolidado. Toda essa situação impacta tremendamente nos custos dos empreendimentos (informação verbal $)^{4}$.

\footnotetext{
${ }^{3}$ Informação obtida por entrevista, Apêndice B, com Carlos Carrela em 2010

${ }^{4}$ Informação obtida por entrevista, Apêndice B, com Carlos Carrela em 2010
} 
Como o crescimento populacional se apresenta de forma dinâmica e constante, com maior ou menor volume populacional, mas nunca uma estagnação, tais medidas implantadas durante o Projeto Tietê devem se mostrar perenes, isto é, sempre necessárias para se garantir a salubridade dos rios e córregos, mesmo após a sua conquista. Enfim, a rede sempre terá que ser ampliada, para acompanhar o crescimento urbano, e vigiada, para que não ocorram novas instalações clandestinas.

Então não tem como você imaginar que 19 milhões de habitantes agora, vão ficar desgostosos, vão lá pros paraísos nordestinos ou sulistas, ou centro- brasileiro. Não tem 19 milhões, não dá para mudar $10 \%$ da população, uma logística, certo? O que vai acontecer é uma acomodação e uma melhoria, pois à medida que as pessoas vão para outros centros com um pouco melhor qualidade de vida acabam querendo que aqui assim o seja. (informação verbal) $)^{5}$.

É importante ressaltar que outras obras seguem sendo implantadas por outras partes do Governo Estadual independentemente desta encabeçada pela Sabesp. A ampliação da calha do rio com o tratamento de suas margens e seu rebaixamento são obras que visam à diminuição de enchentes na região e não se tratam especificamente de obras visando à recuperação do rio. Bem como atualmente, o programa da estatal paulista também não se caracteriza, por definição da própria empresa, como um programa de despoluição, e sim um projeto estruturante que tem como objetivo a ampliação do sistema de tratamento de esgoto e a recuperação gradativa do rio Tietê. Acredita-se na despoluição, porém em longo prazo, da mesma forma que aconteceu em países da Europa e dos Estados Unidos.

Por outro lado, ao se tratar do rio Tietê com projetos distintos, "separando" a questão enchente, concretando suas margens, do "problema" poluição, o Governo Estadual bem como a companhia paulista fragmentam as ações agindo de forma contrária às necessidades da população e do meio ambiente tratando-se de sustentabilidade urbana. A proteção das margens, bem como dos fundos de vale, com vegetação nativa, parques lineares, isto é, através de uma renaturalização, poder-se-ia ser mais gratificante, tanto na questão de enchente quanto na despoluição do mesmo.

\footnotetext{
${ }^{5}$ Informação obtida por entrevista, Apêndice D, com Douglas Barreto em 2010
} 
Também se mostra como crítica ao projeto a não-participação mais efetiva da Secretaria Estadual da Educação no intuito de minimizar questões como a poluição difusa causada pela ausência de uma conscientização a respeito da limpeza urbana. Programas mais amplos de educação ambiental se mostram fundamental para o êxito de projetos como o do rio Tietê.

O projeto Tietê, portanto, tem se mostrado, na medida do possível, um programa eficiente, porém com resultados realmente visíveis somente num futuro longínquo, dependendo, é claro, de uma inserção mais ampla e sistemática e menos cartesiana.

\section{PROGRAMA VIDA NOVA (MANANCIAIS)}

O Programa Mananciais tem como objetivo melhorar as condições dos reservatórios de água da Região Metropolitana de São Paulo, bem como buscar o desenvolvimento urbano dessa região através de políticas adequadas de gestão das respectivas bacias hidrográficas cujas áreas prioritárias serão sub-bacias Billings e Guarapiranga, bem como as do Alto Tietê - Cabeceiras, do Juqueri-Cantareira e do Alto e Baixo Cotia. 


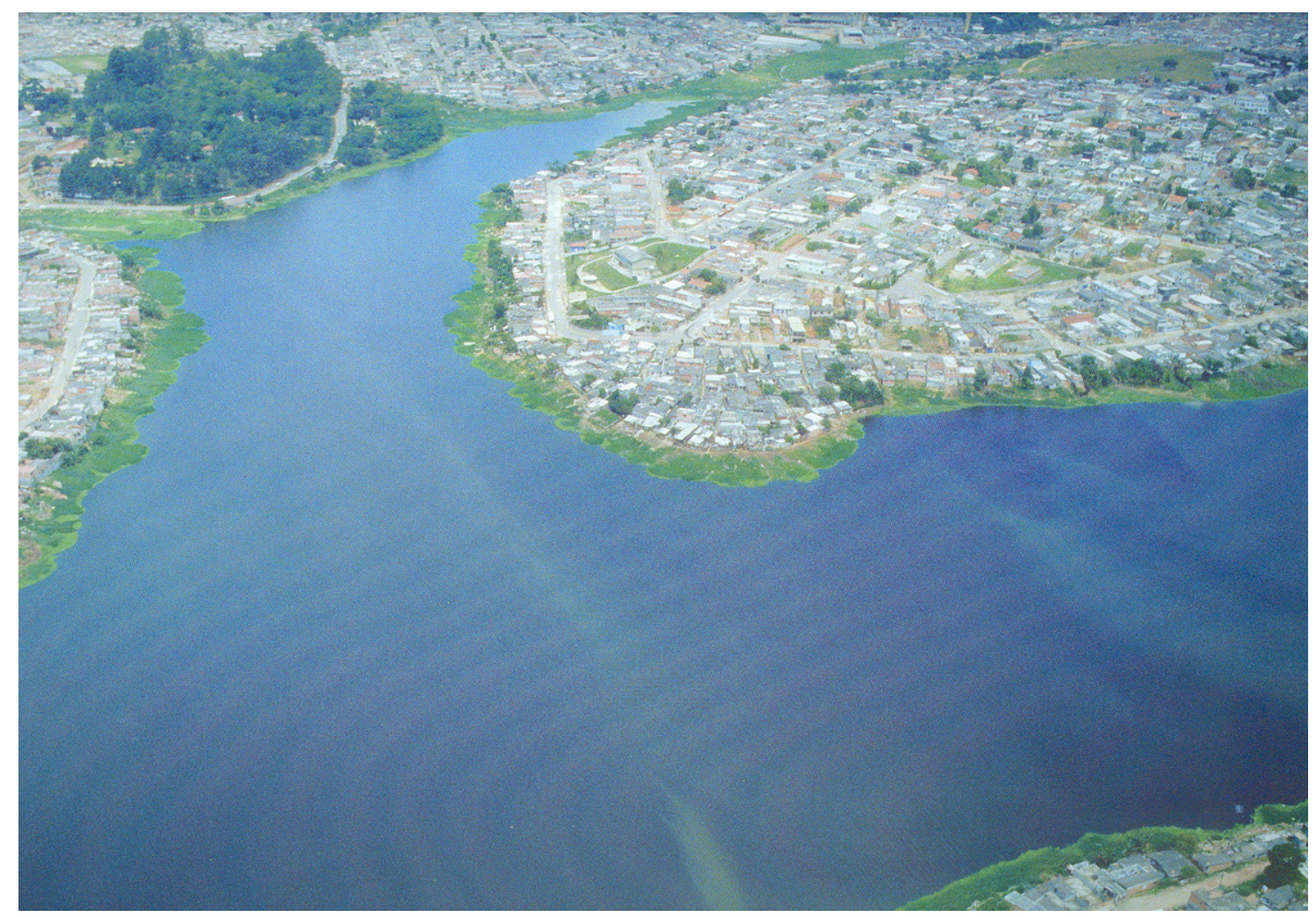

Fotografia 12 - Represa Billings

Fonte: SOLIA (2007).

O programa, antes denominado Projeto Guarapiranga, teve inicio em 1992 atuando estritamente na região da Represa de Guarapiranga. Devido aos avanços o programa foi ampliado à Represa Billings e teve seu nome inicialmente denominado Programa Mananciais e agora assume o nome de Projeto Vida Nova.

O programa tem como principais ações a correção dos principais fatores de poluição dos corpos d água; a melhoria dos padrões de ocupação urbana; melhoria da qualidade de vida da população e atenuação da pobreza urbana; melhoria do padrão de desempenho operacional dos serviços de infra-estrutura pública; a proteção e recuperação ambientais; a contenção da ocupação inadequada e promoção de usos compatíveis com as necessidades ambientais; o desenvolvimento tecnológico e do processo de tratamento da água; a gestão integrada das sub-bacias e estudos técnicos de interesse para esta gestão. 
A Secretaria de Saneamento e Energia vem coordenando as ações da Sabesp, da CDHU e de municípios da região e reúne cerca de $R \$ 1,2$ bilhões de investimentos estaduais, municipais e federais. A maior parte dos recursos será investida na criação de infra-estrutura para coletar o esgoto produzido na região e encaminhá-lo para estações de tratamento, evitando que seja despejado diretamente nos mananciais. O programa inclui ainda ações de proteção de áreas verdes e de urbanização de favelas que beneficiará 45 mil famílias com previsão de término em 2013.

A Companhia de Desenvolvimento Habitacional e Urbano (CDHU) construiu 1.338 unidades habitacionais, urbanizou 29 favelas, construiu 221 casas novas dentro das favelas urbanizadas tendo 2.491 famílias beneficiadas.

E a Prefeitura Municipal de São Paulo (PMSP) construiu 528 unidades habitacionais, reurbanizou 86 favelas, beneficiando 14.868 famílias e construiu 676 casas dentro das favelas urbanizadas, sendo que o projeto como um todo prevê o reassentamento de 250 mil pessoas.

O reassentamento dessas famílias atua em áreas de riscos, ou por questões ambientais ou, até mesmo, por questões técnicas a fim de se viabilizar a instalação de nova infra-estrutura e se coloca como uma das maiores dificuldades do projeto como Sampaio nos diz:

Outro ponto bastante delicado é o reassentamento das famílias. É muito difícil chegar a um morador e informá-lo: "Olha, o senhor precisa sair desse local, a prefeitura pagará um aluguel e, no final das obras, o senhor receberá um novo local para morar". Eles, muitas vezes, não acreditam, desconfiam, não aceitam. Trata-se de 250 mil moradores a serem reassentados em todo o projeto o que torna esse processo ainda mais complicado (informação verbal) ${ }^{6}$.

\footnotetext{
${ }^{6}$ Informação obtida por entrevista, Apêndice C, com Ricardo Corrêa Sampaio em 2010.
} 
A SABESP, uma das participantes, investiu cerca de 94 milhões de dólares, atingindo o total de US\$336 milhões investidos, financiados pelo Banco Internacional de Investimentos tendo como principais ações a construção de 390 quilômetros de redes coletoras, coletor-troncos e emissários nos municípios da bacia, 26.700 novas ligações domiciliares de esgoto com atendimento a 125 mil habitantes, 8.050 ligações domiciliares em redes existentes, totalizando o atendimento a 37 mil pessoas, Duas estações de tratamento de esgotos no município de Embu-Guaçu, 20 estações elevatórias de esgoto e sistema de controle automatizado e centralizado das estações, um sistema de remoção de nutrientes no Córrego, melhoria e aperfeiçoamento tecnológico no tratamento das águas para abastecimento, monitoramento sistemático da qualidade das águas do reservatório Guarapiranga em 13 pontos situados nos tributários, 8 pontos no reservatório e controle da água captada.

A Secretaria de Recursos Hídricos, Saneamento e Obras (SRHSO) teve como ação a transformação de dois lixões em aterros sanitários, nos municípios de Embu e Itapecerica da Serra, a renovação dos equipamentos de limpeza pública dos municípios de Embu, Embu-Guaçu e Itapecerica da Serra e a construção de um galpão de reciclagem de lixo para cooperativa de trabalhadores do Jardim Ângela.

A Secretaria do Meio Ambiente, por sua vez, implantou de seis parques, entre 1995 e 1999, totalizando uma área de 685 hectares. Dentre eles, o Parque Ecológico Guarapiranga, próximo ao Jardim Ângela. 


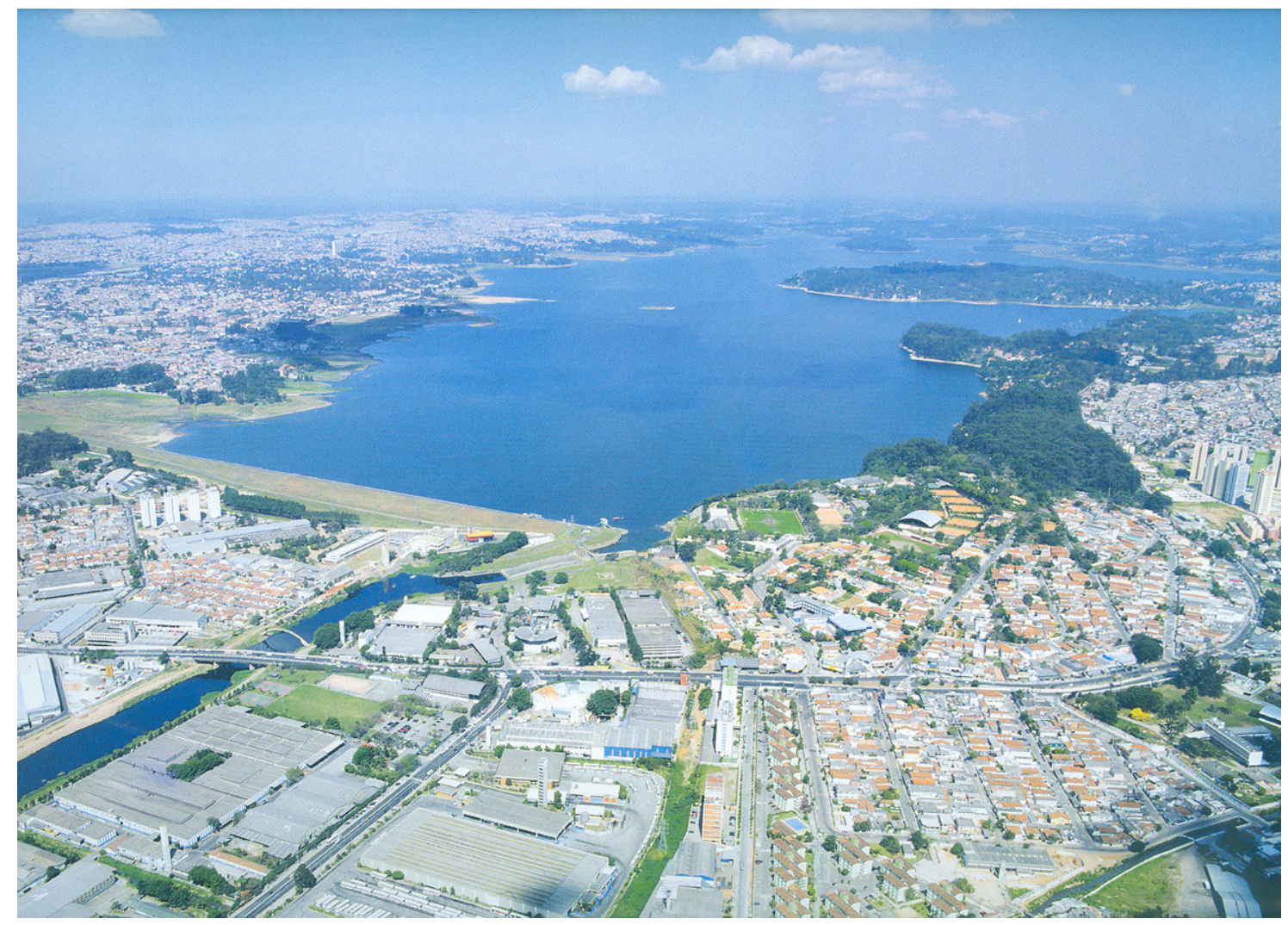

Fotografia 13 - Represa Guarapiranga Fonte: SOLIA (2007).

Para recuperar o entorno através da revitalização urbana da região, a prefeitura e a Sabesp atuam com diversos agentes. Uma das dificuldades apontadas por Sampaio se trata exatamente da relação complexa entre esses atuantes envolvidos no projeto, incluindo prefeituras vizinhas, órgãos municipais, estaduais, federais e em alguns momentos internacionais.

Trata-se de 2,5 milhões de habitantes na região, instalados há mais de 20 anos no local. Cada Secretaria, cada agente, possui uma preocupação especifica e aliar todos os interesses, demonstrar à comunidade os projetos e seus ganhos, e convencê-los a uma participação mais efetiva é uma tarefa bastante complexa (informação verbal) ${ }^{7}$.

Outro fator complicador no projeto era a legislação local. Antes toda a região no entorno das represas era denominada como zona rural. Tal situação levava a

\footnotetext{
${ }^{7}$ Informação obtida por entrevista, Apêndice C, com Ricardo Corrêa Sampaio em 2010.
} 
prefeitura a não investir em infra-estrutura, nem habitações populares, fechando os olhos às ocupações irregulares que invadiam as margens das represas. A flexibilização da legislação permitiu as intervenções urbanas como novos assentamentos, instalação de infra-estrutura, água, luz, esgoto e equipamentos públicos como escolas, parques e afins e uma atuação mais presente dos órgãos competentes, como se reintegrasse a região à cidade legal, pelo menos uma tentativa.

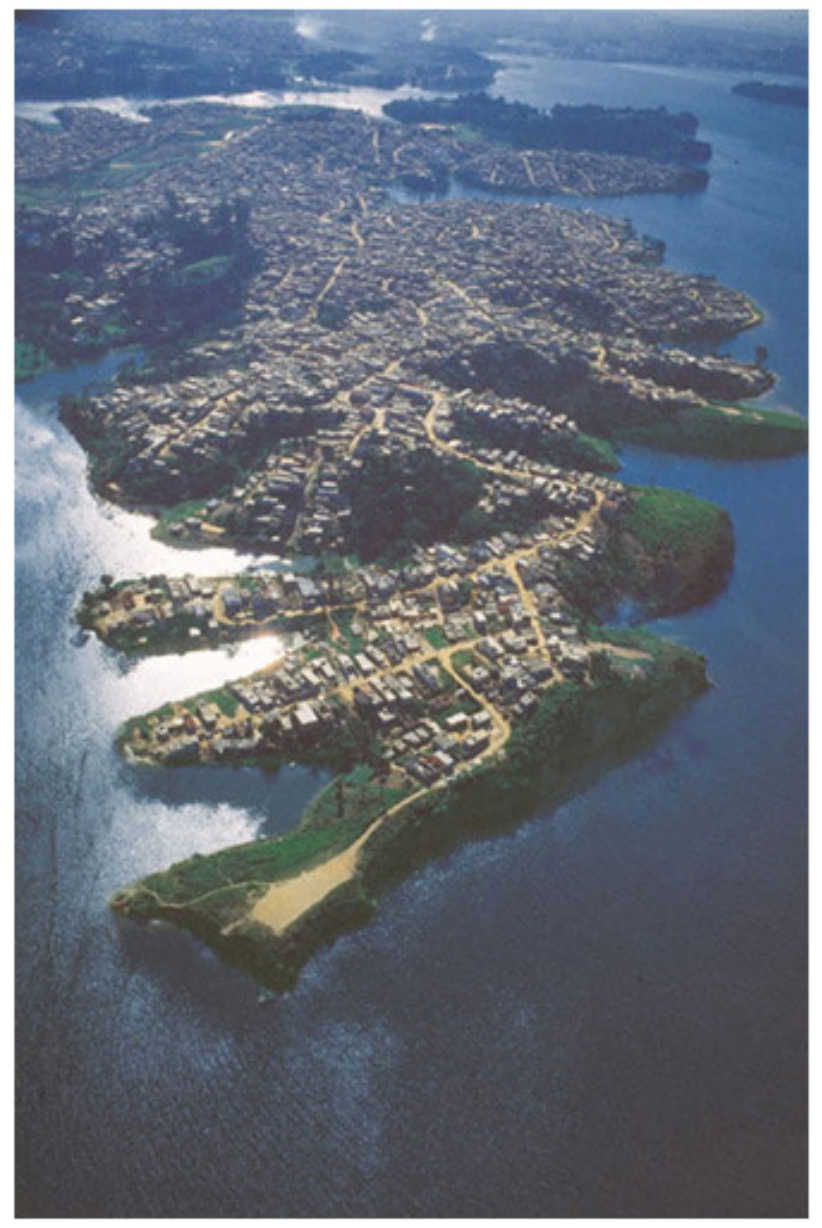

Fotografia 14 - Cantinho do Céu

Fonte: Sabesp

Deve se ressaltar o fato desse programa da Sabesp ir além da tecnologia a fim de se preservar a água ou o meio ambiente de forma geral, mas também se trata de questões sociais, culturais e urbanísticas. 
O Projeto acaba, portanto, por atuar na defesa das principais fontes de recurso hídrico da RMSP, as represas do Guarapiranga e da Billings. Por se tratar de uma região fortemente adensada e de forma irregular com população estimada de 2,5 milhões de habitantes, uma cidade, as ações devem ser amplas, sistêmicas e em longo prazo. O Projeto Vida Nova procura apresentar essa visão generalizada atuando desde questões estruturais, urbanas, sócio-educacionais e ambientais na

tentativa de reintegrar essa região de volta a RMSP. É necessário, porém, reiterar a necessidade de incluí-la em planos diretores futuros e uma constante fiscalização a fim de evitar novas invasões. Pelo contrário, se possível estar sempre presente a fim de se investir no recuo da mancha urbana, cada vez mais para longe das margens das águas da represa.

\section{CÓRREGO LIMPO}

O programa Córrego Limpo é resultado de uma parceria entre o Governo do Estado, por meio da Sabesp, e a Prefeitura de São Paulo, em 2007, cujo objetivo é reverter a situação dos córregos na cidade de São Paulo. O cronograma total prevê que 300 córregos estejam despoluídos num período de dez anos, sendo 100 até $2010 . \mathrm{Na}$ primeira fase finalizada em Março de 2009, foram investidos $R \$ 200$ milhões em 42 córregos, sendo que destes, 16 foram despoluídos em 2008, beneficiando 2,4 milhões de pessoas e uma área de $204 \mathrm{~km} 2$, ou seja, 25\% da população paulistana. $\mathrm{Na}$ segunda fase, serão mais $\mathrm{R} \$ 241$ milhões a serem investidos em 58 córregos espalhados pelas cinco regiões da cidade. Dos $\mathrm{R} \$ 441$ milhões investidos nesse período $\mathrm{R} \$ 311$ milhões estarão a cargo da Sabesp.

O Programa prevê também o aprimoramento dos sistemas de coleta de esgotos. Para isso, uma força-tarefa da Sabesp executa obras para ampliar as redes existentes, eliminar os lançamentos clandestinos de esgotos nos córregos e galerias de águas pluviais e também melhorar os sistemas de envio de esgotos às estações de tratamento. Os empreendimentos possibilitarão, ainda, o aumento do número de 
residências conectadas às redes da Sabesp, o que significa mais esgotos coletados e tratados.

À Prefeitura cabe a manutenção das margens e dos leitos dos córregos, bem como a remoção de imóveis nos fundos de vale que impeçam a passagem das tubulações principais de esgotamento sanitário. Nesse trabalho conjunto, as Subprefeituras irão intensificar a atuação junto aos responsáveis para regularizar a ligação de esgotos. Com o trabalho desenvolvido pelas Secretarias Municipais de Coordenação das Subprefeituras, Verde e Meio Ambiente e Habitação, em conjunto com a Secretaria de Estado de Saneamento e Energia e a Sabesp, mais de 500 litros de esgoto por segundo deixaram de ser lançados aos córregos, segundo a coordenadoria do programa. Conseqüentemente, os Rios Tietê e Pinheiros deixaram de receber parte das cargas de esgoto que poluem seus leitos.

No Córrego Cruzeiro do Sul Mirim, por exemplo, o índice de poluição, segundo o programa, foi reduzido de $98 \%$ com o fim da descarga de 800 mil litros de esgoto diários no curso d água. A favela que ficava nas margens do córrego foi substituída por um parque, com áreas de lazer e paisagismo e calçadas com piso permeável. As ligações clandestinas de esgoto das vizinhanças foram fechadas e o entulho acumulado no leito e nas margens foi recolhido.

A Prefeitura calcula que cerca de 30 mil pessoas foram beneficiadas com o programa e 230 famílias que habitavam os barracos da favela do local foram removidas. Delas, 96 retornaram a região, abrigadas com bolsa-aluguel fornecida pela prefeitura durante as obras. Hoje moram em apartamentos construídos pela Secretaria da Habitação. As demais receberam a chamada verba de apoio habitacional de $\mathrm{R} \$ 5$ mil em troca da habitação irregular 
Além de ser encarregada da limpeza dos córregos, contenção e manutenção de margens, verificação de interferências em bocas de lobo e galerias e atender as famílias que precisam ser removidas, a prefeitura é responsável pela fiscalização das ligações de esgoto. Por sua vez, a Sabesp cuida do prolongamento das redes de esgoto, da ampliação das ligações domiciliares e da manutenção e monitoramento das redes.

Para manter limpos os córregos já despoluídos e recuperados, o poder público conta com a colaboração dos moradores. Prefeitura e Estado incentivam as comunidades a criar novos hábitos, para evitar o despejo de lixo nas ruas e encostas. Informações sobre a correta utilização do sistema de coleta de esgoto e de galerias de águas pluviais também são repassadas aos moradores, pois, como Massone nos diz, a participação da população é fundamental para o sucesso do projeto.

Uma das coisas que nós percebemos no trabalho de despoluição do Guarapiranga em 1992, e fez-se isso num relatório pela unidade de gerenciamento na época. É que grande parte do trabalho foi perdida lá porque o trabalho de educação ambiental não foi desenvolvido da forma como deveria ter sido. Na verdade foi um aprendizado e hoje a gente tem esse cuidado de estar disparando algumas ações dentro da Sabesp para poder fazer um trabalho de educação ambiental, um engajamento da população que vive entorno do córrego, a começar se envolver mais e procurar preservar e conservar o trabalho que a Sabesp e a prefeitura vem fazendo hoje (informação verbal) ${ }^{8}$.

O programa também inclui um projeto de Educação Ambiental junto à população para conscientizar as pessoas sobre a importância de não depositar lixo e entulho nas ruas ou nos córregos e se conectar a rede de esgotos e cuidar das instalações residenciais colaborando assim para a eficácia tanto do programa Córrego Limpo e do Projeto Tietê a fim de minimizar o impacto de ligações clandestinas, um problema crônico desse e de outros projetos. Adicionalmente, oito regiões próximas a córregos

\footnotetext{
${ }^{8}$ Informação obtida por entrevista, Apêndice F, com Gilmar Massone em 2010.
} 
serão transformadas em parques lineares proporcionando mais saúde e lazer as pessoas, como no projeto mananciais.

Muitos córregos, mesmo após o recebimento do tratamento, apresentaram problemas de enchentes. A mudança das margens, bem como da configuração natural do leito, fez com que a vazão do volume de água transportado diminuísse principalmente após sua "canalização" e o programa não prevê apenas com suas interferências consertar essa falha antiga. Acredita-se que o problema de macrodrenagem da RMSP, a desgulamentação do uso e ocupação do solo bem como a indevida ocupação dos fundos de vale gerando uma impermeabilização desvairada não pode ser corrigido com ações pontuais. No primeiro momento, o programa tem como foco a despoluição desses córregos colaborando para a recuperação das Bacias de forma geral, incluindo os Rios Pinheiros e Tietê.

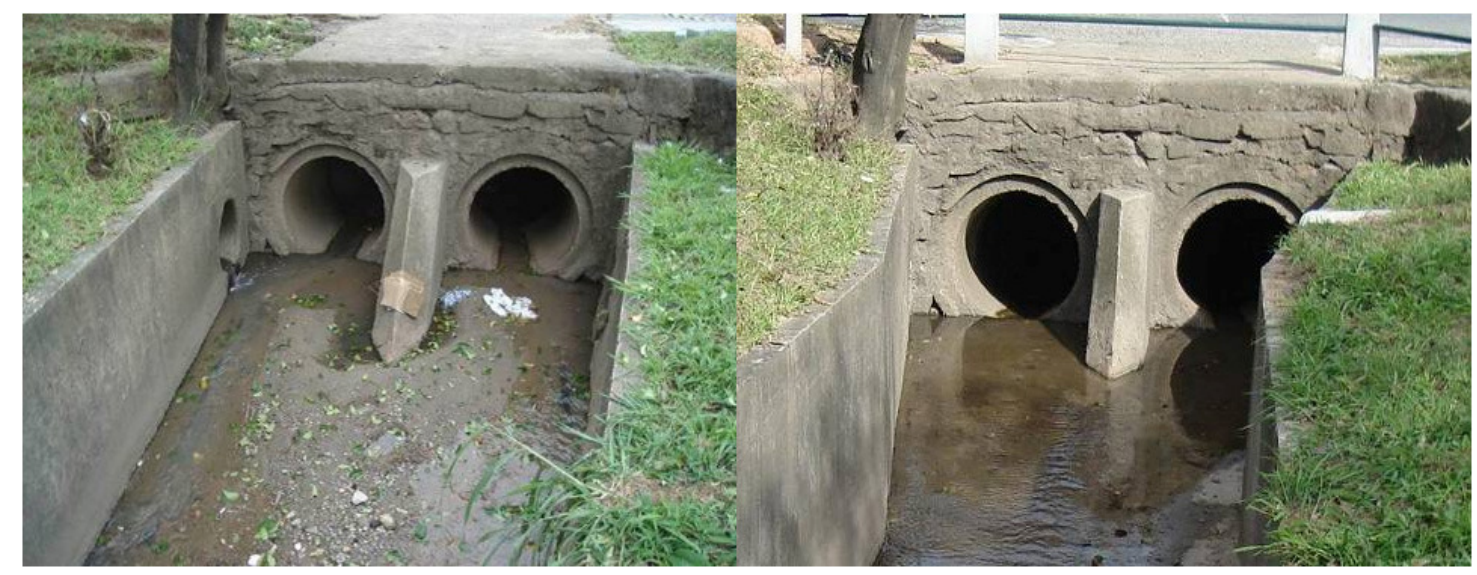

Fotografia 15 - Córrego Charles de Gaulle Fonte: Gilmar Massone - Sabesp

Nesse ponto, a necessidade de se rever a ocupação das margens dos córregos se mostra fundamental para o sucesso de projetos como esse, uma vez que o uso adequado das várzeas, como, por exemplo, com parques lineares, colaboraria para evitar essas situações de enchentes e da própria poluição dos córregos e rios da região. 
Por outro lado, ao se recuperar as margens dos córregos com novos usos, e com uma nova imagem, a população do local assume outra postura perante o leito reurbanizado, diminuindo o descarte de lixo e passando do papel de poluidor ao papel de "fiscal do meio ambiente" colaborando para sua manutenção, como se somente através da nova configuração já se obtivesse uma nova educação ambiental.

Os córregos recuperados, segundo Gilmar Massone, analista de sistema do saneamento, deixaram de ser o fundo das casas, ignorados pelos moradores, para se tornar quintal, espaço de convívio, de lazer colaborando para a maior participação dos mesmos como fiscais do programa.

É bastante interessante, porque hoje a gente percebe que os córregos que são melhor cuidados, em que a população se envolve mais com eles são os córregos em que as casas estão de frente para esses córregos. Porque normalmente a população constrói as casas de costas para o córrego. Porque ali corre esgoto. Mas nos córregos em que corria esgoto e as casa eram obrigadas a serem construídos para frente desse córrego, hoje eles cuidam muito mais do córrego do que o pessoal que tem os córregos perto das casas. E hoje é interessante, por que, normalmente hoje ao longo desses córregos a prefeitura tem construído pistas de correr, alguns parquinhos com uns brinquedos, algumas mesinhas pros aposentados jogarem damas, xadrez, essas coisas (informação verbal) ${ }^{9}$.

Massone aponta como futuro do programa, a exemplo de outros países como França e Alemanha, a renaturalização dos córregos. Hoje, a recuperação, promovida pelo programa Córrego Limpo, recupera os leitos através da "concretagem" das margens, isto é, com uma canalização artificial, e a renaturalização se baseia no retorno dos córregos ao seu formato natural, sem barreiras de concreto ou muros de arrimo tipo gabião. Porém, para que haja esse passo, a população deve se mostrar preparada culturalmente para assumir suas responsabilidades para com o meio em que vivem. Nos países citados, a renaturalização surgiu de uma demanda da própria sociedade e não como uma ação imposta por empresas ou governos.

\footnotetext{
${ }^{9}$ Informação obtida por entrevista, Apêndice F, com Gilmar Massone em 2010.
} 


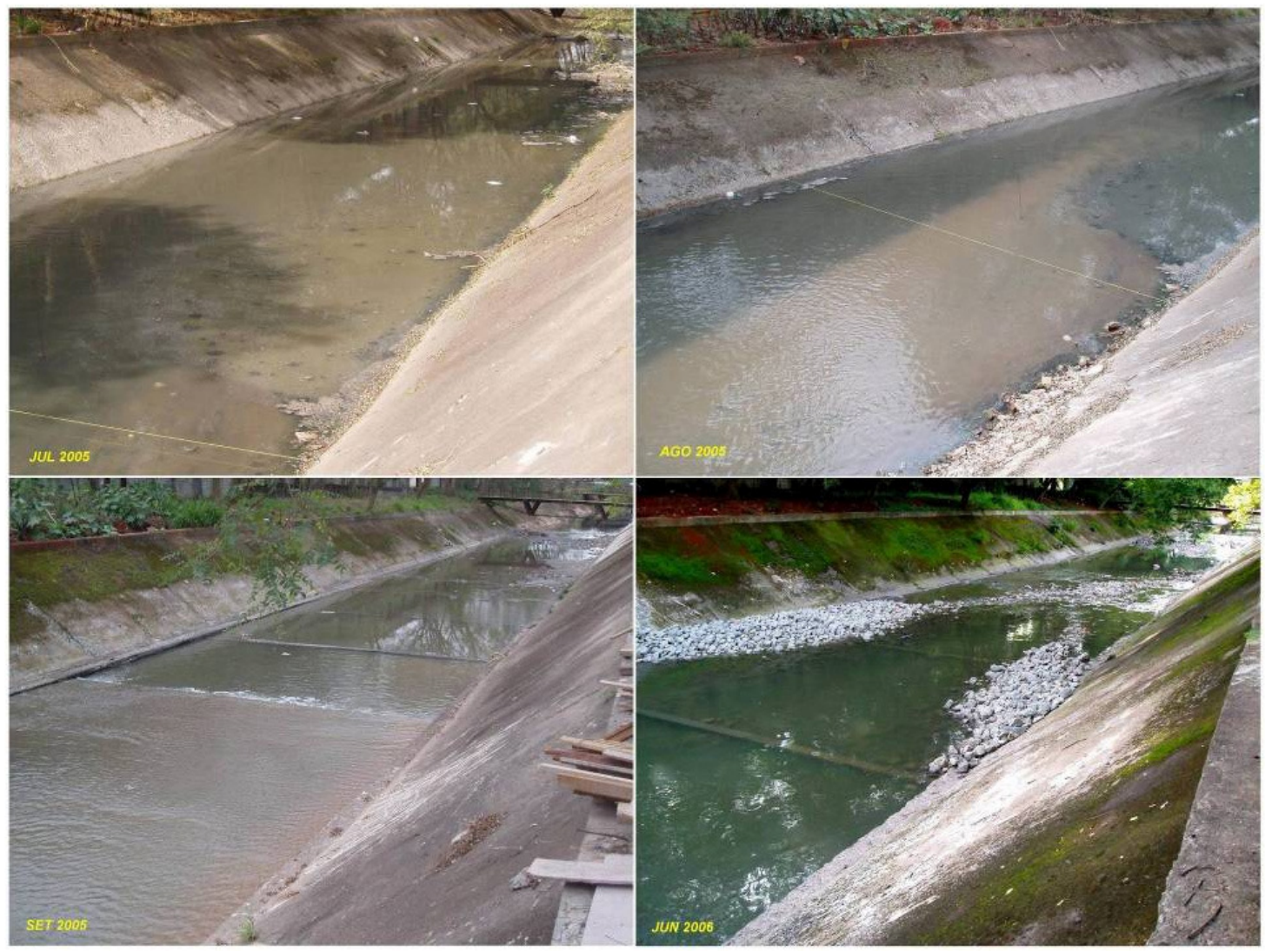

Fotografia 16 - Córrego Carajás/ Carandiru

Fonte: Gilmar Massone - Sabesp

O programa tem como horizonte estar concluído até 2018, porém tais metas dependem do assentamento das famílias em ocupações irregulares, problema que se colocou como uma das maiores dificuldades do projeto, bem como da continuidade de governo e financiamento disponível. Mesmo com as metas atingidas, Massone ressalta a necessidade de monitoramento constante dos córregos, uma vez que a poluição pode retornar a qualquer momento quer seja devido a rompimentos na rede existente ou pelo surgimento de novas ligações clandestinas. Ele cita o exemplo do lago do Parque Ibirapuera, despoluído num determinado momento e após uma década em nova vistoria foram encontrados altos índices de poluição. Na pesquisa da causa, encontrou-se o surgimento de favela a cerca de 5 quilômetros do local.

É que assim, a partir do momento que você vai fazer a despoluição do córrego, você tem que constantemente verificar se ele continua despoluído ou não. Então existem monitoramentos dos córregos que estão em despoluição, que a gente já despoluiu e que se encontra em manutenção. A gente faz a coleta mensalmente, faz a análise dessa coleta e verifica qual o grau de poluição. [...] Foi um problema 
de poluição que veio de uma favela que estava sendo instalada na cabeceira da bacia, perto da Domingos de Moraes. Ficou conhecida como favela do INSS. Era a favela no INSS. O terreno ali era do INSS. E naquela época, nós fomos lá, fizemos as redes dentro da favela, fizemos a captação de esgoto, só que o esgoto estava sendo lançado na galeria, e aquela galeria é um dos afluentes do lago do Ibirapuera. (informação verbal) ${ }^{10}$.

À exemplo dos demais programas, o Córrego Limpo também necessita do amparo de projetos educacionais amplos, de maneira que conscientizem a população para as questões ambientais do século XXI. O projeto simples e puramente desenvolvido pela companhia paulista de saneamento se mostra fadado ao fracasso caso não seja inserido num programa amplo de educação e, mesmo assim, seus resultados serão apurados somente na segunda metade do século.

\section{PURA - PROGRAMA DE USO RACIONAL DA ÁGUA}

O Programa de Uso Racional da Água (PURA) se apresenta como uma das medidas adotadas pela Sabesp voltada para o controle de demanda da Água.

Criado em 1996, como uma alternativa a necessidade de racionamento de água através do combate ao desperdício, o PURA tem como principal objetivo atuar na demanda de consumo de água, incentivando o Uso Racional por meio de ações tecnológicas, normatizando o setor e difundindo medidas para a conscientização dos clientes a fim de enfrentar a escassez de recursos hídricos e seus desperdícios.

O programa atua, em três pilares que são: Tecnologia, que busca novos equipamentos, visando sempre o nosso foco que é a economia de água; Normativa, que é onde de tudo o que é inventado, criado, seguem regras, além de mercado, também... a parte Educacional que é a conscientização. (informação verbal) ${ }^{11}$.

\footnotetext{
${ }^{10}$ Informação obtida por entrevista, Apêndice F, com Gilmar Massone em 2010.

${ }^{11}$ Informação obtida por entrevista, Apêndice A, com Agnaldo Ruivo em 2010
} 
Isto é, o PURA atua desde tecnologicamente, quando se estudam soluções a serem implantadas e estimulando o desenvolvimento de novos equipamentos junto aos fabricantes, normativamente, criando normas técnicas junto a ABNT, a fim de regulamentar equipamentos, instalações e afins, e educacionalmente, desenvolvendo campanhas educativas para explanar 0 uso adequado das instalações e boas práticas de economia de água, tanto ao usuário final como para formar agentes multiplicadores

Numa primeira fase, montou-se a estrutura e depois, foram desenvolvidos os projetos-pilotos para criação da metodologia de ação, em hospitais, escolas estaduais, cozinhas industriais, prédios comerciais e condomínios, entre outros.

O programa tem se caracterizado por soluções "micro", isto é, voltado para reduzir o consumo em áreas prediais. Portanto, o primeiro passo se trata em escolher os locais de ação com grande potencial de redução, como edifícios públicos, escolares, institucionais e afins. Para identificar as melhores ações de redução do consumo de água é necessário avaliar o potencial de redução do consumo que o imóvel apresenta. Quanto maior o consumo, maiores as alternativas para redução.

A partir da definição do local de ação o programa se divide em 5 etapas:

Etapa 1 - Diagnóstico geral.

Etapa 2 - Redução de perdas físicas.

Etapa 3 - Redução de consumo nos pontos de utilização.

Etapa 4 - Caracterização dos hábitos e racionalização das atividades que consomem água.

Etapa 5 - Divulgação, campanhas de conscientização e treinamentos.

A Etapa 1 se caracteriza pela análise global do local a ser implantado. Nesse momento, inicia-se a fase de diagnóstico, quando a Sabesp e ou seus parceiros 
analisam os locais de ação tanto estruturalmente como do ponto de vista funcional a partir de uma serie de estudos. Verifica-se, por exemplo, a média de consumo, as instalações físicas, os hábitos da população local, as reais necessidades, etc., para depois, ainda nessa fase, analisar se os parâmetros condizem com o uso do edifício, e, por fim, definir quais ações deverão ser tomadas. Essa fase se mostra extremamente importante, pois será o momento de escolher os devidos equipamentos, as tecnologias mais apropriadas bem como definir onde e como serão tomadas as medidas de redução de consumo.

Muitas tecnologias foram desenvolvidas ou importadas a partir da necessidade do programa, pois ora não existiam no país ora não se mostravam adequadas as problemáticas existentes. Nesses casos, a Sabesp estimulava os fabricantes a desenvolverem soluções economizadoras como torneiras de acionamento automático, válvulas de restrição de vazão (VDR), bacias sanitárias econômicas, duchas, válvulas de acionamento economizadoras, sensores de medição, etc., criando assim nichos de mercado, hoje amplamente explorados por fabricantes e prestadores de serviços.

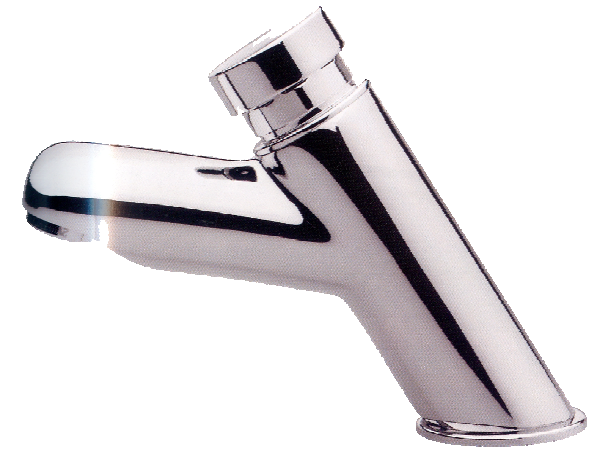

Fotografia 17- Torneira para lavatório de mesa Fonte: DOCOLMATIC

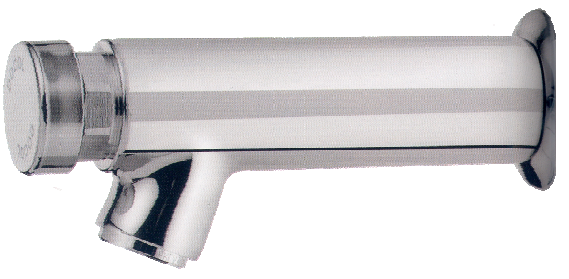

Fotografia 18 - Torneira para lavatório de parede Fonte: DOCOLMATIC 


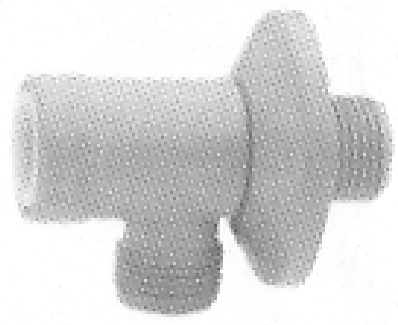

Fotografia 19 - Registro regulador de vazão

Fonte: DOCOLMATIC

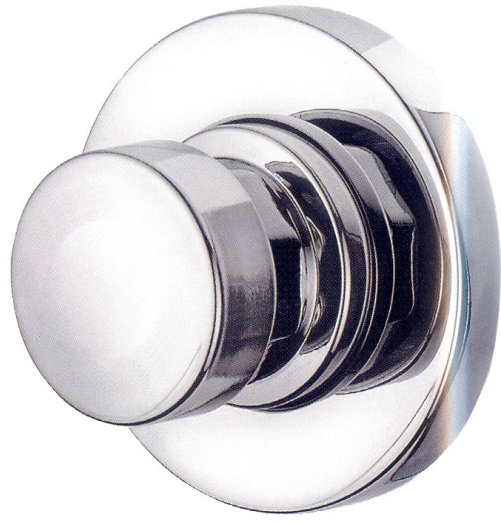

Fotografia 21 - Válvula para água fria ou para válvula pré-misturada - chuveiro Fonte: DOCOLMATIC

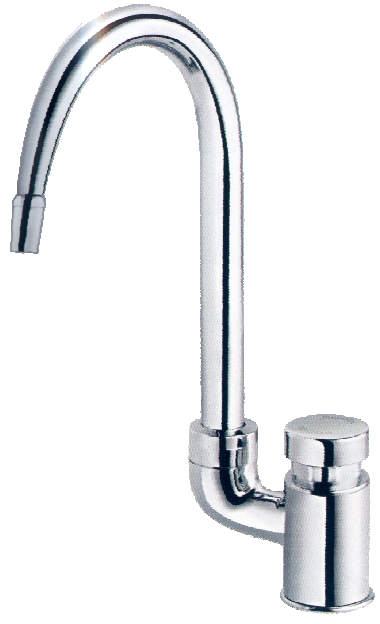

Fotografia 20 - Torneira para lavatório de mesa Fonte: DOCOLMATIC

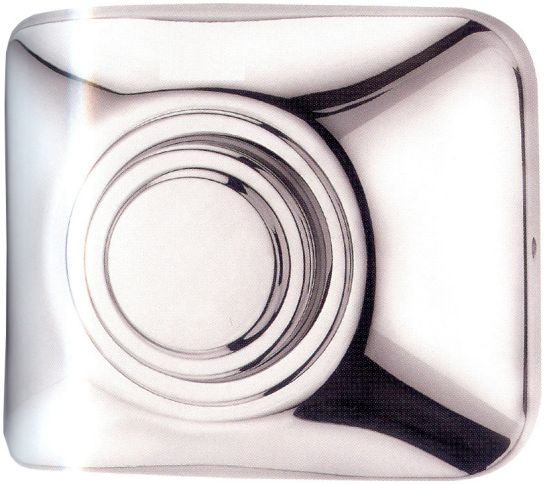

Fotografia 22 - Acabamento de descarga antivandalismo Fonte: DOCOLMATIC 


\begin{tabular}{|c|c|c|c|c|}
\hline $\begin{array}{l}\text { Equipamento } \\
\text { Convencional }\end{array}$ & Consumo & $\begin{array}{l}\text { Equipamento } \\
\text { Economizador }\end{array}$ & Consumo & Economia \\
\hline $\begin{array}{c}\text { Bacia com caixa } \\
\text { acoplada }\end{array}$ & $\begin{array}{c}12 \\
\text { litros/descarga }\end{array}$ & Bacia VDR & $\begin{array}{c}6 \\
\text { litros/descarga }\end{array}$ & $50 \%$ \\
\hline $\begin{array}{l}\text { Bacia com válvula } \\
\text { bem regulada }\end{array}$ & $\begin{array}{c}10 \\
\text { litros/descarga }\end{array}$ & Bacia VDR & $\begin{array}{c}6 \\
\text { litros/descarga }\end{array}$ & $40 \%$ \\
\hline $\begin{array}{c}\text { Ducha (água } \\
\text { quente/fria) - até } 6 \\
\text { mca }\end{array}$ & 0,19 litros/seg. & $\begin{array}{l}\text { Restritor de } \\
\text { vazão } 8 \\
\text { litros/min. }\end{array}$ & 0,13 litros/seg. & $32 \%$ \\
\hline $\begin{array}{c}\text { Ducha (água } \\
\text { quente/fria) - } 15 \text { a } \\
20 \text { mca }\end{array}$ & 0,34 litros/seg. & $\begin{array}{l}\text { Restritor de } \\
\text { vazão } 8 \\
\text { litros/min. }\end{array}$ & 0,13 litros/seg. & $62 \%$ \\
\hline $\begin{array}{c}\text { Ducha (água } \\
\text { quente/fria) - } 15 \text { a } \\
20 \text { mca }\end{array}$ & 0,34 litros/seg. & $\begin{array}{l}\text { Restritor de } \\
\text { vazão } 12 \\
\text { litros/min. }\end{array}$ & 0,20 litros/seg. & $41 \%$ \\
\hline $\begin{array}{l}\text { Torneira de pia - até } \\
6 \mathrm{mca}\end{array}$ & 0,23 litros/seg. & $\begin{array}{l}\text { Arejador vazão } \\
\text { se (6 litros/min.) }\end{array}$ & 0,10 litros/seg. & $57 \%$ \\
\hline $\begin{array}{l}\text { Torneira de pia - } 15 \\
\text { a } 20 \mathrm{mca}\end{array}$ & 0,42 litros/seg. & $\begin{array}{l}\text { Arejador vazão } \\
\text { (6 litros/min.) }\end{array}$ & 0,10 litros/seg. & $76 \%$ \\
\hline $\begin{array}{c}\text { Torneira uso } \\
\text { geral/tanque - até } 6 \\
\text { mca }\end{array}$ & 0,26 litros/seg. & $\begin{array}{l}\text { Regulador de } \\
\text { vazão }\end{array}$ & 0,13 litros/seg. & $50 \%$ \\
\hline $\begin{array}{c}\text { Torneira uso } \\
\text { geral/tanque - } 15 \text { a } \\
20 \text { mca }\end{array}$ & 0,42 litros/seg. & $\begin{array}{l}\text { Regulador de } \\
\text { vazão }\end{array}$ & 0,21 litros/seg. & $50 \%$ \\
\hline $\begin{array}{c}\text { Torneira uso } \\
\text { geral/tanque - até } 6 \\
\text { mca }\end{array}$ & 0,26 litros/seg. & $\begin{array}{l}\text { Restritor de } \\
\text { vazão }\end{array}$ & 0,10 litros/seg. & $62 \%$ \\
\hline $\begin{array}{c}\text { Torneira uso } \\
\text { geral/tanque - } 15 \text { a } \\
20 \text { mca }\end{array}$ & 0,42 litros/seg. & $\begin{array}{l}\text { Restritor de } \\
\text { vazão }\end{array}$ & 0,10 litros/seg. & $76 \%$ \\
\hline $\begin{array}{l}\text { Torneira de jardim - } \\
\quad 40 \text { a } 50 \mathrm{mca}\end{array}$ & 0,66 litros/seg. & $\begin{array}{l}\text { Regulador de } \\
\text { vazão }\end{array}$ & 0,33 litros/seg. & $50 \%$ \\
\hline Mictório & 2 litros/uso & $\begin{array}{c}\text { Válvula } \\
\text { automática }\end{array}$ & 1 litro/seg. & $50 \%$ \\
\hline
\end{tabular}

Quadro 1 - Quadro comparativo de equipamentos economizadores * Torneira de Pia - abertura 1 volta * Ducha - abertura total *- O regulador de vazão permite o usuário regular de acordo com sua necessidade * Fonte: Relatório Mensal 3 Projeto de Pesquisa Escola Politécnica / USPxSABESP Junho/96 e informações técnicas da ASFAMAS. 
A Etapa 2, por sua vez, se resume na varredura do local a fim de se verificar a existência ou não de perdas, isto é, de vazamentos.

Conforme Associação Internacional de Suprimento de Água, as perdas das concessionárias atingem entre $20 \%$ e $30 \%$ da produção, principalmente por vazamentos. No Brasil a situação não se mostra diferente. Segundo matéria de $O$ Estado de São Paulo, de 29 de Março de 2007, a Sabesp registra perdas de 34\% da água tratada produzida pela companhia, sendo que metade se deve pela má conservação das redes de distribuição, o que gera muitos vazamentos ao longo da rede hidráulica.

Muitas vezes, por se tratar de edificações antigas, sem manutenção, a correção dos vazamentos da rede já colabora para uma redução significativa no consumo de água desse local. A varredura e a correção se darão tanto nas redes externas como nas redes internas da edificação.

Em tal fase se utilizam alguns interessantes aparelhos como a haste de escuta, o geofone eletrônico e correlacionador de ruídos, pois, a detecção de vazamento ocorre através da localização do "fio de água", que percorre através do solo, da parede, enfim dos meios que não sejam os previstos, canos e afins, ao se escutar seu movimento.

\footnotetext{
A experiência mostra que boa parte dos vazamentos é perceptível numa vistoria atenta, preferencialmente em horário com menos ruídos sonoros, observando grama molhada, depressão no solo, piso manchado ou estufado e barulhos de água em poços de visita ou caixas de inspeção de sistemas diversos ( SILVA, 2008, p.45 ).
}

A análise dessas redes hidráulicas é fundamental devido ao grande volume de perdas que ocorre entre o alimentador predial e a primeira derivação, geralmente enterrada, com alta pressão o que dificulta a localização dos vazamentos. Tal procedimento, importante pela sua influência nos resultados do PURA, se caracteriza por gestão de redes hidráulicas. 
A Gestão de Redes Hidráulicas se apresenta como a implementação de ações que visem à garantia do desempenho requerido dessas redes ao longo do tempo para o suprimento de água aos usuários, Silva (2008).

Nessa etapa estão incluídos segundo Silva (2004):

a. Atualização do cadastro de redes externas e reservatórios: consiste em levantamento, mapeamento e análise das condições da rede existente.

b. Detecção e eliminação de vazamentos nas redes externas: entende-se pela localização e reparação de vazamentos através de simples consertos, ou substituição de tubulações ou ainda a reformulação do sistema.

c. Detecção e eliminação de vazamentos em reservatórios: Consertos de torneiras de bóia e extravasores e/ou eliminação de vazamentos nas tubulações existentes.

Após a localização do(s) vazamento(s) e sua devida eliminação, deve-se registrar todo o processo, desde as características do mesmo, sua devida quantificação bem como as tecnologias, materiais e técnicas empregadas na correção, datas e afins, para que a partir de um banco de dados se possibilite o combate às causas.

A Etapa 3, redução de consumo nos pontos de utilização, se baseia em ações locais, isto é, intervenções pontuais nos locais de consumo, banheiros e cozinhas, principalmente.

Nesse momento serão utilizados novos equipamentos, chamados de economizadores, as torneiras de acionamento automático, que, segundo alguns fabricantes reduzem o consumo em $55 \%$ e acionadores para mictório, que atinge a cerca de $80 \%$ de economia. Há também a troca das bacias sanitárias pelas mais atuais com LpF (Litros por fluxo) baixo, isto é, que tem a cada fluxo de uso o gasto de 6 litros, juntamente com o uso de válvulas que também colaboram para a restrição do consumo. 
Por fim há equipamentos ditos de base como os restritores de vazão, que são utilizados diretamente na tubulação a fim de controlar o volume de água que mesmo com a danificação aparelhos aparentes, torneiras, bacias, etc., ainda há o controle do desperdício.

Outro elemento que colabora em reduzir o consumo se trata do arejador, colocado no final da torneira a fim de diminuir a vazão com economia segundo os fabricantes de $33 \%$ do habitual.

Nessa etapa também se utiliza, conforme o perfil do publico usuário e local, a adoção de equipamentos antivandalismos a fim de evitar roubos, extravios, ou danos aos mesmos de maneira que os levem ao desperdício por mau funcionamento.

A Etapa 4, Caracterização dos hábitos e racionalização das atividades que consomem água, tem como objetivo levantar os hábitos dos usuários e o fornecimento de procedimentos mais eficientes. A fim de evitar equívocos a Sabesp salienta a necessidade de se conhecer os hábitos dos usuários, de se entender os sistemas e de se definir, baseado nas tecnologias existentes acessíveis, a mais adequada aos dois primeiros pontos.

A Etapa 5, Divulgação, campanhas de conscientização e treinamentos, tem como objetivo esclarecer e educar os usuários em geral sobre o programa, seus objetivos e o uso dos novos equipamentos a fim de conscientizar a todos sobre as problemáticas relacionadas da água.

$\mathrm{Na}$ implantação do programa, perceberam-se questões educacionais que interferiam diretamente no sucesso do programa. Desde o despreparo ao utilizar os novos 
equipamentos economizadores de água até mesmo pela cultura da abundancia, ainda existente em nossa sociedade.

A vida toda a pessoa aprendeu que a água era ilimitada. Até há o mito de que a água surge na torneira. Não precisa de mais nada, abriu a torneira está ali, surge ali. Depois não entende como ela acaba.

Existe essa coisa e é muito relativo, de alguém chegar e falar que tem pouca água ali. $\mathrm{Na}$ verdade há o uso racional da água. $\mathrm{A}$ finalidade nossa está sendo alcançada. (informação verbal) ${ }^{12}$.

Muitos usuários, crianças ou adultos, têm origem humilde, às vezes de áreas rurais, e nunca teve contato com instalações sanitárias adequadas o que, de certo modo, acabou dificultando o programa.

Por exemplo, pessoas do Norte e Nordeste têm o hábito na região de fazer a céu aberto. Você tem uma "casinha", um buraco. Eles vieram com essa mentalidade. Quando chega aqui e tem uma torneira, uma privada que têm um acionamento, estou falando das caixas acopladas, das primeiras que surgiram para a gente aqui [...]. A acoplada é que vem com a própria caixa ligada ao vaso, então, muitas vezes a pessoa não dava a descarga, ficava ali mesmo [...] (informação verbal) ${ }^{13}$.

Assim sendo, o papel educacional se mostrou fundamental para o êxito do PURA tanto na conscientização dos usuários quanto na sua importância bem como no manuseio dos equipamentos sanitários.

No primeiro momento, o trabalho educacional era desenvolvido pela própria Sabesp, porém percebeu-se a necessidade de pedagogia apropriada para um melhor resultado, assim se iniciou projetos com grupos especializados em educação, terceirizados, para o desenvolvimento das campanhas educativas.

O PURA se mostrou eficaz na redução do consumo de água nos locais onde foram implantados, porém a necessidade de se estabelecer como de caráter permanente

\footnotetext{
${ }^{12}$ Informação obtida por entrevista, Apêndice A, com Agnaldo Ruivo em 2010

${ }^{13}$ Informação obtida por entrevista, Apêndice A, com Agnaldo Ruivo em 2010
} 
as etapas 4 e 5 a fim de se manter, ou até mesmo, ampliar a redução de consumo se mostrou fundamental. Não bastava uma nova tecnologia, ou o conserto de alguns vazamentos, uma vez que o fator humano ainda se mostrava despreparado tanto para a modernidade de uma simples torneira automática quanto para a problemática da água como fator de sobrevivência. A resistência por parte de funcionários de instituições públicas como escolas, por exemplo, onde o programa foi aplicado em 2008 e 2009, se mostrou intenso em áreas como cozinha e manutenção, uma vez que o uso da água é constante e de grande valia para a execução dos serviços, a mudança de hábito se mostrou, muitas vezes, impossível, desde o simples encher uma panela até a lavagem dos pratos ou do recinto. Foram trabalhadas mais de 500 escolas, nas quais se atingiram entre 40 e $60 \%$ de economia, considerando os vazamentos da rede externa e as ações nos pontos internos. Tais reduções no consumo bem como o controle das perdas levaram a economias suficientes para se abastecer cidades como Campinas e Sorocaba.

\begin{tabular}{|l|c|}
\hline \multicolumn{1}{|c|}{ LOCAIS DE INTERVENÇÃo DO PURA } & ECONOMIA OBTIDA \\
\hline Complexo Hospital das Clínicas de São Paulo & $25 \%$ \\
\hline Edifício de Administração Sabesp - ABV & $72 \%$ \\
\hline 50 Escolas Estaduais da RSMP & $40 \%$ \\
\hline Edifício Sede Sabesp & $62 \%$ \\
\hline Escola Estadual Toufic Jouliam & $78 \%$ \\
\hline Instituto de Pesquisas Tecnológicas - IPT & $53 \%$ \\
\hline Secretaria do Meio Ambiente - SMA / CETESB & $47 \%$ \\
\hline Universidade de São Paulo / USP - Fase I e II & $26 \%$ \\
\hline Universidade de São Paulo / USP - Fase III & $37 \%$ \\
\hline
\end{tabular}

Quadro 2 - Locais de Intervenção do PURA - Fonte: Sabesp 
$\mathrm{Na}$ USP, por sua vez, quando o programa foi implantado entre 1998 e 2003, o resultado atingiu, conforme Silva (2004) cerca de $48 \%$ de economia no final do programa, de $137,881 \mathrm{~m}^{3} / \mathrm{mês}$ para $88.366 \mathrm{~m}^{3} / \mathrm{mês}$ (1998-2003), sendo que algumas unidades do campus como os laboratórios (70\%) e o Hospital Universitário (20-24\%) obtiveram maiores e menores reduções. O consumo diário per capita também obteve significativa redução de $38 \%$, de 114 para $70 \mathrm{l} / \mathrm{dia} /$ pessoa. E, considerando os gastos com a implantação $R \$ 6,37$ milhões (2003), a Universidade obteve uma economia líquida de $R \$ 46,61$ milhões (2003), valor esse equivalente, segundo Ruivo, à implantação do campus Leste.

O programa, portanto, nos mostra como a tecnologia e o constante monitoramento podem ser responsáveis por grandes reduções no consumo de água sem grandes investimentos. A questão fundamental ainda gira em torno da cultura dos usuários, não somente em relação ao uso dos novos equipamentos, mas nas pequenas mudanças nas tarefas diárias. O tempo para lavar a mão, o uso de mangueira para limpar o quintal, por exemplo, e o banho, por fim, são atividades que apesar de simples sempre carregam dentro de si peculiaridades específicas pelos seus agentes, difíceis de modificar, mas que são os principais motivos pelo grande desperdício de água.

A implantação de medidas para o uso racional da água se mostra ineficaz se não houver um estudo detalhado do diagnóstico levantado na primeira fase, bem como um monitoramento permanente das redes hidráulicas, dos pontos internos e do comportamento do usuário, este último, aliado a uma intensa campanha de conscientização. 


\section{CONCLUSÃO}

A Sabesp tem mostrado através de seus programas estruturantes, isto é, o Programa Tietê, o Projeto Córrego Limpo, o Programa Vida Nova e o PURA, uma visão sistemática e ampla do problema de saneamento da Região Metropolitana de São Paulo.

Os programas se colocam de forma complementar, atuando em pontos distintos, mas com foco no mesmo problema, a recuperação e o controle dos recursos hídricos da região. Por exemplo, enquanto o Projeto Tietê atua diretamente no rio paulista, na sua jusante, o Córrego Limpo atua nos seus afluentes, na montante, que de maneira direta e indireta acaba por levar seus dejetos ao grande rio. O mesmo acontece no Programa Vida Nova, cujo objetivo principal se concentra em recuperar e proteger os Mananciais, principais fontes de recursos hídricos da Megalópole, ao mesmo tempo em que atua na outra ponta do processo, a gestão do consumo, através do PURA.

Porém, mesmo com uma visão ampla e sistemática da problemática, com diversas parcerias com prefeituras e com outras secretarias, os pontos abordados pelos programas da Sabesp ainda assim necessitam de ações multidisciplinares, dentro de um amplo planejamento estratégico envolvendo diversas esferas do governo bem como da sociedade de um modo geral, como já acontece, por exemplo, no Programa Vida Nova, com parceria com a Secretaria de Habitação (SEHAB), e o Projeto Córrego Limpo, ambos com parceria com a Prefeitura de São Paulo, através das subprefeituras e secretarias. Mesmo assim, ainda há necessidade de um maior envolvimento da classe política e da sociedade civil, na busca de uma gestão mais colaborativa ou a participação de outras secretarias como a educação. Não há como pensar em saneamento, recursos hídricos, esgotos e poluição sem pensar na questão do crescimento urbano, no seu ordenamento, nas suas regras, inclusive na maneira como a população local interage com essa urbs, fator fundamental para o sucesso de qualquer programa. Nesse ponto, o planejamento urbano da cidade deve ser pensado e implantado, secretarias como a de Planejamento - SEMPLA devem assumir o papel de gestor utilizando ferramentas como o Plano Diretor, a Lei Orgânica do município, o Código de Uso e Ocupação do Solo e deixar de ser resultado de intervenções pontuais. 
Como exemplo desse descompasso, vê-se no Projeto Córrego Limpo, ou no Tietê, questões como macro-drenagem, contenção de enchentes, ou desconsideração de projetos viários ainda de forma latente.

Entender e trabalhar a sustentabilidade numa cidade do porte de São Paulo, com 20 milhões de habitantes, portanto, se mostra complexo, indo além da questão do saneamento público. Nesse sentido, observam-se as transformações obtidas pela Sabesp na sua trajetória, caminhando cada vez mais para uma empresa não apenas de saneamento e sim para uma de soluções ambientais, demandas do século XXI, envolvendo inclusive a problemática do lixo, por exemplo. Enfim, entramos no século XXI cientes da necessidade de se pensar a sustentabilidade urbana não da forma cartesiana de antes, mas através de uma visão sistêmica do futuro. Como Barreto nos diz:

Então do ponto de vista de sustentabilidade urbana, no que diz respeito à água, ao esgoto, estamos bem encaminhados. Nós temos outras questões, de resíduos sólidos, lixo urbano. Há outras medidas para contribuir com a sustentabilidade urbana. [...]

São ações que irão demandar problemas de uso racional e esses programas aqui, eles têm ações imediatas e têm bons resultados. Mas o grande resultado que é a melhoria da qualidade ambiental, vem a mais em longo prazo. (informação verbal) ${ }^{14}$

\footnotetext{
${ }^{14}$ Informação obtida por entrevista, Apêndice X, com Prof. Douglas Barreto (IPT)
} 


\section{REFERÊNCIAS}

ACIESP (Ed.) Glossário de Ecologia. 2 ed. [S.I.]: n.103, 1997. 352p.

BENÉVOLO, L., História da cidade. São Paulo: Editora Perspectiva, 2003. 728p.

BRUNO, E. S., História e tradições de São Paulo. São Paulo: Editora Hucitec, 1991. 1541p.

BUENO, L. M. M., O saneamento na urbanização de São Paulo. 1994. $200 f$. Dissertação (Mestrado em Arquitetura e Urbanismo). Faculdade de Arquitetura e Urbanismo, Universidade de São Paulo, São Paulo, 1994.

CAMPOS, C. M., Os rumos da cidade - Urbanismo e Modernização de São Paulo. São Paulo: Editora SENAC, 2002. 660p.

CARRELA, C. E., O Estado de S. Paulo, São Paulo, jun. 2009. Entrevista concedida a SATO, P.

CULLEN, G., Paisagens urbanas. São Paulo: Edições 70, 2006. 208p.

FERREIRA, A. B. H., Novo Aurélio Século XXI: o dicionário da língua portuguesa. 3 ed. Rio de Janeiro: Nova Fronteira, 1999. 2128p.

FREITAS, A. A., Tradições e reminiscências paulistanas. São Paulo: Edusp Itatiaia, 1985. 228p.

MOTOYAMA, S. et. al. Prelúdio para uma História: Ciência e Tecnologia no Brasil. São Paulo: Editora EDUSP, 2004. 518p.

NÓBREGA, H. M., História do Rio Tietê. 2 ed. São Paulo: Editora Itatiaia, 1978. 245p.

OSEKI, J. H., Pensar e viver a construção da cidade: canteiros e desenhos de pavimentação, drenagem de águas pluviais e de rede de esgotos em São Paulo. 1991. 226f. Tese (Doutorado) - Faculdade de Arquitetura e Urbanismo, Universidade de São Paulo, São Paulo, 1991.

PINTO, A. M., A cidade de São Paulo em 1900. São Paulo: Governo do Estado de São Paulo,1979. 336p.

PORTA, P., História da cidade de São Paulo, A cidade no império 1823-1889. São Paulo: Editora Paz e Terra, 2004. 627p. v.2.

RIBEIRO, M. A. R., História sem fim... inventário da Saúde Pública. São Paulo: Editora UNESP, 1983. 272p. 
SAMPAIO, T., São Paulo no século. XX e outros ciclos históricos. São Paulo: Editora Vozes, 1978.

SANT'ANNA, D. B., Cidade das Águas - Usos de rios, córregos e bicas em São Paulo (1822-1901). São Paulo: Editora SENAC, 2007. 320p.

SANT'ANNA, N., Metrópole: histórias da Cidade de São Paulo, também chamada São Paulo de Piratininga e São Paulo do Campo em tempos de el-Rei, o Cardeal Dom Henrique, da dinastia de Avis. (Col.) São Paulo: Departamento de Cultura, v. 2, 1950. 197p.

SAVELLI, M., Histórico do Aproveitamento das Águas da Região Paulistana. DAE, São Paulo, v.53, n.25, p.82-87, jun.1964. Palestra ministrada no Instituto de Engenharia, ano 25

SILVA, G. S. Programas permanentes de uso racional da água em campi universitários: O programa de uso racional da água da Universidade de São Paulo. 2004. 328f. Dissertação ( Mestrado em Engenharia de Construção Civil) - Escola Politécnica da Universidade de São Paulo, São Paulo, 2004.

SILVA, G. S. et al. Eliminação de vazamentos em redes externas no contexto de programas de uso racional de água - Estudo de caso: Universidade de São Paulo. Ambiente Construído, Porto Alegre, v. 8, n. 2, p.41-52, abr. / jun. 2008.

SOLIA, M.; FARIA, O. M.; ARAÚJO, R., Mananciais, Região Metropolitana de São Paulo. São Paulo: Governo do Estado de São Paulo, 2007. 143p.

TOLEDO, B. L., São Paulo, três cidades e um século. 2 ed. São Paulo: Livraria Duas Cidades Ltda., 1983. 180p.

TOLEDO, B. L., Prestes Maia e as origens do urbanismo moderno em São Paulo. São Paulo: Empresa das Artes, 1996. 304p.

VARGAS, M., Obras de saneamento (abastecimento de água, esgotos e recuperação de terras) In: MOTOYAMA, S. (Org.) Tecnologia e industrialização no Brasil - uma perspectiva histórica. (Col.) São Paulo: Editora UNESP, 1994. Cap. 4, pág. 108. 451p.

\section{Periódicos}

DAE. São Paulo: Sabesp, Secretaria de Obras e Meio Ambiente, Sabesp. 
APÊNDICE A - Entrevista de Agnaldo Ruivo, funcionário da Sabesp , Coordenador PURA por Marcelo Teixeira. (08/04/2010)

PERGUNTA - Agnaldo, eu iria perguntar a você dos pontos fortes. Você estava falando...

O SR. AGNALDO RUIVO (Sabesp) - Então. Os pontos fortes da Sabesp estão baseados em três pilares que são: Tecnologia, que busca novos equipamentos, visando sempre o nosso foco que é a economia de água; Normativa, que é tudo que é inventado, criado, seguem regras, além de mercado, também...

PERGUNTA - O Sr. escreveu Normas depois do PURA? O PURA gerou alguma necessidade?

O SR. AGNALDO RUIVO (Sabesp) - Então, esse é o ponto forte. É que estou dando uma passada... en passant.

PERGUNTA - Claro.

O SR. AGNALDO RUIVO (Sabesp) - E a parte Educacional que é a conscientização. Agora, detalhando bem esses pontos fortes de cada um dos pilares, a Tecnológica, um ponto forte do PURA é que ela está com essa necessidade, de economia hídrica, que seria fazer com que as empresas nacionais, principalmente as de São Paulo, criassem novos equipamentos.

Então, criando novos equipamentos que acionassem e até o fechamento da água, criaramse novos hábitos: as pessoas passaram a ter mais preocupação em relação ao consumo, porque a própria torneira ensinava que se tem um prazo para seu fechamento e uso daquela água.

Na parte Tecnológica, as torneiras de acionamento automático, que são aquelas que se encontra em shoppings, que acionam por sensor de movimento, foi uma necessidade que 0 próprio PURA, a Sabesp, levasse até o fornecedor, ao fabricante. Ele, por sua vez, com a parte do Projeto, com nosso Gerente de Projetos de Produtos, desenvolvesse esses equipamentos. 
PERGUNTA - A torneira de acionamento automático surgiu...

O SR. AGNALDO RUIVO (Sabesp) - Surgiu com o PURA.

PERGUNTA - Com o PURA...

O SR. AGNALDO RUIVO (Sabesp) - Com o PURA... Com a demanda que o PURA sinalizou.

Então, dizemos que isso, num período, nós reunimos todos os fabricantes e avisamos a eles que havia uma necessidade. Entramos em contato com os fabricantes, de São Paulo e Rio de Janeiro, os grandes, não é? E numa reunião solicitamos que precisávamos ter novos equipamentos, que tínhamos um projeto de economia...

PERGUNTA - A Válvula de Consumo Reduzido também?

O SR. AGNALDO RUIVO (Sabesp) - Também... Todos os equipamentos que são e que hoje, que são consagrados como econômicos, que trazem economia, chamados economizadores, são frutos de um esforço dos fabricantes e da demanda do PURA.

Bom, essa é a parte tecnológica. A parte normativa, é que, para se ter um produto que seja comercializado, ele deve passar pelas normas técnicas da ABNT, porque é um mercado que se abriu aí. Então, o ponto forte do PURA é que ele conseguiu, até mesmo não com a intenção propícia, própria, de criar um mercado. Um mercado de equipamentos economizadores, que visam economia, conforto, sem perder a praticidade de uso.

Nós do PURA, conseguimos criar um nicho de mercado, que é um ponto forte também para o mercado fabricante de metais e louças sanitárias.

PERGUNTA - Então muitas normas que surgiram em função...

O SR. AGNALDO RUIVO (Sabesp) - Surgiram em função do PURA, tanto é que a Sabesp e o PURA, ainda não sei qual nome viria à frente, participaram dessas normas técnicas, eu, 
o Ricardo, o gestor da área, participávamos, a pedido do próprio Diretor da empresa, como consumidor.

Tínhamos então um poder de palavra direta muito grande. O que dizíamos na reunião, eles acatavam e tinha que realizar.

PERGUNTA - Então, o tempo de acionamento da torneira automática foi decidido assim?

O SR. AGNALDO RUIVO (Sabesp) - O tempo de acionamento... Em conjunto... A parte técnica por parte dos fabricantes. O tempo de acionamento, o volume que queríamos que devesse sair, a qualidade do material, a durabilidade e a praticidade. Fomos lá como consumidores mesmo. Fomos como consumidores, mas, consumidores conscientes.

Para você ter uma ideia, as torneiras não possuíam tempo de fechamento. A pessoa iria fazer a barba ou escovar os dentes, enfim, no momento em que abria ela não possuía até paciência e nem o hábito de fechar. Já com o equipamento de fechamento automático, estipulamos com eles, pois poderíamos dizer: "Olha, é tanto, mas precisa ver se é possível esse tempo de uso da água..."

E nós chegamos, tanto é que hoje, a norma padrão da ABNT, diz que o fechamento de uma torneira desse tipo, economizadora, é de quatro a nove segundos. Então, hoje em dia vamos a escolas, em órgãos públicos e fazemos testes, chamamos de Testes Perdidos. O que for acima ou abaixo dessa norma, nós reprovamos. De que maneira reprovamos? A própria colocação que não foi bem feita, pois, um detalhe desse trabalho do PURA, não é porque a torneira é fabricada para esse fim, que ela irá, de imediato, ao uso. Para a colocação das torneiras, estou falando de torneira, ainda não entrei em vasos sanitários e outros equipamentos mais, ela tem que ter um gabarito de instalação. Não é só uma pessoa, pedreiro ou encanador, chegar e falar "Isso é fácil, tem que "rosquear" e pronto..." Não, tem que ter um ângulo correto e preciso de instalação, a torneira não pode ficar muito para baixo ou para cima, não pode ter dobras, enfim, tem que ser uma colocação com gabarito e gabarito do próprio fornecedor-fabricante. E sempre ter um consultor para nas primeiras instalações, até que peguem o jeito de instalar, usando o gabarito. Ele analisa se a torneira está muito para cima ou muito para baixo. Não estando na colocação correta, ele mesmo fala que deverá ser trocada, fazendo uma reciclagem total da pessoa, do técnico, que estará cursando. Pode até fazer o curso e é o que geralmente acontece.

Os encanadores passam por um curso de instalação, pois a torneira não funcionará a torneira ou vaso, enfim, além dos produtos a mais que surgiram, eles não funcionarão da 
forma correta, dentro desse padrão de quatro a nove segundos, no caso de não estarem bem colocados.

PERGUNTA - A questão do Arejador e Restritor de Vazão, também surgiram do PURA?

O SR. AGNALDO RUIVO (Sabesp) - Também surgiram.

O arejador, a peça que vai ao bocal da torneira, também foi uma solução de uma demanda existente.

Não adianta ter somente o fechamento automático. Em alguns lugares, principalmente em cozinha, você não tem como fazer isso. Você não pede, você não pede controle a uma merendeira para acionar aquilo, imagina a loucura dela: acabam os nove segundos e a cada dez segundos ela tem que apertar aquilo. Às vezes ela está com a mão ocupada, com as mãos lavando o tacho e são tachos grandes, ficando inviável em todo momento ficar apertando. O que ela faria normalmente é colocar uma fita ou algo para deixar acionada direto.

Até nisso, nesse problema de estar sempre acionando, pois havia o hábito de colocar o palito e ali ficar parado. Então, daria na mesma. As empresas tiveram que se reunir para fazer uma torneira que não possuía fechamento automático, mas de acionamento no fechamento automático.

É ao contrário: o normal é você apertar e ela já escorrer, fechando naquele período de nove a dez segundos.

Quando surgiu esse problema da pessoa solucionar de alguma forma, porque o brasileiro é muito criativo, podendo até ganhar o "Nobel da Criatividade"...

Então, o que fizeram? Ela só é acionada, quando ela está fechando. Se ela permanecer préacionada, não funciona. Só irá funcionar depois que o botão retorna...

PERGUNTA - Então se inverteu o pensamento.

O SR. AGNALDO RUIVO (Sabesp) - Inverteu o hábito de uso.

Se aquelas pessoas que apertavam e deixavam de alguma forma uma "pedrinha" impedindo sua volta, as torneiras são hidromáticas, pois voltam com a força da água e essa força numa 
torneira não é muita coisa. Qualquer palitinho que se colocava ali, barrava sua volta e ficava escorrendo.

Fez-se depois o inverso: ela só irá acionar quando retornar.

A pessoa aciona e por mais que ela deixe um palitinho para deixá-la acionada, não sai água, só sairá no retorno desse botão.

Foi uma situação em que encontramos o problema, detectamos e nas reuniões junto com a ABNT e eles ficaram estudando, quer dizer, eles são o ponto forte da Sabesp, do PURA, criou-se um nicho muito grande e forte de mercado para o fornecimento de metais e louças sanitárias.

PERGUNTA - Fora o aspecto tecnológico nessa área...

O SR. AGNALDO RUIVO (Sabesp) - Exatamente. Estimulou a tecnologia, fez com que o Gerente de Projeto e de Produto quebrasse um pouco mais a cabeça em relação a esse novo nicho. Não foi só o designer, a questão estética, que tem muito disso, mas também se criou a preocupação hídrica.

PERGUNTA - Então o PURA de uma necessidade em se evitar o racionamento, quer dizer, diminuir a dependência do racionamento...

O SR. AGNALDO RUIVO (Sabesp) - Isso! Certo...

PERGUNTA - Através da economia de água?

O SR. AGNALDO RUIVO (Sabesp) - E digo para você que não é uma exclusividade nossa. A Espanha, a França e os Estados Unidos, antes da gente ter essa consciência, já passaram por isso.

PERGUNTA - Já estavam desenvolvendo esses projetos... 
O SR. AGNALDO RUIVO (Sabesp) - Muito tempo antes. A Espanha, por exemplo, na década de 90, sofreu um desabastecimento muito grande, devido à escassez, ao desperdício, enfim, juntou uma série de fatores e a Espanha simplesmente secou, não havia mais água. Foi aí que tiveram que criar mecanismos, inclusive até o Governo cedia bacias sanitárias com o acionamento, o que hoje aqui no Brasil se tem, de seis litros, seis vírgula oito litros por descarga. Mas onde começou isso, foi fora do Brasil.

O PURA vem encontrando suas próprias soluções, porque se formos falar de, até educacional, vemos que o Brasil, por ser uma região muito grande, em São Paulo se tem um aglomerado de pessoas que vem de outras regiões, encontraremos uma mistura de povos regionais aqui. São pessoas com seus próprios hábitos.

Para se ter toda uma educação das pessoas que irão se utilizar desses equipamentos, fezse uma pesquisa muito grande para saber se não estaríamos invadindo eticamente ou moralmente alguma pessoa.

Por exemplo, pessoas do Norte e Nordeste têm o hábito na região de fazer a céu aberto. Você tem uma "casinha", um buraco. Eles vieram com essa mentalidade. Quando chega aqui e tem uma torneira, uma privada que têm um acionamento, estou falando das caixas acopladas, das primeiras que surgiram para a gente aqui... A acoplada é que vem com a própria caixa ligada ao vaso, então, muitas vezes a pessoa não dava a descarga, ficava ali mesmo...

PERGUNTA - Quando não havia a válvula, a pessoa dava descarga, mas quando tinha a caixa acoplada ela não dava? Era isso?

O SR. AGNALDO RUIVO (Sabesp) - Na verdade era hábito deles nem darem isso. No início, as primeiras experiências que temos, simplesmente eles fechavam a tampa. $O$ hábito era fechar a tampa.

É como se fosse lá, no sertão, e simplesmente eles fecharem um "tampão" e...

PERGUNTA - Fechar a tampa do buraco.

O SR. AGNALDO RUIVO (Sabesp) - Fechar a tampa do buraco. Exatamente. 
Parece incrível, parece que vivemos na ldade Média, mas não é, acontece mesmo.

Isso na década de 90.

Houve a necessidade de se ir até os locais para fazer palestras, mostrar como é o funcionamento. Lembro de algumas palestras que hoje parecem absurdas: dar uma palestra de como usar um vaso sanitário, de como usar uma torneira. Hoje, parece tão simples, que tem gente que fala que para usar uma torneira, se dá um tapa no botão dela, mas as pessoas não sabiam utilizar.

$\mathrm{Na}$ verdade muitas pessoas ficam com a mão embaixo da torneira, esperando alguma coisa acontecer, se batia em cima... Então, você vê o quanto o educacional era necessário, mas na primeira etapa foi fazer somente com que aprendessem a usar.

PERGUNTA - Uma das primeiras dificuldades, em sua opinião, foi a questão cultural?

O SR. AGNALDO RUIVO (Sabesp) - Ainda é.

PERGUNTA - Ainda é?

O SR. AGNALDO RUIVO (Sabesp) - Ainda é. Por exemplo, se você pegar, e desde aquele tempo falamos que não se varre o quintal com mangueira, se encontra muitas pessoas hoje em dia, só não varrem o quintal, quanto ficam conversando e desperdiçando, como se fosse um...

PERGUNTA - Passatempo?

O SR. AGNALDO RUIVO (Sabesp) - Passatempo. Vemos pessoas que colocam placas de "não jogue lixo nas ruas" e outras continuam jogando lixo nas ruas.

A parte educacional, para uma geração, é difícil.

O que começamos a ver que seria melhor? Não era mudar os hábitos das pessoas que já vieram com seus próprios hábitos, mas mudar a nova geração. Começamos aí a dar mais ênfase às crianças, a fazer com que elas adquirissem os hábitos... 
PERGUNTA - Na escola.

O SR. AGNALDO RUIVO (Sabesp) - Na escola.

Aí fica muito forte nossa parte educacional, em escolas. Reuniam-se as crianças e tentava fazer com que elas entendessem o funcionamento, o dar descarga, como usar...

PERGUNTA - Depois da instalação dos equipamentos de redução de consumo e água nas escolas vocês retornam com palestras explicativas?

O SR. AGNALDO RUIVO (Sabesp) - Exatamente. Até antes.

Agora vimos que tem de se ter uma abrangência maior e ela é... Os atores mudaram, os novos funcionários do PURA, da Sabesp, e os alunos, mudamos os atores. Entram empresas contratadas que têm condições para criar didáticas melhores e de contrapartida as pessoas que recebem essas mensagens seriam os Diretores de Escolas, os Professores e os Coordenadores Pedagógicos. Cada um deles iria compor um quadro que seria de multiplicador, no caso do Coordenador Pedagógico, multiplicando o que aprende com a gente, com sua didática, metodologia que possuem e passam melhor, os Professores que seriam os gestores, ou mesmo alguém que poderia fazer a gestão do consumo de água e os próprios Diretores que coordenariam. Criam-se três figuras: o Coordenador, o Gestor e o Multiplicador, dentro de uma escola.

Para quê? Para que eles possam dali, criar. O Coordenador, que sinto ser o principal, seria um especialista dentro da escola, que seria o Pedagogo. É ele que iria fazer com que toda a atividade dentro de sala de aula, fosse voltada em matérias interdisciplinares, que fizessem com que a metodologia tivesse correspondência com a matemática, mas o tema da aula seria o "Uso Racional da Água".

Imagino que poderia haver uma aula em que o Professor de Biologia, falaria sobre o ciclo da água. O de Matemática pediria algum gráfico, cálculo ou algo dessa aula que foi dada em Biologia. Ou vice-versa.

Enfim, uma disciplina servindo de ferramenta para a outra. E assim, fazer com que a parte educacional se multiplicasse em relação ao nosso projeto de como usar os equipamentos.

PERGUNTA - E onde você tem visto maior dificuldade? Por exemplo: na cozinha de uma escola, nos banheiros, laboratórios? 
O SR. AGNALDO RUIVO (Sabesp) - Olha, houve um ciclo. Houve um ciclo onde o problema maior, no começo, foram os banheiros. Havia muitas torneiras sendo depredadas...

PERGUNTA - E aí surgiu a necessidade de equipamentos antivandalismos?

O SR. AGNALDO RUIVO (Sabesp) - Exatamente. Reunimo-nos nas ABNT, colocamos em discussão e um tempo depois, eles lançaram no mercado as torneiras e os vasos antivandalismos. Resolveu!

PERGUNTA - O vandalismo diminuiu drasticamente?

O SR. AGNALDO RUIVO (Sabesp) - Diria a você que a parte educacional junto aos equipamentos mais duráveis, com um acionamento mais restrito, onde não se tem tanta peça a mostra, para você... Os equipamentos agora são soldados, enfim, houve uma melhora muito grande em relação à depredação.

PERGUNTA - Até o desaparecimento do "arejador", que antes eram roubados...

O SR. AGNALDO RUIVO (Sabesp) - Isso. Antes o "arejador" era solto e hoje temos a rosca infinita, que possui uma chave própria, em poder da Diretoria, até para que se possa abrir... E também, quando... O aluno muitas vezes pode pegar uma caneta e furar o "arejador". Surgiu o quê? Surgiu outra peça que vai dentro da própria tubulação que é o Restritor de vazão.

PERGUNTA - O Restritor de vazão.

O SR. AGNALDO RUIVO (Sabesp) - Ele tem também a mesma função. O "arejador" é a parte externa e o "Restritor" a parte interna. Um substitui o outro. Os dois juntos, diria a você, é um casamento muito bom, em áreas que possuem muita pressão. 
PERGUNTA - Por exemplo: na época em que trabalhava em várias escolas...

O SR. AGNALDO RUIVO (Sabesp) - Só respondendo. Posso dizer que hoje, dia 08 de abril, digo a você que é a cozinha. Nas escolas é a cozinha.

As Merendeiras não têm esse hábito, não sei se estou errado, mas elas possuem um tempo, 15 minutos se não me engano, de alimentar e de ter que limpar.

Como há uma redução grande de vazão de água, normalmente elas que se tornaram o "arejador".

PERGUNTA - Isso que eu iria comentar com você. Quando trabalhamos juntos com os funcionários dentro das escolas, uma coisa que havia era a questão de: ou a Diretoria reclamar que o banheiro dos Professores estava com pouca água e reclamavam da torneira, sendo que, na verdade, era o "Restritor" de vazão que estava regulado...

O SR. AGNALDO RUIVO (Sabesp) - Na verdade, é muito relativo quando uma pessoa fala que há pouca água. Como te falei. A vida toda a pessoa aprendeu que a água era ilimitada. Até há o mito de que a água surge na torneira. Não precisa de mais nada, abriu a torneira está ali, surge ali. Depois não entende como ela acaba.

Existe essa coisa e é muito relativo, de alguém chegar e falar que tem pouca água ali. $\mathrm{Na}$ verdade há o uso racional da água. A finalidade nossa está sendo alcançada.

Nosso mérito maior, a prova maior que está se realizando um trabalho bem feito, é quando há reclamação em relação ao consumo da água, de sua vazão.

Nossa finalidade é essa: primeiro - reduzir o consumo, reduzir o desperdício...

PERGUNTA - Você tem ideia de quanto reduziu em porcentagem?

O SR. AGNALDO RUIVO (Sabesp) - Tem, num parâmetro geral, numas 500 escolas do Estado, houve redução em torno de $40 \%$.

PERGUNTA - Em média, nas escolas? 
O SR. AGNALDO RUIVO (Sabesp) - Em média, nas escolas. Isso! Mas isso devido também a quê? Não só à aplicação nas escolas dos equipamentos, mas também em relação a consertos de vazamentos.

Grande parte do consumo que as escolas possuíam, era do fato das tubulações serem velhas e elas têm uma vida útil também. Então, o grande problema nosso...

\section{PERGUNTA - Vazamentos?}

O SR. AGNALDO RUIVO (Sabesp) - Vazamentos e não pense que são vazamentos pequenos, são vazamentos gigantescos, que seriam até problemas futuros de infiltração, podendo inclusive atingir até uma quadra inteira.

Nós fomos a várias escolas e vimos que as quadras, que normalmente têm tubulação passando por baixo, eu não sei se devido à movimentação dos alunos, enfim, mas a quadra é normalmente uma área em que normalmente se encontra vazamento. É onde se tem muitas rachaduras, então fomos a algumas escolas cujas salas de aula, principalmente laboratório e teatro, foram interditados há muito tempo, pois se tornaram área de risco. $\mathrm{A}$ terra já estava "fofa", havia infiltração, desnível do piso, rachaduras, então se tornaram áreas que ofereciam até um perigo para a própria escola.

Vamos e pesquisamos vazamentos com novas tecnologias...

PERGUNTA - A haste, o geofone e o correlacionador de ruído.

O SR. AGNALDO RUIVO (Sabesp) - Tudo. Vamos primeiro pela haste de escuta certo? Faz-se o teste e, mesmo assim, se for preciso, voltamos para instalar o "correlacionador" de ruído, enfim.

Existe outro método que estamos também utilizando, que é a "telemedição".

PERGUNTA - A "telemedição"?

O SR. AGNALDO RUIVO (Sabesp) - A "telemedição". Ela serve também, não só para saber... 
PERGUNTA - Explica para mim sobre a "telemedição"?

O SR. AGNALDO RUIVO (Sabesp) - A "telemedição" foi também um produto que em parceria com o PURA, não foi ele quem deu o "start", mas o PURA encontrou uma aplicação muito boa dessa tecnologia.

O que é a "telemedição"?

Antigamente havia a medição do consumo de água no próprio relógio, hidrômetro, numa leitura visual. A pessoa olhava o quanto estava passando, e era analógico, o quanto estava registrado de passagem de água em metros cúbicos, subtraía pela última leitura e se calculava. Não se perguntava o que era aquele consumo, só sabia o quanto havia consumido.

Com a "telemedição" os hidrômetros passam a ser eletrônicos, digitais, e com a capacidade de armazenamento de transmissão de dados, informações, a cada segundo. Essa leitura que era e é feita ainda visualmente, a leitura da Sabesp, necessariamente pelos funcionários que vão até ao local para verificarem, isso não mudou. Mas o PURA trouxe essa tecnologia de oferecer um serviço a um cliente, através de um pagamento mensal em que ele possa ficar sabendo sobre seu consumo, vazão e litros num tempo determinado. Se quiser saber de segundo a segundo, ele dará dados enviados segundo a segundo, do consumo daquele momento, ou de dez em dez minutos, enfim, estipula o quanto ele quer.

Esses dados de consumo são passados a uma central, para um computador, em um programa e ele pode a noite verificar se está havendo passagem de água.

PERGUNTA - Num horário onde não há uso...

O SR. AGNALDO RUIVO (Sabesp) - Exatamente, é a figura do controlador, do gestor, na verdade.

O gestor, numa escola, por exemplo, a função dele é essa. É ele olhar no computador que está havendo diferença de volume. Se à noite, de madrugada, ele vê que não zerou, é porque há vazamento. 
PERGUNTA - Como uma situação em casa, por exemplo: tudo está desligado e se você vai ao hidrômetro e vê que o marcador está girando, tem vazamento.

O SR. AGNALDO RUIVO (Sabesp) - Exatamente, tem vazamento.

É uma forma que encontramos, aliás, que adaptamos. Nossa função é essa, caçar desperdício e a "telemedição" veio para casar muito bem, e com isso conseguimos oferecer mais esse serviço ao cliente para que ele tranquilamente possa verificar se durante a madrugada existe vazamento. Havendo vazamento, existem outros procedimentos: o próprio equipamento avisa ao interessado por celular ou no próprio e-mail, ou sendo ele um gestor da água, ele mesmo irá olhar e verificar que há vazamento. Uma série de procedimentos até encontrar o vazamento.

A "telemedição" e a Sabesp são duas coisas diferentes, mas se casam de tal forma, que um parece ter nascido para o outro.

PERGUNTA - Você comentava que nas escolas há uma redução de $40 \%$ a $60 \%$ de consumo nas escolas.

O SR. AGNALDO RUIVO (Sabesp) - Isso, uma média...

PERGUNTA - Na rede externa, quanto é esse perda? Você tem uma ideia só da rede externa?

O SR. AGNALDO RUIVO (Sabesp) - Até começamos a querer fazer um cálculo assim do quanto de vazamento isso significava.

Posso dizer a você, não oficialmente, mas digo para você que em torno desse mesmo $60 \%$ de perda. Era isso mesmo.

PERGUNTA - Hoje se fala em torno de $34 \%$ ou $35 \%$ de perda...

O SR. AGNALDO RUIVO (Sabesp) - Olha, isso quem pode falar oficialmente é outro setor da Sabesp que é o PIR, que é o Programa de Redução de Água mesmo. 
PERGUNTA - PIR?

O SR. AGNALDO RUIVO (Sabesp) - Existem pessoas lá que trabalham as perdas mesmo. Acredito que esse 34\% é muito ainda. A Sabesp, nesses últimos dois anos, mais ou menos, entrou em parceria com... Acho que JAICA ou JICA, do Japão, visando à redução dessa perda de água.

Ainda está tolerável, 34\%, acho que a intenção é diminuir bem mais isso aí.

PERGUNTA - Para $20 \%$ ou $30 \%$, certo?

O SR. AGNALDO RUIVO (Sabesp) - Exatamente. Mas não tenho certeza...

PERGUNTA - Mas nas Escolas se encontraram muitas perdas na rede externa?

O SR. AGNALDO RUIVO (Sabesp) - Com certeza. A tubulação é muito velha. O tempo de existência de algumas escolas, principalmente as estaduais e isso faz com que...

PERGUNTA - Já houve convenio da Sabesp com o governo nas estaduais já?

O SR. AGNALDO RUIVO (Sabesp) - Nas estaduais, nas municipais.

O maior problema mesmo de fato é vazamento.

PERGUNTA - Há uma diferença significativa entre uma CEI, que é uma escola infantil, um EMEI que é educação fundamental e um CEU, por exemplo? Tem visto diferentes critérios?

O SR. AGNALDO RUIVO (Sabesp) - Basicamente estão no mesmo "pé". Nas escolas municipais, por serem mais novas, mais recentes, não há vazamento e a parte de torneiras, a parte hidráulica está bem mais conservada, estão em condições melhores. Não há muita 
diferença. Lógico, se me perguntar qual dessas escolas apresenta a maior probabilidade de problemas em relação a parte hidráulica, de vazamentos, digo que é o CEU.

PERGUNTA - O CEU?

O SR. AGNALDO RUIVO (Sabesp) - O CEU. Porque é o CEU engloba todas as escolas, ali é o...

PERGUNTA - Mesmo sendo novas?

O SR. AGNALDO RUIVO (Sabesp) - Não. Em relação a esse universo. Onde você pode encontrar, digo que é o CEU, pela própria dimensão, pelo tamanho dele. Na verdade o CEU é você pegar todas as CEI, EMEI, a EMEF e juntar numa só, então o CEU é isso. É fazer um aglomerado dessas escolas.

PERGUNTA - O PURA entrou também em hospitais e outros segmentos. Houve distinção em tecnologia?

O SR. AGNALDO RUIVO (Sabesp) - Com certeza. Essa é a parte forte do PURA, é saber que a solução encontrada para uma escola, que até agora falamos, não é a mesma que irá se aplicar a um hospital ou até mesmo onde estamos com projetos, em penitenciárias femininas. É um universo totalmente diferente.

Os usuários desses locais são diferentes. Os de uma escola são as crianças, os jovens, de um hospital, pacientes, visitantes, então, é totalmente diferente e para piorar ainda mais onde estamos em contato, é com as penitenciárias, seu público é o cativo, o público que a qualquer momento pode pegar e fazer uma rebelião, porque está saindo pouca água, enfim, é um universo totalmente diferente.

Então, soluções são diferentes para cada uma delas, tanto é que o PURA... Existe o PURA, nosso Programa de Uso Racional, mas a Sabesp há um tempo, acredito que há uns quatro anos, lançou o PURA Soluções Ambientais, que visa outro público. Nosso PURA aqui visa entidades públicas. O PURA SSA, que é o de Soluções Ambientais, visa a indústria e o 
comércio, entidades particulares, outra atividade, outras pessoas lidando lá, mantendo os princípios do PURA...

PERGUNTA - Segue aqui o mesmo conceito, as mesmas diretrizes?

O SR. AGNALDO RUIVO (Sabesp) - O conceito sim, não os mesmos procedimentos e diretrizes, porque ali, como te falei, vemos que para cada instituição, para cada local, até mesmo em entidade pública, há um público diferente com necessidades diferentes.

PERGUNTA - A torneira, por exemplo, é diferente? O equipamento é diferente?

O SR. AGNALDO RUIVO (Sabesp) - A torneira muitas vezes acaba sendo diferente, o uso... Na verdade o uso acaba sendo diferente.

Muitas vezes a parte educacional era tão mais importante, quanto à parte da tecnologia.

Você imagina uma penitenciária... Uma escola onde colocamos acionamento automático para chuveiro, onde acionava e caso ficasse um minuto ou dois, ou cinco minutos, acionada, isso numa penitenciária não pode ser feito. Você não irá colocar o acionamento para uma presa que tem quinze minutos de banho, não dá para colocar um limite, pois é um direito deles. Não dá para negociar com uma detenta, nesse caso, onde há o direito dos 15 minutos, mas tem o dever e acionar aquilo a cada cinco ou três minutos, enfim, é racionar a primeira vez e na segunda já está arrebentando tudo.

Há para cada local um tipo específico de racionamento...

PERGUNTA - E como fica a norma, nesse caso? Por exemplo, no caso da torneira que tem de quatro a nove segundos, na penitenciária já não pode seguir isso, precisa de certa folga.

O SR. AGNALDO RUIVO (Sabesp) - O que você tem que fazer? Tem que chamar novamente os fabricantes e explicar que queremos colocar esse tipo de equipamento num hospital, numa penitenciária e não pode ser de tal jeito.

Por exemplo, já entramos em contato, por esse motivo dos banhos das detentas, não se pode colocar uma válvula de acionamento. Não dá. Do jeito que está tem que mudar, 
porque o que se encontra hoje são chuveiros de acionamento em que se a presa quiser ficar olhando aquela água cair uns quinze minutos, ela fica. Ela toma banho, sai e a água continua a cair.

Tem que se encontrar uma solução para que ela tome seu banho e no mínimo a redução seja bem grande, numa válvula solenóide para poder fechar, alguma coisa assim. Um sensor, enfim.

O que nós fizemos? Chamamos alguns fabricantes de duchas e chuveiros e a maioria atende ao nosso pedido, e falamos a nossa necessidade. É uma demanda de mercado para o fabricante. O que eles fazem? Apresentam a solução. Se ela não serve pedimos de outra. Eles voltam novamente para a fábrica, discutem com os Gerentes de Projetos de Produto e num prazo posterior, voltam para apresentar um protótipo de solução.

Posso dizer a você agora, que no caso específico da penitenciária, quem pode falar melhor é o Ronaldo, que irá conversar com você, por ter praticamente dois projetos que ele toca para a solução da penitenciária, em que seria colocar... Para você ter ideia, no Brasil não há uma ducha que seja econômica, que dê para se ter esse resultado. No mercado nacional não há e...

PERGUNTA - Tem no mercado internacional?

O SR. AGNALDO RUIVO (Sabesp) - Tem no mercado internacional. Mas nosso foco é estimular a indústria nacional.

PERGUNTA - Nem que haja a importação de tecnologia?

O SR. AGNALDO RUIVO (Sabesp) - Exatamente. O que estamos fazendo? A princípio importamos uma tecnologia de fora, uma ducha sem ter o "Restritor", pois não adianta colocar um elas também irão arrebentar. Tem que ser outra solução.

Então está vindo uma ducha de fora, se não me engano dos Estados Unidos e ela atende a alguns princípios, a algumas necessidades nossas ali, mas em vista, lógico, é uma coisa boa que... Estamos buscando uma solução, importar uma solução para que o mercado nacional possa desenvolver. Não para fazer quebra de patente, não envolve nada disso, tanto que já recorremos ao nosso Jurídico e já perguntamos até para a nossa área de Licitação, se isso é possível, se a vinda de equipamento de fora não irá causar... 
Resguardamo-nos de todo problema que poderia surgir de algo que foge dos padrões do dia-a-dia nosso.

Ou um teste piloto, não haveria nenhum problema. Mas não colocamos nenhum equipamento ainda. Estamos esperando que alguma empresa nacional, que chamamos para cá, que apresente algum equipamento nacional.

PERGUNTA - E vocês estão prevendo a entrada nas penitenciárias quando?

O SR. AGNALDO RUIVO (Sabesp) - Na verdade nosso Diretor, através de sua Assessoria, já estava esperando isso pelo menos há uns 15 ou 20 dias atrás. Já estão cobrando pelo menos um piloto, pelo menos para mostrar...

PERGUNTA - Ano eleitoral, e tudo mais?

O SR. AGNALDO RUIVO (Sabesp) - Exatamente. Só que não houve condições.

Porque não adianta você encontrar parte da solução, pois só elimina parte do problema. Então não adianta, você tem que encontrar a solução e eliminar todo problema. Aí havia outros problemas, como te falei, essa ducha realmente é bem econômica. Ela tem um mecanismo interno que não precisa colocar protetor, ela consegue reduzir bem o consumo.

- Não diminui o fluxo de água. Ela vai diminuir o tempo?

O SR. AGNALDO RUIVO (Sabesp) - Diminui a vazão.

PERGUNTA - A vazão?

O SR. AGNALDO RUIVO (Sabesp) - A vazão. Mas não diminui a pressão. Ela perde em vazão e ganha em pressão.

PERGUNTA - E o tempo? 
O SR. AGNALDO RUIVO (Sabesp) - O tempo é o estipulado pela penitenciária e não pode alterar.

São quinze minutos de banho, direito dos detentos.

PERGUNTA - Quinze minutos com o chuveiro ligado?

O SR. AGNALDO RUIVO (Sabesp) - Quinze minutos com o chuveiro ligado. Só que se têm quinze minutos de chuveiro ligado, com um desperdício, com uma vazão de, sei lá, me parece que hoje está em 30 litros por minuto.

Essa ducha está reduzindo de seis a oito litros por minuto, sem perder, fizemos uns testes aqui, sem perder a sensação de banho.

Então, para elas não haveria problema. Para a penitenciárias e para a Sabesp.

PERGUNTA - Diferente da cozinha, onde a Merendeira reclamava que demorava mais tempo para encher o tacho.

O SR. AGNALDO RUIVO (Sabesp) - Exatamente.

PERGUNTA - Ela tinha um tempo ali limitado para todas as tarefas...

O SR. AGNALDO RUIVO (Sabesp) - Ela tinha um tempo, tinha as condições na hora para fazer o... E também a solução foi outra, não é? Tanto é que, para as próprias cozinhas, estão aparecendo outras soluções. Ao invés de estar colocando "arejador", é preferível colocar o redutor de vazão. Redutor de vazão não tem como fazer...

PERGUNTA - Não tem como controlar.

O SR. AGNALDO RUIVO (Sabesp) - E olhe lá se não quebrar lá. 
PERGUNTA - Também tinha muita gente que você colocava e voltava no dia seguinte e já tinha que trocar também.

O SR. AGNALDO RUIVO (Sabesp) - Exatamente. Íamos lá e quando voltávamos, porque começamos nas escolas e algumas vão junto para ver como estão as coisas, principalmente na licitação, ganha um tipo de torneira, então o fabricante, o consultor daquele fabricante vai ao local para que possa estar vendo se realmente está sendo colocado da forma correta, pois para ele é vantagem a colocação correta, significa que está bem no mercado.

Nossa licitação, uma das exigências que temos e fazemos para uma empreiteira, é que ela apresente produtos que sejam econômicos, senão, vai lá e troca uma torneira velha por uma nova. Não dá.

É que é importante para a empreiteira, com seus profissionais, instalar equipamentos, é o equipamento. A exigência também é para com o equipamento. Fazemos toda uma norma técnica de equipamentos e temos que comparar aquele equipamento.

Lógico, no mercado existem três ou quatro ou cinco fabricantes que fazem aquilo. Até mais, só que sabemos que há alguns novos fabricantes que imitam muito bem mas não resolvem. Tem outras exigências.

PERGUNTA - Depois que você fez a implantação do programa, num edifício, enfim, vocês retornam a esse edifício?

O SR. AGNALDO RUIVO (Sabesp) - Ah sim.

Passado o tempo, a empreiteira tem uma meta de entregar as escolas e nessas entregas de escolas temos uma série de fiscais que eles irão dar o termo de fechamento da entrega. Eles vão até o local e fazem uma vistoria de torneira em torneira.

Torneira, vaso, vazamento, hidrômetro, são responsáveis pela verificação e estando O.K., eles atestam que aquela escola está entregue.

Existe então essa preocupação antes, durante e depois.

PERGUNTA - Depois que foi entregue tem algum processo de acompanhamento? 
O SR. AGNALDO RUIVO (Sabesp) - Tem um acompanhamento de pelo menos um ano. De consumo, porque há uma fórmula que encontramos, fazendo um contrato bem "redondo" mesmo, em que pagamos $75 \%$... Os primeiros contatos foram assim, $75 \%$ eram pagos no contrato. A obra em si era paga ali. Os outros $25 \%$ eram pagos com as metas.

Para cada escola havia uma meta mínima. Por exemplo: numa escola, como chega a essa meta? Vemos os últimos seis meses, dependendo... É caso a caso. Mas se numa escola tiver tudo bonito, durante seis meses com leitura normal, colocamos seis meses em média. Medem-se essas seis, dá a média e essa média passa a ser uma redução de 10\%, dessa média, passa a ser nossa meta, ou seja...

PERGUNTA - A meta de vocês era $10 \%$ de resumo da média dos seis meses, atingindo de $40 \%$ a $60 \%$ nas escolas?

O SR. AGNALDO RUIVO (Sabesp) - Tem escola em que atingimos muito mais.

Mas é uma meta... Pensamos assim, não vamos também fazer uma coisa impossível para as próprias empreiteiras e colocar uma meta de $50 \%$ ou $40 \%$, não é essa a nossa finalidade. Era na verdade uma forma de manter as empreiteiras, por pelo menos seis meses a um ano, presas a essas, como se fossem garantias.

O contrato acabou, não tem garantia. O contrato não garante nada, a não ser o próprio contrato. Não existe aquela garantia de voltar para a escola.

Uma forma que encontramos para ter essa garantia de seis meses para a escola foi fazer com que os $25 \%$ do contrato fosse pago em metas. Uma escola que atingisse $10 \%$ abaixo da média, nos últimos seis meses, ou dependendo de como for... Mas o normal eram seis meses, ela ganhava a parcela correspondente aos seis meses.

Esses $25 \%$ eram divididos ainda em seis vezes e para cada meta conseguida, era pago um sexto dos $25 \%$.

Basicamente era isso, conseguimos fazer com que a escola tivesse uma garantia de seis meses e isso significa que se o primeiro mês, via-se as escolas que já haviam sido entregues, por isso te falei de até um ano, porque se entrega a primeira escola e já começa a contar aquele primeiro mês, mas isso não significa que a última escola tenha também que... Então, com o prazo do contrato, na última escola tinha que necessariamente casar, no máximo, com os seis meses aqui. Se no sexto mês ela conseguisse, aí até podia se pagar as parcelas totais, certo? Porque também atingiu o prazo, mas se ultrapassasse o prazo do 
contrato, por algum motivo de atraso, ela também passaria o mesmo prazo para receber também.

Foi uma solução...

PERGUNTA - Que amarrou tudo...

O SR. AGNALDO RUIVO (Sabesp) - Que amarrou tudo. As escolas tiveram garantia de seis meses...

PERGUNTA - Vocês fizeram na USP, em hospitais, escolas?

O SR. AGNALDO RUIVO (Sabesp) - A USP, a FUNDAP, agora os nomes...

PERGUNTA - Em geral.

O SR. AGNALDO RUIVO (Sabesp). - No geral posso dizer que são os órgãos públicos. Nossa meta são os órgãos públicos.

PERGUNTA - Onde teve o resultado que mais te impressionou?

O SR. AGNALDO RUIVO (Sabesp) - O que mais me impressionou e que foi até mais vitorioso, foi a própria USP. A notícia que surgiu depois de termos feito...

PERGUNTA - Foi o primeiro projeto?

O SR. AGNALDO RUIVO (Sabesp) - Foi o primeiro projeto. Mas a notícia que surgiu depois disso é que com o dinheiro economizado com a água, a USP conseguiu fazer a USP Leste... 
PERGUNTA - O valor economizado foi o equivalente a construção de uma USP Leste

O SR. AGNALDO RUIVO (Sabesp) - Precisaria ver se isso é realmente verídico, se de repente não é um exagero.

O que se comenta, pelo menos aqui na Sabesp, entre nós...

PERGUNTA - Que com o economizado?

O SR. AGNALDO RUIVO (Sabesp) - Com o economizado deu ou daria, não sei, mas daria para e foi parte da construção da USP Leste.

PERGUNTA - E nas escolas ainda estão em andamento?

O SR. AGNALDO RUIVO (Sabesp). - Não. As escolas praticamente estão todas feitas, estamos fechando outro contrato agora. As quinhentas já foram feitas. O resultado foi de $40 \%$ a $60 \%$, existem outras escolas, acho que por volta de setecentas e poucas escolas que estamos fechando também, estamos agora na fase de pagar metas e de fechar o cálculo mesmo. Não deve fugir muito disso...

PERGUNTA - Municipais e Estaduais?

O SR. AGNALDO RUIVO (Sabesp) - Essas são Municipais.

PERGUNTA - Municipais...

O SR. AGNALDO RUIVO (Sabesp) - Acredito até, pela experiência que tenho que as primeiras, que são as Estaduais, tiveram esse consumo.

Essas, agora, que são as Municipais, acredito que terão uma redução menor por serem escolas novas.

O vazamento não será encontrado, será encontrada a própria torneira que vaza, que precisa trocar, etc. e tal. 
Já fizemos na Polícia Militar...

PERGUNTA - Polícia Militar? No Teatro Municipal também?

O SR. AGNALDO RUIVO (Sabesp) - No Teatro Municipal fizemos também, na Câmara Municipal. Acho que na Câmara Municipal já começamos, alguma coisa assim.

São muitas coisas, muitos projetos que fazemos e se encaminha até a feitura mesmo e acabamos até nos perdendo um pouco aqui.

PERGUNTA -Quais são suas metas aqui? O que está programando para o futuro?

O SR. AGNALDO RUIVO (Sabesp) - Então, temos projetos de ampliação para as outras Polícias Militares, principalmente na parte da Polícia Militar que onde se dá a comunicação da Polícia. Copom ou alguma coisa assim. Essa já está assinada. Tem a parte da CEFASP, que é o Centro de Formação de Paraças, também da Polícia Militar...

PERGUNTA - Outras cidades?

O SR. AGNALDO RUIVO (Sabesp) - Outras cidades. Em Registro, que vieram também para cá para que se pudesse também colocar o PURA lá.

PERGUNTA - Em Registro?

O SR. AGNALDO RUIVO (Sabesp) - Em Registro. Hospitais, nós temos só uma negociação, fechar a negociação entre a Sabesp e a Secretaria de Saúde, para começar também, pois temos todos os diagnósticos dos hospitais, a parte de cemitérios. Em alguns cemitérios fizemos uma nova rede...

PERGUNTA - Mas aí é principalmente vazamento externo. 
O SR. AGNALDO RUIVO (Sabesp) - Isso, vazamento externo porque a gente vai ampliando nosso leque. O que a gente não tinha como foco direto, que é a rede, por exemplo. Rede não tem uso direto, mas tem vazamento, então também houve a necessidade de entrar em contato com a parte da Sabesp que lida com a rede...

PERGUNTA - Com a gestão da rede?

O SR. AGNALDO RUIVO (Sabesp) - Com a gestão da rede, fazendo também uma parceria nossa para que pudéssemos trocar as redes de alguns cemitérios também.

PERGUNTA - No caso da USP, uma área muito grande, a rede hidráulica externa sofrerá grande interferência.

O SR. AGNALDO RUIVO (Sabesp). - Por exemplo: não fizemos ainda nada em relação às penitenciárias feminina de Santana. Internamente não. Estamos com projeto, estamos na fase de orçamento. Eles tinham um problema muito grande lá que é em relação a abastecimento interno, porque a área ali recebe duas entradas de água de abastecimento.

O que acontece ali é que vinha com muita força a água daquela região do Carandiru e as válvulas que têm lá não suportavam... Tem lá um reservatório muito grande...

PERGUNTA - E antigo, não é?

O SR. AGNALDO RUIVO (Sabesp) - O pior é que é novo.

PERGUNTA - É novo?

O SR. AGNALDO RUIVO (Sabesp) - É novo, só que foi muito. Fizeram uma intervenção que parece uma piscina olímpica o reservatório deles lá. Só que não havia válvula que segurasse, porque para você manter aquele negócio sempre cheio, tem que haver uma pressão muito grande. Então a Sabesp, em cada ponto, tem suas válvulas redutoras de pressão e ali foi uma região que não daria para não colocar isso, senão, não abasteceria ali, 
o reservatório. E nisso fazer o quê? O que criou? Criou aquele reservatório deles começou a ter uma carga muito grande, uma pressão muito grande de água e nenhuma bóia segurava ali, até que eles, da própria engenharia, tiveram que fabricar uma bóia por eles mesmos. Se não me engano, até usaram pneu, alguma coisa assim, mas também não agüentou.

A pressão era muito grande e o volume também, sendo que a estrutura não agüentou. Acho que o reservatório não tem mais que quatro ou cinco anos e estava até com perigo daquele negócio se romper, rachar e seria uma tragédia, porque é muita água que tem ali e seria algo não muito bonito de se ver.

O que fizemos para solucionar esse problema? O Ronaldo, que pode falar melhor a você, pediu para que a Regional da Norte, que fizesse outra rede de tubulação ali, em tempo recorde de dois ou três meses, mataram uma rede e fizeram outra com um pouco mais de dimensionamento para que quando a água chegasse ali, chegue com menos pressão.

Para você ter uma ideia, nós, do PURA, se ficarmos só restrito àquelas velhas soluções, que havia no começo, não irá acompanhar as novas necessidades.

Como falo a você, para cada local, encontraremos uma realidade diferente, em que terá que se encontrar soluções próprias para o local.

PERGUNTA - A previsão para entrada na prisão masculina?

O SR. AGNALDO RUIVO (Sabesp) - A feminina!

PERGUNTA - Não, a feminina agora e a masculina será que virá depois?

O SR. AGNALDO RUIVO (Sabesp) - Ou seja...

PERGUNTA - Aí surgirão novas...

O SR. AGNALDO RUIVO (Sabesp) - Novas. Exatamente. Porque aí, por exemplo, parece que tudo é a mesma coisa, mas não é. A mulher sempre será mais dócil do que o homem. Com a mulher se tem menos vandalismo. Ela cuida mais de suas coisas, do que o homem. 
Temos algumas literaturas que, se colocar as mesmas soluções que encontrar ali, na feminina... Se for colocar numa delegacia ou no masculino, não dará certo. Tem que haver outra solução aí.

Para cada lugar tem que haver uma solução diferente.

PERGUNTA - E vocês estão atuando em todos os Estados ou só na região metropolitana?

O SR. AGNALDO RUIVO (Sabesp) - Nossa abrangência é a região metropolitana mesmo.

PERGUNTA - A região metropolitana?

O SR. AGNALDO RUIVO (Sabesp) - Para fora dessa região, estamos dando uma espécie de consultoria para que outras localidades estarem estruturando seu próprio PURA.

Por exemplo, ontem vieram para cá duas pessoas de Santos para saber um pouco mais em como é o funcionamento do PURA aqui.

Fomos almoçar e nas conversas informais, vimos que eles estão com intenção de fazer um PURA em Santos, oferecendo todo tipo de serviço que a gente oferece aqui. Já estamos em trato, de falar algumas coisas como quem é o público...

PERGUNTA - Aí cria a regional da Sabesp lá?

O SR. AGNALDO RUIVO (Sabesp) - De lá, do litoral.

PERGUNTA - Em cada regional começa a gerar seu próprio PURA, com cada setor e departamento dentro da central.

O SR. AGNALDO RUIVO (Sabesp) - Exatamente.

Em cada local, litoral ou interior, têm uma célula do PURA e estamos com essa incumbência de prestar consultoria a eles.

PERGUNTA - Afinal, depois de quinze anos, não é? 
O SR. AGNALDO RUIVO (Sabesp) - Inclusive ontem eu e Ronaldo recebemos uma "proposta", informal também, de estarmos indo para lá. Eles perguntam se não queremos ir para lá, pois estão precisando e dizem que seremos muito úteis. Mas é muito...

PERGUNTA - Gratificante?

O SR. AGNALDO RUIVO (Sabesp) - Gratificante.

PERGUNTA - Muito obrigado Agnaldo.

O SR. AGNALDO RUIVO (Sabesp) - Obrigado você, nós agradecemos o interesse pelos nossos programas. 
APÊNDICE B - Entrevista de Carlos Carrela, funcionário da Sabesp Superintendente da TG, por Marcelo Teixeira. (12/05/2010)

PERGUNTA -Fale um pouco sobre o Projeto Tietê? No que ele consiste para a Sabesp? Como se encontra?

O SR. CARLOS EDUARDO CARRELA (SABESP)- O Projeto Tietê iniciou com um grande movimento da população, interligado com a própria Rádio Eldorado, onde mais de um milhão de assinaturas, reivindicavam uma melhoria, na poluição do Rio Tietê. A Sabesp já vinha trabalhando num planejamento e na definição do seu Plano Diretor de Esgoto, onde com isso nasceu o projeto de Despoluição do Rio Tietê. A princípio a Sabesp conseguiu um grande financiamento com o Banco Interamericano, BID, onde se desenhou toda a primeira etapa do Projeto Tietê. Conseguimos um programa de financiamento junto ao BID de financiamento de US $\$ 900$ milhões, com 50\% de contra partida da SABESP.

O projeto vem sendo desenvolvido em etapas. A primeira teve o foco maior na construção das Estações de Tratamento, em seguida desenvolvemos a segunda etapa, conseguindo outro financiamento com o próprio BID, que terminou agora em 2009. Ainda no decorrer da segunda Etapa, planejamos toda a terceira etapa que já se iniciou.

Qual é a função básica do Projeto Tietê? . Na verdade a maior carga poluidora existente no Rio Tietê, sem dúvida é a carga orgânica, o esgoto que chega ao rio, mas não é só essa carga que polui, podemos enxergar a qualquer momento depois de uma chuva olhando para o rio, toda a sujeira que desce boiando, que chamamos de poluição difusa, que nada mais é que toda a sujeira jogada ao chão ou que está às ruas, tudo isso acaba chegando ao rio. Existem outros fatores que poluem o rio também. O Projeto Tietê é sem dúvida um projeto voltado para despoluir o rio porque tem o objetivo de retirar a carga de esgoto dele, mas não depende só dessa ação de impedir que o esgoto chegue ao rio se tratamento, executando Redes Coletoras de esgoto para captar todo esgoto produzido na região metropolitana de São Paulo, levado à uma estação de tratamento e, sim, depois de tratado lançado ao rio.

Quando chegarmos à universalização do saneamento, onde todo o esgoto gerado será coletado e tratado, o rio estará muito menos poluído, mas ainda teremos uma parte muito importante que é a Poluição Difusa que depende da conscientização de todos. A própria 
poluição do ar, por exemplo, que quando se deposita no solo, vem a chuva e carrega tudo para o rio.

PERGUNTA - É falso acreditar que só o projeto resolveria o problema do Tietê. Certo?

O SR. CARLOS EDUARDO CARRELA (SABESP)- Sim, A carga difusa, um assunto muito debatido com CETESB, a fim de se conseguir quantificar. Quanto é isso? Uma coisa é certa, quanto mais esgoto conseguimos tirar do rio, maior é a porcentagem da poluição difusa. Mas já se falou em $20 \%$ a $30 \%$ de poluição difusa que está no rio. É um trabalho que demanda ações culturais.

PERGUNTA - Hoje vocês conseguiram reduzir a mancha...

O SR. CARLOS EDUARDO CARRELA (SABESP)- O rio Tietê nasce, como todos sabem,nasce a poucos quilômetros da capital, em Salesópolis, a uns vinte e poucos quilômetros do mar e diferentemente da maioria dos rios, corre para o interior fazendo um caminho muito longo. Ele atravessa toda a região metropolitana, todo o Estado de São Paulo, deságua no rio Paraná e sai pelo lado da Argentina, para o mar.

Estamos muito próximos da nascente do Tietê, seu volume é muito baixo quando entra na região metropolitana, como a de São Paulo, que possui cerca de 19 milhões de habitantes e já recebe todo o impacto que essa população representa.

Fica muito difícil enxergarmos uma melhora no Rio como um resultado do projeto aqui.

Com a execução da primeira etapa, percebeu-se a jusante do rio, próximo à Cidade de Anhembi, uma melhora bastante expressiva nas águas do Tietê, antes da primeira etapa, já não existia mais peixe na região.

Depois de alguns anos de conclusão da primeira etapa, percebeu-se que voltou a ter peixe, famílias da região, voltaram a viver novamente da pesca, ou seja, o que se trabalhou aqui na bacia do Alto Tietê, na primeira etapa, dentro da região metropolitana, refletiu a jusante do Rio.

A mancha de poluição que chegava até a cidade de Anhembi, recuou, sendo recuperada as condições de anos a atrás. 
Consegue-se hoje enxergar uma melhora no rio, no sentido do interior, aqui na região metropolitana, a concentração é muito grande e é algo que ainda irá demorar muito para poder percebermos a diferença

Quanto aos investimentos realizados temos:

Na primeira etapa foram de US\$1.1 bilhão, com um programa de US\$900 milhões, sendo US\$ 450 milhões da Sabesp em contra partida e US\$ 450 milhões do BID, tivemos também um aporte de mais US\$200 milhões de outras fonte, chegando a um total de US\$1.1 bilhão.

O Plano Diretor da Sabesp definiu a localização das cinco Estações de Tratamento. Pertencentes ao Sistema Principal de Esgoto, assim o foco principal da primeira etapa foi à construção das outras três Estações de Tratamento projetadas. Até então se coletava e afastava o esgoto, realizando lançamentos provisórios, onde estaria previsto a passagem de um Coletor Tronco.

Todos esses lançamentos provisórios só puderam ser resolvidos depois da construção das Estações e dos Interceptores e Coletores, podendo captar todo o esgoto.

$\mathrm{Na}$ época foi um investimento grande e necessário para atender as exigências em não poder mais criar lançamentos provisórios nos rios.

Já na segunda etapa, a grande meta era de aumentar a coleta e o tratamento, conseguimos outro financiamento, também com o Banco Interamericano no valor de US\$500 milhões, com um planejamento em construir grandes Interceptores e Coletores, para que os esgotos pudessem chegar as nossas Estações.

O foco maior foi da segunda Etapa foi dado à Bacia do Rio Pinheiros. Ele, como grande afluente do Tietê, recebeu interceptores ao longo de suas margens para captar todo esse esgoto, levando-o para a Estação de Tratamento de Barueri e não mais para o rio.

E olhando no mapa dá para se ter uma noção do tamanho da área que foi contemplada com redes de esgotos nas margens da Represa Billings. Tivemos que construir dezenas de pequenas estações elevatórias para poder bombear todo o esgoto que drenar para dentro da Represa.

O grande desafio na execução de obras de esgoto é que dependemos das declividades nas tubulações que na maioria das vezes levam a construção a grandes profundidades. Levando também a criação de estações de bombeamentos. 
PERGUNTA - Uma das dificuldades também é o fato de que a maioria das obras são "enterradas"...

O SR. CARLOS EDUARDO CARRELA (SABESP)- São obras complexas. Imagine hoje executar obras nas Marginais dos principais rios da cidade, em avenidas movimentadas como as de São Paulo, onde para se abrir uma vala teria que interditar faixas, ficaria praticamente impossível.

Além desse fator de ocupação de faixas, temos também a dificuldade de execução de valas muito profunda para assentar as tubulações necessárias. Com isso, a metodologia de obras não destrutivas ( túneis) é muito utilizada, ou seja obras enterradas.

PERGUNTA - Aí a opinião pública não entende...

O SR. CARLOS EDUARDO CARRELA (SABESP)- É, acaba não conhecendo.

Quando fizemos a obra ao longo do Rio Pinheiros, a 16 metros de profundidade, tínhamos um Interceptor com três metros e meio de diâmetro, era um grande túnel, onde fizemos até um espaço no interior da tubulação para visitas, onde várias escolas participaram. Todos podiam conhecer e ver o Projeto Tietê, dentro do túnel onde hoje já passa esgoto. Todos que visitavam, ficavam muito surpresos e não imaginavam o tamanho da obra, sendo que na superfície não existe quase ocupação pela obra. Já estamos com quinze anos de projetos e passamos por situações especiais com relação à metodologia construtiva das obras.

PERGUNTA - Nesses últimos 15 anos é que tem tido uma continuidade?

O SR. CARLOS EDUARDO CARRELA (SABESP)- Acho que um dos pontos positivos do projeto é a continuidade das etapas, desde o início em 91, tivemos uma grande adesão da população, que de certa maneira, contribuiu para essa continuidade. Tivemos uma pequena paralisação de dois anos entre a primeira e a segunda etapas, devido a um momento financeiro do país,mas logo se conseguiu se dar continuidade.

Tal fator não aconteceu na passagem da segunda para a terceira, seu planejamento começou a ser estudado há três anos. 
Estamos próximos de assinar com o BID, a terceira etapa, ontem mesmo estávamos em Brasília, fechamos últimos acertos e deveremos assinar o financiamento no começo do segundo semestre.

Já temos desenhada a quarta etapa do Projeto Tietê e provavelmente deveremos discutir em breve seu planejamento.

PERGUNTA - Isso para 2018?

O SR. CARLOS EDUARDO CARRELA (SABESP)- 2018 é a data prevista para essa etapa aconteça. Devemos executar redes coletoras em todas as áreas liberadas.

As áreas ocupadas irregularmente, isto é, as situações irregulares, ocupações desordenadas, e dependem de ações que não dominamos. Como já comentei, o esgoto corre por gravidade e geralmente as tubulações são executadas nos fundos de vales, próximos aos córregos, onde está o ponto mais baixo, e justamente onde essas ocupações, aí dependemos do trabalho de remoção e desocupação para que consigamos passar com os coletores.

PERGUNTA - Uma região, inclusive, grande poluidora.

O SR. CARLOS EDUARDO CARRELA (SABESP)- Exatamente.

Para esses pontos, já existe um planejamento da Prefeitura em atuar com essas remoções, fator esse muito oneroso e complicado. Tal fator leva a um planejamento da Prefeitura se estender além de 2018.

Um planejamento da Sabesp, a princípio, comparando esse trabalho que fazemos com a Prefeitura, onde estaremos atuando, isso acaba se prolongará um pouco mais. Exatamente por esse ponto, que em 2018 teremos nossas obras executas apenas em pontos possíveis, que não for impedido por esse tipo de ocupação, e também nas expansões da cidade.

PERGUNTA - Vai crescendo a cidade...

O SR. CARLOS EDUARDO CARRELA (SABESP)- A universalização do Saneamento, significa ter redes coletoras de esgoto em todos os locais possíveis de assentamentos, 0 
que também não significa dizer que todo o esgoto gerado nesses locais será captado pois as ligações para serem executadas dependem dos moradores aceitarem a conexão.

Existem ligações clandestinas que acabam sendo lançadas nas galerias, e que com isso o esgoto sendo levado para rio.

A Sabesp possui um programa chamado Córrego Limpo que de certa maneira consegue determinar esses pontos clandestinos.

PERGUNTA - Ele surgiu dentro do "Projeto Tietê"?

O SR. CARLOS EDUARDO CARRELA (SABESP)- Não. O "Córrego Limpo" surgiu entre uma parceria, da Sabesp com a Prefeitura, que vem dando muito certo.

Como já mencionei, não conseguimos perceber o rio mais limpo aqui na região metropolitana mesmo com todo trabalho que é feito não se consegue enxergar. Agora, imagine um córrego menor, onde temos nossas redes todas instaladas ao longo do seu percurso, quer dizer, então não há motivo para ele esteja poluído.

Dessa forma, as equipes que atuam no Córrego Limpo, conseguem detectar os pontos de lançamentos irregulares e retira-los. Chamamos de "pente fino" da Prefeitura com a Sabesp para começar a identificar ponto a ponto. A Sabesp faz a intimação do imóvel para se conectar e a prefeitura tem o poder de multar para que isso aconteça. Com essas ações estamos tendo bom resultados, as pessoas começam a perceber a melhora do rio. Começam a cobrar, começam a denunciar, enfim, começam a curtir aquele córrego limpinho à frente de casa, imagina?

PERGUNTA - O senhor acha que surgiu do "Projeto Tietê"? O "Projeto Tietê" percebeu...

O SR. CARLOS EDUARDO CARRELA (SABESP)- Foi uma felicidade. Não saiu do projeto, saiu de ações das Unidades de Negócio... A ideia de recuperar um pouco, de questionar o porquê de o córrego estar sujo, por que ele está poluído ainda? Depois também aconteceu o envolvimento da Prefeitura, pois tem ações que temos que fazer em conjunto, senão não acontece. 
PERGUNTA - O fato de vocês não estarem com todas as cidades na região metropolitana...

O SR. CARLOS EDUARDO CARRELA (SABESP)- Isso com certeza. Tem esse fator, não falamos disso ainda, mas em municípios em que a Sabesp não opera, não temos o domínio de planejar todas as ações necessárias para que o esgoto dos municípios não chegue ao rio. Aí depende das Prefeituras.

Nos municípios que operamos, depende de um planejamento para que os esgotos, sejam tratados.

No caso de Guarulhos, existe já um planejamento de obras, mas até hoje o tratamento é quase de seus esgotos. Todo o esgoto que é gerado lá é lançado ao rio, que passa pela região.

Esse problema com os municípios é um fator também que contribui para a poluição do rio.

Existem algumas tratativas da Sabesp, com alguns municípios, em estar recebendo o esgoto e tratando-o para lançar ao rio.

Em parte estamos preparados também para receber esse volume gerado nos municípios, mas depende de acertos políticos, entre Prefeitos e a Sabesp.

O Tietê nasce aqui, em Salesópolis, corre e atravessa São Paulo todo, e ele é dividido em bacias hidrográficas. O "Projeto Tietê", na região metropolitana, é do Alto Tietê, O "Projeto Tietê" é desenvolvido só dentro da Bacia do Alto Tietê.

PERGUNTA - Quais são as maiores dificuldades que vocês encontram no projeto?

O SR. CARLOS EDUARDO CARRELA (SABESP)- São essas ocupações irregulares, esses fundos de vales ocupados, isso é algo que só se consegue tratar junto com a Prefeitura, ela também tem que ter um fôlego para dar condição para se executar as obras,e esse é um dos maiores problemas.

PERGUNTA - O projeto de mananciais também seguem essa linha?

O SR. CARLOS EDUARDO CARRELA (SABESP)- Exatamente. 
Esse projeto também tem a ver, é outro financiamento, não está dentro do "Projeto Tietê", mas contribui também.

PERGUNTA - Precisa de um programa educacional para evitar a poluição difusa?

\section{O SR. CARLOS EDUARDO CARRELA (SABESP)- Sim.}

Sempre que possível, quando temos a chance, apresentamos o projeto, levamos à comunidade para perto do rio para mostrar sua situação.

Já fizemos um trabalho na região sul, dentro de um barco que navega pelo rio Tietê, não sei se você já viu, reunimos os formadores de opinião, os líderes comunitários dentro do barco para navegar pelo rio, aproveitando para explicar e mostrar todo o programa, sobre a importância de estarem fazendo suas ligações de esgoto em nossas redes uma vez que havíamos instalado a rede na região. Ao retornarem para seus bairros, acontecia um trabalho de boca a boca e dava que deu um bom resultado.

A conscientização das pessoas de se ligarem à rede, é um processo muito importante para o projeto como um todo, existe uma expectativa de ligações e o resultado acaba ficando longe do esperado, sem ações como essa. Com isso, existem muitas ligações que não estão em nossas redes e os investimentos necessários foram realizados.

Outro ponto importante que precisamos trabalhar é também a conscientização das pessoas em relação a toda a sujeira jogada nas ruas que após uma chuva tudo acaba dentro do Rio Tietê.

Antigamente as pessoas moravam à beira de rio e todo lixo era, joga direto rio. Usava-se o rio para afastar a sujeira.

A Globo quando fez aquela série sobre os rios, repetiu varias reportagens sobre esse assunto, ela ficou batendo durante todo o mês sobre esse problema, deixou bem clara essa cultura. Tem que "cair à ficha" da população, se realmente nós queremos um rio limpo. Depende de tudo isso, e das ações que o Governo vem tomando, que não são poucas, mas que, para dar resultado, tem que haver a cobrança de todos.

PERGUNTA - E é inevitável. O Governo quando fala do Tietê, o povo já se lembra do Sena, do Tâmisa...

O SR. CARLOS EDUARDO CARRELA (SABESP)- Ah sim... Há comparações. Para se comparar, precisamos levar em conta alguns aspectos muito importantes, eles têm uma 
diferença muito grande, vem de encontro ao que já foi falado, a vazão do Tâmisa é muito maior do que a do Tietê. O Tietê varia de 35 ou 30 metros cúbicos por segundo, ao passar pela região metropolitana. O Tâmisa tem uma vazão mais que o dobro, um volume muito maior. Estamos falando de 19 milhões aqui na região metropolitana, que também se compararmos é muito maior e fica longe, além do tempo de projeto do Tâmisa já percorrido em torno de 100 anos. Estamos aí com um projeto com 15 ou anos. .

PERGUNTA - Mas tem usado algum parâmetro? Alguma tecnologia internacional?

O SR. CARLOS EDUARDO CARRELA (SABESP)- Em termos de tecnologia, foi o que já comentei. Nas obras de esgoto, estamos sempre buscando novas tecnologias até por conta da complexidade das obras como exemplo das obras subterrâneas.

PERGUNTA - Na área tecnológica, por exemplo, a Sabesp é uma das melhores...

O SR. CARLOS EDUARDO CARRELA (SABESP)- Hoje existem empresas no Brasil que têm total capacidade de estar construindo obras complexas, com a tecnologia avançada, não ficamos devendo nada para empresas de fora.

No começo do projeto, estávamos um pouco atrás de uma tecnologia adequada, principalmente em relação à sistema não destrutivo. Hoje, as empresas possuem equipamentos, estão sempre indo para fora em busca de novidades, Acho que temos mais problema com o volume de obras que ainda têm que executar e os recursos para isso.

PERGUNTA - Em relação à Sabesp, a mudança de gestão, muda muito em algum sentido?

O SR. CARLOS EDUARDO CARRELA (SABESP)- É, já foi diferente.

Essa conscientização, a cobrança pelo meio ambiente mais saudável, passou a ser bem maior, nossas estatísticas em relação à mortalidade infantil em áreas já saneadas mostram claramente grandes recuos nos índices. Quando você abastece de água potável e esgoto tratado uma região isso fica muito claro. 
Por esses motivos é que não acreditamos que uma nova gestão venha a querer interromper um projeto como o do Tietê. Não se consegue mais interromper, um programa tão necessário como esse. Sempre teremos novas regiões para expandir o saneamento na região metropolitana.

Olhando em nosso mapa, podemos perceber claramente essa expansão. Conseguimos comparar as redes existentes antes do projeto e as que estão projetadas para serem executadas, onde estamos indo cada vez mais longe para implantar nossos sistemas de esgotamento.

Além disso o crescimento populacional projetado para a Região metropolitana nos próximos 15 anos, aponta um crescimento acentuado nas regiões periféricas e um crescimento negativo na região central, justamente onde já temos nosso sistema de esgotamento consolidado. Toda essa situação impacta tremendamente nos custos dos empreendimentos.

PERGUNTA - Se considerar também que muita gente esquece que o rio é suprapartidário, e regional, não é só de São Paulo.

O SR. CARLOS EDUARDO CARRELA (SABESP)- Sim, exatamente.

PERGUNTA - Fica mais difícil ainda a negociação.

Além dessa questão de 2018, quais são as perspectivas para o futuro desse projeto? Do Tietê? Do ponto de vista da Sabesp mesmo?

O SR. CARLOS EDUARDO CARRELA (SABESP)- Nós estamos fechando o financiamento, da terceira etapa que somando todas as fontes de recursos envolvidas, chega à casa dos US\$ 1.05 bilhão, a maior parte é com o BID, um programa de U\$800 milhões, com duração prevista para 6 anos.

Para esse período, já garantimos os recursos, para que esse planejamento aconteça. Existem já as áreas definidas, onde iremos trabalhar coletar todo o esgoto gerado. A Empresa possui uma meta em chegar em 2018 com redes de coletas instaladas a fim de atingir um patamar muito próximo da universalização, teremos que sobrepor para que isso aconteça. Já existe um grupo planejando a quarta etapa para definir seu escopo até o final do ano. Temos que fazer os projetos, contratar as obras, e conquistar novos financiamentos. 
PERGUNTA - A obra de contenção de enchentes colaborou com essa percepção?

O SR. CARLOS EDUARDO CARRELA (SABESP)- . Toda a obra de canalização é uma obra que também não está dentro do projeto Tietê, acho que ela contribui sim, as margens ficaram melhores, mas em termos de despoluir o rio, as contenções podem até ajudar na execução de algumas obras onde há ligações, mas não é esse o objetivo. O objetivo é o de contenção e de rebaixamento da calha.

PERGUNTA - Não aumenta a vazão? Ou aumentou?

O SR. CARLOS EDUARDO CARRELA (SABESP)- O rebaixamento pode até ter contribuído para melhorar a velocidade e aliviar as enchentes. Foi mais trabalhando para as enchentes, nada a ver com poluição.

PERGUNTA - Só para que a gente tenha um pouco a imagem, não interferiu?

O SR. CARLOS EDUARDO CARRELA (SABESP)- Não. Muita gente pergunta isso. O que contribuiu? Está dentro do projeto, não está? É um projeto do Estado também em melhorar, as margens, mas não é voltado para a despoluição do rio, é voltado para o rio.

PERGUNTA - É que a percepção que se tem do rio Pinheiros é de que está um pouco melhor que a do Tietê, mas não necessariamente esteja menos poluído que o Tietê.

O SR. CARLOS EDUARDO CARRELA (SABESP)- O rio Pinheiros é um rio, acredito, que pode se conseguir um resultado mais rápido, aparentemente, comparando com o Tietê. Agora, na terceira etapa, iremos fechar praticamente toda a linha de interceptores ao longo das margens do Rio Pinheiros.

Com isso, poderemos captar todos os lançamentos ainda existentes no rio. É evidente que a Bacia que drena para o Pinheiros é enorme e tem muito ainda o que fazer, se você olhar para a periferia, vai perceber as ocupações irregulares que a Prefeitura tem que trabalhar com remoções para viabilizar as execuções dos coletores. 
Mas o Pinheiros é um rio que imaginamos mais próximo de ter uma melhora aparente em relação ao Tietê.

PERGUNTA - O rio Pinheiros está incluído no Projeto Tietê

O SR. CARLOS EDUARDO CARRELA (SABESP)- Sim

PERGUNTA - É Projeto Tietê?

O SR. CARLOS EDUARDO CARRELA (SABESP)- É do Programa Tietê, porque é um dos maiores afluente do Tietê. Tudo que se faz no Pinheiros, reflete no resultado do Tietê.

PERGUNTA - E a relação das suas margens que se tem é diferente. As ocupações laterais, os edifícios que têm...

O SR. CARLOS EDUARDO CARRELA (SABESP)- É diferente. Mas a bacia que corre para o Pinheiros é enorme. É muito grande.

PERGUNTA - Com bastante ocupação irregular.

O SR. CARLOS EDUARDO CARRELA (SABESP)- A bacia que drena o Pinheiros é algo grande. Com muitos problemas nas regiões periféricas.

PERGUNTA - De áreas degradadas?

O SR. CARLOS EDUARDO CARRELA (SABESP)- Ocupação desordenada. Isso é uma coisa complicada.

Mas acredito que o Pinheiros irá apresentar uma melhora antes que o Tietê, de visual. Isso vai acontecer.

Agora, ver totalmente despoluído mesmo, teremos ainda muito trabalho... 
PERGUNTA - Acho complicado na Sabesp. Como é um trabalho enterrado não dá voto? É difícil...

O SR. CARLOS EDUARDO CARRELA (SABESP)- Esse pensamento é muito antigo mas acho que isso não acontece mais.

PERGUNTA - E quando houve essa...

O SR. CARLOS EDUARDO CARRELA (SABESP)- Foi a cobrança da sociedade e a criação do Projeto Tietê, quer dizer, a coisa pegou e não tem como hoje, alguém chegar aqui, algum Governador chegar e não ter investimento para o Saneamento. Não tem como não fazer isso.

A obra enterrada não pode ser ou não motivo de voto. 
APÊNDICE C - Entrevista de Ricardo Corrêa Sampaio - PMSP coordenador do Projeto Mananciais, por Marcelo Teixeira. (09/06/2010)

PERGUNTA - Poderia me falar um pouco do que se trata o Projeto Mananciais (Vida Nova)?

RICARDO CORRÊA SAMPAIO(PMSP): O Projeto consiste na recuperação das áreas no entorno das Represas Guarapiranga e Billings. Iniciou-se em 1994, com o antigo Projeto Guarapiranga, e posteriormente foi ampliado para a Represa Billings tornando-se o projeto atual. Ele atua na reurbanização de áreas degradadas através de reassentamento de parte dos moradores, implantação de infra-estrutura (asfalto, iluminação pública, esgoto, água encanada, áreas de lazer e equipamentos públicos) e trabalhos comunitários socio-educacionais.

PERGUNTA - Trata-se, portanto, de um projeto multidisciplinar?

RICARDO CORREA SAMPAIO(PMSP): Exatamente. Ele envolve diversas secretarias da PMSP, como a Secretaria Municipal do Verde e Meio Ambiente, a própria SEHAB, a Sabesp, a CETESB, os governos Estadual e Federal, o Ministério Público, outras prefeituras, entre outros.

PERGUNTA - Quais são as maiores dificuldades do Projeto?

RICARDO CORRÊA SAMPAIO(PMSP): Uma delas, se não a maior, é a complexidade das relações entre os tantos agentes envolvidos, os citados anteriormente, como a própria sociedade. Trata-se de 2,5 milhões de habitantes na região, instalados há mais de 20 anos no local. Cada Secretaria, cada agente, possui uma preocupação especifica e aliar todos os interesses, demonstrar à comunidade os projetos e seus ganhos, e convencê-los a uma participação mais efetiva é uma tarefa bastante complexa. Outro ponto bastante delicado é o 
reassentamento das famílias. É muito difícil chegar a um morador e informá-lo: "Olha, o senhor precisa sair desse local, a prefeitura pagará um aluguel e, no final das obras, o senhor receberá um novo local para morar”. Eles, muitas vezes, não acreditam, desconfiam, não aceitam. Trata-se de 250 mil moradores a serem reassentados em todo o projeto o que torna esse processo ainda mais complicado. E, por fim, a alternância de poder também se mostra como um fator a ser considerado, pois a cada quatro anos há uma necessidade de se trabalhar com novos agentes políticos. Explicar, demonstrar os resultados, algumas vezes até convencer da importância do projeto para conseguir sua manutenção bem como a disponibilidade de recursos.

PERGUNTA - Como é o processo de reassentamento?

RICARDO CORRÊA SAMPAIO(PMSP): Como dito, serão reassentados cerca de 250 mil moradores, em alguns locais previamente escolhidos ora por necessidade ambiental, ora por questões de infra-estrutura, ou por serem áreas de riscos. Seria impossível pensar em realocar os 2,5 milhões de habitantes da região a fim de proteger os mananciais, seria necessário uma nova cidade, portanto, os moradores são realocados para outras moradias, na mesma região, cujos alugueis são pagos através de uma bolsa auxilio já prevista no orçamento total do projeto, o que dificulta ainda mais todo o processo, por se tratar de uma única verba para tudo, e a PMSP, através de todos os agentes envolvidos, reurbaniza a área com novas moradias, água, esgoto, áreas de lazer, iluminação pública, equipamentos públicos, enfim tudo necessário para uma moradia com qualidade de vida.

PERGUNTA - E como tem sido a resposta da população local?

RICARDO CORREAA SAMPAIO(PMSP): Em algumas regiões ela tem sido muito boa, quase de imediato. Com a implantação de áreas de lazer, campos de futebol, equipamentos públicos, a comunidade, carente até então dessa atenção, dá uma resposta muito positiva. $O$ fato de o espaço público ser ocupado com novos usos, o 
futebol, por exemplo, faz com que este espaço seja mais respeitado. Por outro lado, há regiões ainda dominadas pela marginalidade, nesses casos a população ainda se encontra bastante reprimida, ou em outros casos que ainda não possui uma cultura de valorização do espaço urbano e ambiental, levando a uma necessidade de um trabalho sócio-educacional intenso de conscientização na comunidade.

PERGUNTA - Tratando-se de um projeto da PMSP como se dá a relação com outras prefeituras vizinhas as Represas?

RICARDO CORRÊA SAMPAIO(PMSP): Elas entram naquela complexidade de relacionamento citada. Algumas prefeituras acordaram conosco e se conectarão a rede em instalação para o desvio de esgoto até a Estação de Tratamento de Esgoto de Barueri (ETE-Barueri), outras ainda não possuem sistema de tratamento de esgoto e o relacionamento, muitas vezes, se mostra mais complexo.

PERGUNTA - Há a implantação de rede de água e esgoto. Como é feita? Esse é o papel da Sabesp?

RICARDO CORRÊA SAMPAIO(PMSP): Toda a implantação da rede de água e esgoto é feita pela PMSP em convenio firmado com a Sabesp. A Sabesp coordena os projetos e do aval a obra implantada para sua gestão posterior.

PERGUNTA - Isso já tem mostrado efeitos positivos na despoluição dos Mananciais?

RICARDO CORRÊA SAMPAIO(PMSP): Sim. Muito. Apesar de ser um trabalho bastante demorado, de longuíssimo prazo. Acreditamos que atingiremos a meta de universalização do esgoto e da água e a partir desse momento a despoluição dos mananciais acontecerá de forma mais visível. 
PERGUNTA - No projeto como um todo, quais são os indicadores de avanço?

RICARDO CORRÊA SAMPAIO(PMSP): São muitos. Devido à complexidade do projeto, trabalhamos com indicadores de diversas áreas: saúde, meio ambiente, educação, segurança pública, etc. Enfim o projeto atua de forma global, a CETESB, por exemplo, sempre faz medições nos locais, a secretaria da saúde está acompanhando os índices de melhoria da saúde pública, pois quando se canaliza um esgoto, despolui um córrego, implanta habitações adequadas, automaticamente a saúde da população melhora consideravelmente.

PERGUNTA - A Sabesp está trabalhando com o ano de 2018 como meta de universalização da água e do esgoto. Como o senhor enxerga esse horizonte?

RICARDO CORRÊA SAMPAIO(PMSP): Trata-se de uma meta factível, claro. Todos os esforços caminham para essa conquista, porém deve se ressaltar que esse projeto deve ter caráter permanente, pois a cidade, bem como a sociedade, é dinâmica, sofre mudanças durante seu processo de crescimento e isso deve ser constantemente monitorado. O que vemos hoje se deve ao fato de não ter havido até então um monitoramento, um controle, por menor que seja possível, dessa ocupação. Não basta denominar uma área como rural e acreditar que não será ocupada, que se encontra "congelada". A população que ocupa essa região não se encontra lá por opção, e, sim, pela falta dela. É necessário ficar atento a essa ocupação e a maneira como ela progride e acompanhar esse progresso com a instalação de equipamentos adequados, transporte público, escolas, hospitais.

PERGUNTA - Mas como será controlado esse crescimento, uma vez que, com a melhoria das condições do local, haverá inclusive uma valorização da terra e, talvez, até uma especulação imobiliária?

RICARDO CORRÊA SAMPAIO(PMSP): A valorização da terra, em minha opinião, não deve ser vista como algo terrível. Ela também traz benefícios, como uma 
ocupação mais regular, mais digna. Se, por exemplo, houvesse tido um direcionamento para a ocupação dessas áreas com habitações de poder aquisitivo maior, com menor adensamento, hoje não teríamos uma ocupação desordenada, nem seus impactos agressivos aos mananciais. A questão não está na valorização da terra mas na legislação e na fiscalização.

PERGUNTA - Pode nos falar um pouco mais da legislação?

RICARDO CORRÊA SAMPAIO(PMSP): A legislação que havia na região se caracterizava por ser muito restritiva e obsoleta, não condizendo com a realidade da região. A legislação considerava a região como zona rural, e a PMSP, acreditando assim, simplesmente não levava nenhuma infra-estrutura a fim de tentar coibir a sua ocupação. Essa também foi uma fase bastante difícil, pois foi necessário uma negociação bastante intensa a fim de flexibilizar a legislação local para que se pudesse intervir de forma adequada, assentando a população, oferecendo os serviços e capacitando-a a fim de ocupar o espaço com qualidade de vida gerando renda.

PERGUNTA - Há projetos de geração de renda na região?

RICARDO CORRÊA SAMPAIO(PMSP): Sim. Após a reurbanização da região, há um intenso trabalho comunitário a fim de não apenas conscientizá-lo dos cuidados com a sustentabilidade da região mas também de capacitá-los de forma com que haja uma geração de renda para a população local a fim de explorar o espaço sem que haja sua degradação. Quem sabe ela venha a se tornar um pólo turístico para a própria RMSP.

PERGUNTA - Nesse sentido vem ao encontro dos Parques Lineares em implantação? 
RICARDO CORRÊA SAMPAIO(PMSP): Isso mesmo. A SVMB vem implantando parques lineares nas margens das represas e em outros locais a fim de estimular 0 lazer local, e ainda, se possível atrair com o tempo um turismo para essa região que é bastante rica em atrações com um potencial enorme a ser explorado.

PERGUNTA - Há a preocupação de se recuperar as margens dos mananciais?

RICARDO CORRÊA SAMPAIO(PMSP): Sim, tanto os parques lineares como as áreas de lazer junto aos novos assentamentos acabam por ter esse objetivo, recuperar e proteger as águas das represas. Caso fosse apenas delimitada uma área de proteção sem uso, essa área voltaria a ser ocupada, por isso a necessidade de se dar um uso a essas áreas margeantes, como parques e áreas de lazer.

PERGUNTA - Há algum projeto no mundo ou brasileiro, no conhecimento do senhor, utilizado como parâmetro?

RICARDO CORRÊA SAMPAIO(PMSP): Do nosso conhecimento não há nenhum projeto desse porte. Todos os números relativos a esse projeto dos Mananciais são astronômicos. Há projetos de despoluição na Europa, Coréia, mas nenhum que nós saibamos que tenha uma população desse porte, nem atue numa área tão extensa. 
APÊNDICE D - Entrevista de Douglas Barreto, coordenador do IPT, por Marcelo Teixeira. $(03 / 05 / 2010)$

PERGUNTA - Professor, nome, formação, por favor?

SR. DOUGLAS BARRETO (IPT) -Douglas Barreto, Engenheiro Civil, Mestrado em Instalações Prediais pela (ininteligível) University, na Escócia, Doutorado em Sistemas Ambientais Urbanos, pela Faculdade de Arquitetura e Urbanismo da USP.

PERGUNTA - O Senhor trabalha como Coordenador do curso de Mestrado do IPT?

SR. DOUGLAS BARRETO (IPT) - Sim, Coordenador do Curso de Mestrado em Habitação.

PERGUNTA - E isso, me parece, tem uma reação em relação à questão do PURA, aqui na USP. Como foi?

SR. DOUGLAS BARRETO (IPT) - Resgatar a história um pouco. Vamos lá.

Tendo como referência a ECO 92, vamos situar 1992 como um marco no Brasil e no mundo, do estabelecimento da Agenda 21. A partir do Rio ECO 92, várias ações, ou várias pretensões foram assumidas, por Governos de vários países e depois, pelo Governo Brasileiro, depois o Estado Brasileiro e depois no Município. Teve esse desdobramento.

Dada essa tônica, dois anos e meio depois, em 1994, a Sabesp contratou um trabalho, um projeto de pesquisa, onde participou a Escola Politécnica e o IPT, para que a gente desenvolvesse o que seriam as bases de um programa de uso racional da água. Esse programa tinha como base: a parte de legislação, a parte de avaliação laboratorial, a parte de formação do programa mesmo, de uma estruturação do programa e depois a aplicação dessa estruturação desse programa.

Então, de 1994 até 1995, 1996, por volta de dois anos, a Escola Politécnica e o IPT Instituto de Pesquisas Tecnológicas, trabalharam em conjunto nesse que foi o programa, que se chamava o projeto Programa de Uso Racional, mas na realidade foi a gênesis, o começo ou a estrutura de um Programa de Uso Racional para a Sabesp. 
Entre 1996 e 1998, nós junto com um segundo desdobramento de trabalho, o desenvolvimento de programas de uso racional de água para edifícios, ou para edifícios entendidos como um todo, seja ele comercial, seja um campus universitário, uma fábrica... Então montamos várias aplicações piloto. Fizemos em hospitais, escolas, fábricas e como o próprio estudo de casa, fizemos no site da Sabesp. Quando digo site, é o site físico, não o eletrônico.

O conjunto dessa metodologia, quando falo em aplicação é metodologia de implantação de um programa de uso racional e foram feitas diversas metodologias.

Ah! Perdão, aqui foi em delegacias também.

A ideia foi o desenvolvimento de algumas metodologias, depois os testes dessas metodologias, corrigi-las sob seu aspecto metodológico e ao mesmo tempo, nessa metodologia, as medidas e ações de economia de água, para que se pudesse mensurar e tornar algo não mais metodologia "filosófica", mas uma metodologia aplicada e mensurada.

A ideia à época era: se fechar as torneiras, vamos economizar água. É um aspecto da coisa. Nós pensamos: não, a torneira não precisa ser fechada, ela tem que ter um bom funcionamento, a saída de água adequada e consumimos menos. Essa é a ideia. Por quê? As torneiras tinham vazões diferentes. A ideia era que se tivesse menor vazão, com maior eficiência e com uma maior eficácia. Eficiência seria funcionar bem e etc. Eficácia, seria o caso de quando se fosse lavar as mãos, aquela vazão de água seria suficiente para lavá-la.

PERGUNTA - Até então havia norma para torneira?

SR. DOUGLAS BARRETO (IPT) - Não. Aí que é vem os aspectos daquele primeiro, a legislação a que me referi, inclusive, abordava a normatização.

PERGUNTA - Então não havia?

SR. DOUGLAS BARRETO (IPT) - Até então não havia para economizadores. Havia as normas para os componentes hidráulicos, não havia como prevista a economia de água e sim, como premissa do funcionamento.

Se uma torneira funcionasse com 0.3 litros por segundo, funcionava bem. 
Mas sabemos, se você fizer uma conta e multiplicar por dez segundos, já dá três litros de água. Três litros de água em dez segundos. É muita água. A torneira deveria funcionar bem com 0.1 litros por segundo.

É nesse conceito da economia de água, que as normas tiveram que ser adaptadas.

O marco que a gente fechou em metodologia, pode se afirmar que foi por volta do ano 2000.

Do ano 2000 para cá, nessa década, várias e várias ações ou programas de uso racional foram implantadas.

Por volta do ano 2000, o Programa de Uso Racional da Sabesp foi, de fato... É a questão de pegar o site, precisar direitinho, até 1999 e eu tenho uma marca redonda. Pode até ser 1998, mas é por volta de 2000, o Programa de Uso Racional da Sabesp, ganhou sua estrutura, dentro da própria companhia e passou então a abranger todo o entorno, todo o hall de clientes da Sabesp. Passou a ser um departamento, a Sabesp não possui departamento, mas era como se fosse, para promover o uso racional da água.

Por volta de 2000, lembro bem que começou a, aí já entre 2000 e 2001, tivemos um programa que foi no setor energético, um apagão de energia, que produziu um efeito interessante. À medida que reduziu a energia, também reduziu o consumo de água.

Como foram implantadas em todas as empresas de âmbito Estadual, de conservação, de racionalização do uso da energia, também saía, irmãos gêmeos, os programas de racionalização dos dados.

Mais um elemento para somar.

Já havia o projeto programa da Sabesp, mais o programa governamental, aí as empresas do Estado, passaram a ter programas de uso racional, de fato.

Temos, num primeiro estágio, incluindo o programa de Uso Racional da Sabesp que implantou em alguns sítios. Lembro-me bem que por volta desse ano, a USP implantou o PURA, até hoje, e esse marco, por volta do ano 2000, estou comentando, porque a Sabesp começou a ter uma tarifa de preço diferenciada para quem tem programa de uso racional, da água.

PERGUNTA - Como incentivo.

SR. DOUGLAS BARRETO (IPT) - Se você procurar lá, não sei se ainda tem, mas foi um marco. Então, ela vendia água para você mais barata, porque você tinha um programa de Uso Racional da Água, ou seja, consumia dez mil metros cúbicos mês, falava a quem 
estava implantando o programa, que daqui a três meses estaria com sete mil metros cúbicos. Ou seja, uma economia de $30 \%$. E o acordo era sempre maior do que $20 \%$ de economia e ela te dava uma redução na tarifa. Não recordo agora se era 20 ou $25 \%$, era uma redução expressiva. Porque é perene, uma vez que você reduziu, você passa sempre trabalhar naquele patamar então é um ganho muito grande para a companhia. Além do que todas as empresas que, ou adotaram programa que a própria Sabesp indica ou os programas similares elas na realidade tem um ganho econômico, um ganho de água, ganha neste sentido ela deixa de consumir e a companhia fica com mais água para atender a demanda da sociedade.

PERGUNTA - O resultado do PURA na USP foi muito satisfatório?

SR. DOUGLAS BARRETO (IPT) - Muito satisfatório. Da USP foi muito satisfatório. Ele é um exemplo que foi muito significativo, porque um campus universitário do porte da USP, o volume de água e os problemas que eles tinham no começo, que quando passaram á adotar esse programa de uso racional. Porque na realidade o programa de uso racional ele no começo achavam que você iria fazer uma série de ações e essas ações por si só durariam o resto da vida. Não, o programa da água, de uso racional da água trouxe embutido a questão do gerenciamento dessa água, a gestão da água, que antes não tinha a gestão da água, se consumisse pagava. A água passou a ser elemento a partir do qual tem agora um grupo, uma pessoa, alguns colegas que são gestores desta água. Então eles vendo a água tanto no seu consumo na sua utilização na manutenção dessas instalações, na conservação do bom uso.

PERGUNTA - Até então só tinha a gestão dos recursos, não tinha a gestão do uso?

SR. DOUGLAS BARRETO (IPT) - Não tinha, era só dos recursos. Era gestão exatamente. Hoje nós temos a gestão pela demanda, está certo, e antes nós tínhamos pelo consumo. Gestão não pelo lado da demanda, pelo outro lado, o lado do consumo mesmo. Nesse jogo todo de regras, metodologias, etc. a gente sempre teve em mente então, porque como eu falo agente, porque eu participei em 1994 dessa formulação, que o usuário, a educação faz parte dessa garantia. Quer dizer, não adianta eu trocar equipamentos, fazer uma série de ações cívicas, se o componente humano também não participa, não é alertado e não é 
conscientizado. Então o programa de uso racional tem essa componente muito forte também.

PERGUNTA - Seria a maior dificuldade no caso?

SR. DOUGLAS BARRETO (IPT) - Em alguns casos é a maior dificuldade, porque, um equipamento se troca e ele passa a consumir menos água, a pessoa não adianta. Ela tem que ser educada, reeducada, re preparada para essa postura de economia de água. A componente humana ou a componente social ela é muito importante, e ela tem que ser alvo evidentemente de campanhas educativas para que o programa mantenha o seu consumo dentro do que a gente previu. Então se troca equipamentos às vezes alguns equipamentos requerem um treinamento, por exemplo se você substituir um determinado edifício você tem bacia com caixa acoplada e você decide substituir o mecanismo que é de uma única descarga para um de dupla descarga, ou seja, ele dá carga completa de meia descarga, você precisa ter um treinamento desse pessoal. Ai você tem que ter um treinamento. Por quê? Porque se não ele vai ficar funcionando os botões erradamente e às vezes ele vai gastar até mais água. Então você precisa estar associado, se colocar alguma torneira economizadora um chuveiro com bloqueador ou temporizador que a gente chama, ou seja, hoje em dia em vestiários é muito comum apertar um botão e ele fica dois minutos, ai você aperta outro e ele fica dois. Você tem descargas de água de dois em dois minutos. Então você tem um banho, você consegue uma vazão, reduzir bastante do que um banho de seis minutos ou oito contínuos, porque dá tempo pro enxágue, etc. $E$ tudo isso tem a ver também, eu estou muito restrito ao projeto do edifício a componente mais é que tem a ver com o novo projetar, um novo projetar de ambientes para a economia de água, para economia de energia que até então não tinha. Nós temos uma doutrina educativa de projetos que nunca preocupou os projetistas. Então nós temos um problema muito grande que foi deparar com um passivo muito grande que é difícil, que consumia uma cidade, consumindo muita água com um novo paradigma que era economizar água. Então como é edifício novo, tinham os equipamentos e eu posso até educar as pessoas mas eu tinha um passivo muito grande, então o PURA tentou, há uma década que ta trabalhando para terminar esse passivo e garantir que os novos edifícios sejam econômicos.

PERGUNTA - Nessa década, olhando assim de longe há pontos positivos, negativos, o que poderia ter mudado nesse projeto com o PURA, aperfeiçoar? 
SR. DOUGLAS BARRETO (IPT) - Então o PURA da Sabesp eu diria que ele é o mais puro de todos. Porque ele foi o primeiro ele não teve nem contaminações que deturpassem nem que melhorassem muito. Ele nasceu de uma necessidade de uma interpretação que o bem era finito e que os esforços deveriam caminhar para ele. Ele tem uma estrutura inicial muito boa. Ele foi melhorado, ele foi aprimorado porque a medida o PURA é da Sabesp. Porque ele passou a atender demandas maiores, antes no início eram poucos prédios, os prédios eram grandes e muitos localizados. Hoje ele já está mais espalhado, já está pegando quase todas as escolas do município, os hospitais já quase todos. E o que aconteceu? Como isso é uma coisa boa, e voltando em 2001 com essa necessidade de ter programas em várias instancias você teve então um florescimento de um mercado de PURA. Então nós passamos para uma outra visão do PURA que foi a visão do mercado atendendo. Então tem empresas que criaram modalidades diferenciadas de PURA, que não era mais a própria Sabesp. A Sabesp implantava um PURA, a equipe era contratada para fazer um diagnóstico, dava algumas propostas o prédio implantava as propostas, no final eles avaliavam se estava tudo em ordem constatavam a redução no consumo e davam aquela redução de abatimento no valor da água. Isso foi o principal. Quando passou para o mercado, para as regras do mercado, as empresas começaram a ter várias modalidades de PURA, cada qual com o seu diferencial mercadológico. E não mais importava se a Sabesp vendia água mais barata ou não. O que importava é que a economia ia ser de fato e essa economia uma vez implantado um programa e uma vez ele sempre sendo observado é uma redução para sempre. Ou seja, se você consegue reduzir 35\%, é 35\% multiplicado por infinitos anos. Se você pegar ali dez anos, dá tantos milhões, 20 anos, então é um ganho perene. E as empresas então, as particulares cada qual para ganhar esse mercado alterou o PURA, melhorou, inseriu coisas que a gente não imaginava.

PERGUNTA - Os fabricantes também desenvolveram novos produtos, novos equipamentos?

SR. DOUGLAS BARRETO (IPT) - O PURA da Sabesp teve sempre uma parceria com os fabricantes. E eles sempre atenderam essa demanda. Ou seja, na época, sempre que agente participava como contratado e depois conheço toda a equipe do PURA e sempre que os fabricantes foram chamados agente participava como IPT e eles sempre desenvolveram os equipamentos para atender o mercado. Não só do PURA mas do mercado aberto. Então nós precisávamos de um arejador especial para uma torneira de cozinha, que promovesse uma vazão adequada o pessoal se empenhavam para 
desenvolver um produto e vendiam aquele produto como economizador. Então os grandes fabricantes os médios e os pequenos começaram a criar linhas economizadoras de água. Tudo muito bem ajustado, muito bem articulado com o PURA da Sabesp que suplantou um pouco. O que estava me referindo são empresas que batem em um determinado condomínio e vendem o programa. Eles usam as torneiras que agente sugeriu, eles comparam no mercado, eles usam as normas que agente desenvolveu e vendem. Então existem empresas especialistas só em PURA. Não sei te dizem como é que está mais, mas eu sei que já teve.

PERGUNTA - Não, ainda tem.

SR. DOUGLAS BARRETO (IPT) - Ainda tem, não é?

PERGUNTA - Tem empresas trabalhando, em edifícios corporativos, numa escola, em fábrica.

SR. DOUGLAS BARRETO (IPT) - É o que aconteceu, é assim, quanto o PURA. O que está tendo agora é uma demanda de mercado que ta tendo que é medição individualizada. Ela faz parte de um programa de uso racional, à medida que você quando tem uma medição unitária do consumo de uma unidade e essa unidade você sabe que consome 18 metros cúbicos, então você vai pelo lado do ajuste. Então você vai individualizar daquela família 18 metros cúbicos. A do outro é 22 e do outro é 30 metros cúbicos, cada qual paga exatamente o que consome. O conceito de condomínio no Brasil era de uma entrada única "rateada" por todos. Então tinha aquele desperdiçador e o economizador.

PERGUNTA - Pagava pelo desperdiçador.

SR. DOUGLAS BARRETO (IPT) - Então porque que um cara economiza, o outro não gasta. É fato cultural o que eu estou falando da componente social, é importante, depois você tem componentes tecnológicas que são os equipamentos e depois tem o que eu chamo de componente metodológica, que é aquela que junta os dois (equipamentos e pessoas), a metodologia. Que vai lá, que horas que põe e quando põe. Essa metodologia que é relativamente simples, mas ela é articulada, ela prove resultados. E têm várias 
maneiras, cada um vende o seu. E ai a disputa de mercado o IPT não entra nisso ai. Nós já fizemos alguns aconselhamentos, há muitos anos atrás, agente não disputa esse mercado, que é hoje em dia o do programa do uso racional e o de medição individualizada. Agora os dois estão quase que, falar de um é o mesmo do outro e falar do outro é o mesmo de um.

PERGUNTA - É isso é muito bom por separar, ainda mais que...

SR. DOUGLAS BARRETO (IPT) - Isso faz parte do espírito do programa do uso racional para você pagar pelo o exatamente pelo o que você consome. E pagar pelo o que você consome é a medição da unidade. É uma individualizada.

PERGUNTA - E agente fala um pouco da economia que teve aqui na USP equivale mais ou menos pela implantação das unidades. Não sei, só um...

SR. DOUGLAS BARRETO (IPT) - É que esses valores, bastante a economia na USP foi exemplar. É um caso que você pode até procurar os valores mais precisos, mas foi exemplar. Tanto que a UNICAMP também implantou, uma universidade Santa Maria lá do Rio Grande do Sul também implantou. Eu também não me lembro de todos os campus universitários, mas lá eles implantaram porque a economia foi brutal. Foi muito bom.

PERGUNTA - E essa tecnologia em relação ao mundo, como que o Brasil se coloca, já que o senhor esteve em Portugal, enfim, como que o senhor vê o PURA agora o nosso hoje, a PURA a Sabesp no contexto mundial? Nós estamos avançados, nós ainda estamos muito a quem?

SR. DOUGLAS BARRETO (IPT) - Então. É os programas de uso racional existe no mundo todo, cada um com um nome. Nos Estados Unidos é Water White, na Europa é Eco Eficiência, tem nomes variados. Mas o nosso PURA como ele foi, desde 1992, muito equilibrado nas consultas, tanto no Hemisfério Norte, pro lado Americano como do lado Europeu, nós temos uma boa sintonia de normal dos equipamentos, nós não estamos nada devendo, estamos ali no mesmo patamar. O que nós podemos ter em algum momento ou não é que as nossas cidades, elas são muito grandes. Qualquer ação que agente vá fazer é na casa de milhar. $E$ milhar eu diria de cem milhares, não é de dez milhares. E você tem 
localizações na Europa que tem dez mil casas, quinze mil casas, quer dizer, são quarenta mil habitantes cinqüenta mil habitantes, é uma cidade razoável. Aqui nós temos um pedaço de um bairro com essa população, segundo com um número de casas. Então quer que o que nós temos aqui é uma amplitude maior, um espaço maior e não tem como não usar nenhum programa de uso racional, nós temos que usar. Mas não devemos nada para eles, os equipamentos que lá tem, aqui existem. Talvez, os de lá, um ou outro desenvolvimento um pouco mais aprimorado diria que aqui chegaria um pouco defasado, só não está no mesmo time, mas em termos de conceito e aplicação nós somos iguais.

PERGUNTA - Nossa engenharia não tem nada a dever com os outros?

SR. DOUGLAS BARRETO (IPT) - Em termos de engenharia não, nós temos ai um ganho de escala.

PERGUNTA - Dificulta um pouco?

SR. DOUGLAS BARRETO (IPT) - Não é que dificulta às vezes você tem que incorporar alguns aprimoramentos que o produto fica um pouco mais caro e temos outra realidade de país. Quer dizer, para essa economia existir de fato, ela tem que ter uma escala muito grande, mas é muito caro e a sociedade toda não consegue pagar, só uma pequena parcela, então fica num escalonamento primeiro faz um produto, depois ele abrange mais um pouquinho, depois mais um pouquinho e depois a escala toda. O que eu quero dizer é o seguinte em termos americanos, europeus você tem uma sociedade um pouco mais igualitária do que a Brasileira. Então você acaba tendo consumidores que não conseguem comparar uma coisa durante vinte anos e outros que conseguem comparar cinqüenta vezes mais do que eles. Na Europa você já tem e nos Estados Unidos também uma faixa mais homogenia. Então os programas já...

PERGUNTA - Atingem mais gente.

SR. DOUGLAS BARRETO (IPT) - Atingem mais gente. São reprodutíveis em vários locais. Eu quero dizer que às vezes um programa de uso racional aqui em São Paulo é fantástico, perfeito. Mas se você pegar algumas comunidades do agreste nordestino não tem água, 
quer dizer. Mesmo em São Paulo você tem absurdos aqui a serem dominados. O que eu quero dizer é que às vezes os programas têm que ser adaptados as suas realidades e as suas micro problemas a gente tem que entendê-lo. Como você também, a ideia é você, vende uma ideia, não tem valor monetário você vende no sentido de convencer as pessoas e depois está agregado a alguns componentes tecnológicos. Esses aí sim, são adquiridos. Então o convencimento de uma ideia, ela esbarra no valor do componente. Então é uma equação que você tem que parear. Então às vezes não da para tem um programa de amplo espectro que nem nós gostaríamos, ele tem que ir caminhando. Então substituição das bacias. Nós no IPT trabalhamos durante muitos e muitos anos que o consumo saísse de 1988 doze litros, para chegar por volta de 2002 a 2004 a seis litros. Conseguimos num curto espaço de tempo que reduzisse $50 \%$.

PERGUNTA -- 50\%.

SR. DOUGLAS BARRETO (IPT) - 50\%. Então isso é importante, porque tanto faz o valor do produto ele vai ter que consumir aquele valor, aquele consumo de água. Isso já é uma coisa muito importante. Agente tiro a componente sobre valorização ou agregar valor, que na realidade não existe. Todo mundo, a ideia é que o equipamento funcione com pouca água. E não é porque ele consome pouca água que eu cobro mais caro o equipamento. É porque é um indutor ao contrário. Como quem, por exemplo, você pega uma bacia que gasta três litros, ela custa mil reais e uma que gasta seis litros ela custa cem reais. Como a nossa população só consegue comparar a de cem, não vou nunca ter uma economia por causa da diferença de escala.

PERGUNTA -- É lógico.

SR. DOUGLAS BARRETO (IPT) - É lógico. Tem que trabalhar nessas duas componentes.

PERGUNTA -- Vai diretamente à questão cultural mesmo.

SR. DOUGLAS BARRETO (IPT) - Afeta também a. Eu diria assim, a componente social. A cultura você consegue trabalhar muito bem, mas quando você vai pro socioeconômico, e o social, ele é dividido pelo poder econômico que tem as pessoas que formam os seus 
núcleos sociais. Se essa categoria econômica não consegue, você até colocar cultura, mas ela vai ter que sacrificar muita coisa. E uma componente que você tem que dosar direitinho. Então, você tem componentes acessíveis e a cultura sendo propagandeada, sendo divulgada. Ao mesmo tempo em que você tenha produtos que possam ser acessíveis ou você tem uma reviravolta econômica que o Brasil passou pelas últimos oito, doze mais ou menos anos, ele vem subindo pontinho a pontinho no bem estar econômico do país.

PERGUNTA - Fale um pouco mais dessa questão da tecnologia e o componente social. Esse é um ponto muito forte na questão do PURA, quer dizer, nesse momento lá fora tem a facilidade de você disseminar uma tecnologia porque a sociedade tem uma capacidade de absorção maior dessa tecnologia. Financeiramente.

SR. DOUGLAS BARRETO (IPT) - Sim, ela tem uma capacidade maior, os mecanismos legais, normativos eles são articulados simultaneamente. Então à medida que entra um equipamento ele pode passar a ser uma exigência que ta ligada com a norma, que ta ligada com a lei, que está ligado com o código de obras, e é tudo uma cadeia que começa a funcionar rapidamente. Aqui no Brasil essa sintonia nem sempre existe. E lá no exterior, alem da sintonia, tem o produto que é feito em função do poder econômico das pessoas. Então é desenvolvido compatível, porque ele quer criar mercado. Então ele tem essa componente. No Brasil o que acontece, nem sempre isso é articulado simultaneamente, e você tem então a componente tecnológica, ela ta sempre sendo desenvolvida, o homem está sempre dando soluções tecnológicas para aquele problema. A tecnologia, o acesso a essa tecnologia é que vai dizer, que vai depender, perdão, um conjunto de elementos. $O$ quanto esta tecnologia custa, quando e onde ela vai ser incorporada, em que momento ela vai ser disponibilizada e a que custo. Então se você pensar, agente fala, há vinte anos um celular, tava numa caixa de sapato e custavam 4 mil dólares. Hoje em dia, ou seja, tem um tempo de maturação e tem um tempo de absorção. Todo componente tecnológico. E na parte da economia de água, eu diria que nós estamos no mundo todo refinando as tecnologias. Então vai ta sempre evoluindo. Seja na bacia sanitária numa torneira, um chuveiro um aproveitamento da água hoje em dia, como você já racionalizou o uso, uma década, duas décadas, então você já tem a cultura da economia de água. Você já tem os PURAS, então você já tem equipamentos, então o que ta acontecendo é que o desenho dos objetos que consomem água dos edifícios eles já estão adaptados já estão com os componentes economizadores, as pessoas já estão pensando em economia já tem medição individualizada então essa etapa aqui já ta, ai eu falo ta bom. Como isso aqui significa uma 
redução no consumo, eu tenho então um tempo, eu falo assim, essa estação de tratamento de água virtual ela vai ser então distribuídas para outros pontos e um momento vai ta todo mundo com torneira, todas as casas e tal. Quando você chega nessa região você tem que passar para outra modalidade. Como a água é um bem finito e a população ta crescendo a urbanização crescendo, nós ainda temos algumas regiões com déficit de água muito grande. Adensamentos urbanos meio descontrolados.

PERGUNTA -- Aonde tem muita água tem pouca gente?

SR. DOUGLAS BARRETO (IPT) - O desequilibro no Brasil é que onde nos temos, que é interessante, o Brasil aonde tem um maior volume de água doce aonde quase não tem população. Em contrapartida, aonde tem um maior volume de água salgada não tem água doce, tem água salgada que é todo o litoral, to falando uma coisa de $50,60 \mathrm{Km}$ com as grandes cidades. As grandes aglomerações e não tem água tanto quanto se precisa para essa região. Porque é uma região litorânea e as bacias se formam normalmente da serra aqui, da serra do mar, a mata atlântica e toda aquela região costeira e vai para dentro do país. Essas bacias vão ser fortes, vão ser ricas em água quase na faixa dos $200 \mathrm{Km}$ do litoral, e aonde tem as cidades menos populosas. As cidades mais populosas estão nessa região. E ai não tem água mesmo. Então você tava falando, os programas de usos racionais que são fundamentais evidentemente, e depois nos vamos, mantida e não vai ter nenhum cenário que altere. São Paulo não se "desurbanizar". Não tem como "desurbanizar", o que vai acontecer é adensar só. Mas o urbano já atingiu ai o seu máximo,. O que vai acontecer é ela vai adensar, abrir espaço, avenidas, verticalizar e evidentemente demandar mais água. Porque o adensamento vai requerer a água. Então você vai ter uma economia em todos os prédios, todos os edifícios e vai passar a utilizar as fontes alternativas. Nós temos os subsolos, tirar água do subsolo, uma grande fonte. São Paulo aqui tem algumas zonas boas, outras não. E depois passar a usar água de chuva e depois ate água de reuso de esgoto. Isso é uma tendência. Do ponto de vista tecnológico, estamos desenvolvendo essas tecnologias para poços profundos, para analise de disponibilidade versus adensamento. Onde está a água. Evidentemente que o governo do estado tem algum plano diretor que induza então a você precisar montar a empresa que precisa de muita água, não ter em São Paulo, vai ser próximo ao aqüífero do guarani. Onde esta o aqüífero do guarani? Está a $350 \mathrm{Km}$ da capital, então algum pólo de desenvolvimento tem que ser criado ali. Porque se você precisar de água aqui não da mais. Ou vai dessalinizar ou vai aonde tem. 
Então talvez seja uma tendência esse redesenho de ocupação de onde tenha água no interior do estado de São Paulo e do país.

PERGUNTA -- O senhor tinha comentado por exemplo assim,tudo bem, a bacia teve uma redução de 50\% em 15 anos, o consumo. Nós tivemos as torneiras. Mas por exemplo a válvula de duplo comando que e aquela com os valores do fluxo de água para rede de sólidos o outro para resíduo liquido, não vingou ou tem uma dificuldade de disseminação.

SR. DOUGLAS BARRETO (IPT) - A válvula de descarga ou a...

PERGUNTA -- A válvula de descarga. Mesmo a válvula, a caixa acoplada, as duas, de duplo comando, agente não vê isso muito disseminado, não vê um uso assim como aconteceu com a torneira automática, como aconteceu com a válvula de redução de vazão.

SR. DOUGLAS BARRETO (IPT) - É eu coloco assim, é que na escala dos equipamentos hidráulicos aqueles que respondem e aceitam mais rápido, e tem aqueles que se culturalmente assimila e se maneja mais rápido e vamos ali. É uma conjugação entre a tecnologia a sua operação e o seu usuário. Tem que ter ali um acordo, tácito, que aquilo vá funcionar. Evidentemente que as primeiras torneiras de acionamento automático, não funcionavam a contento. Geravam mais problemas porque, a cultura era de girar não de apertar. Você pega ai por volta, às torneiras, aparecendo por volta de 1800, são quase 150 anos Vamos dizer 150 anos que o ser humano aprendeu a girar uma torneira, como é que em um ano você quer que ele aprenda a apertar a torneira. Então é complicado. Essa componente que agente trabalhou desde o começo. Falou olha, não é porque é a torneira, é que a cultura tem que mudar o homem para algumas coisas. $E$ isso rebate nos novos equipamentos. Sempre vai haver essa, há, não está disseminado. Calma. O que isso afeta com a característica de como o homem interpreta aqueles sinais daquele mecanismo que ele se adapta e funciona. Isso é muito interessante porque eu cheguei a presenciar cenas interessantíssimas. Aquela de apertar ainda é uma razoável, que se tenta de qualquer maneira. E aquela que é uma eletrônica. E aquela que é de acionamento no pé que ninguém via no chão. Ai tinha que botar a "eletrônica aproxime as mãos", mas aproximar de onde? Porque ele não pode por, se ele colocar bem próximo de onde de onde tem que aproximar a mão, fica dentro da pia. E aquilo saia e entupia. Então. Tem todo um quadro sinótico a ser trabalhado. Para que o homem interpretasse aquele signo e se conseguisse 
utilizar correto. Então isso da uma enquête. Que nós chamamos ai, aquele que não dissemina, não pega, demora. Mais dois, três, quatro anos depende de como for. Com relação a esses dois, em especial a válvula de descarga de duplo comando, e caixa acoplada para bacia com duplo comando, é a mesmíssima coisa. Quer dizer, todas as vezes que você vai ter um acionamento, tem um ponto único, é um botão único, é uma coisa única. O outro também. Você entra no banheiro, lá consta uma gotinha pequena, uma gotinha grande. É, não está no imaginar das pessoas como ela reagiu naquilo lá. Então o que acontece, começa a ter reclamações, reclamação de usuário, ou, o cara deixou o banheiro sem dar descarga, ai não usa. Começa a reclamação. Ai o que acontece, para evitar isso é muito mais fácil tirar aquela lá e deixar a de um comando apenas. Quer dizer para quem ta sofrendo o problema. Quando você tem um programa já um pouco mais elaborado você começa com campanhas educativas. Então você coloca num Box, uma campanha educativa. Aquele Box faz duas descargas o botão de uma gota tem um cartaz enorme, ai depois troca o segundo, ou seja, você tem que...

\section{PERGUNTA -- Educar.}

SR. DOUGLAS BARRETO (IPT) - Educar. Para a tecnologia. A educação para a economia de água é um assunto. Isso ai vai educar para aquela tecnologia que ta chegando. A teve um caso inusitado que era uma torneira que era um pistão uma bola assim, e todo mundo girava, apertava e o negocio era só para fazer isso.

PERGUNTA -- Só para virar ao lado?

SR. DOUGLAS BARRETO (IPT) - Não, bater, para qualquer lado. Só que ninguém conseguiu. O pessoal batia, o pessoal girava e não saia água. Então, e o outro era só de apertar, e o outro era só de aproximação. Então você imagina três alternativas para sair água de uma torneira, para um sujeito que sempre girou.

PERGUNTA -- Ou muitas vezes nem teve acesso a esses comandos.

SR. DOUGLAS BARRETO (IPT) - Não, está vendo pela primeira vez. 
PERGUNTA - Ele não teve acesso a uma torneira por exemplo. Muitas vezes ele vem do sertão.

SR. DOUGLAS BARRETO (IPT) - Não, não, isso é pior ainda. Isso é pior ainda. Essa é a cultura com o urbano. Se levar em conta a cultura com choque urbano é pior ainda. Eu estive no exterior recentemente e vi algumas torneiras e a maioria era de apertar mesmo essa de

acionamento hidromecânico por que, é hidráulico. Algumas de posicionamento, mas assim, não tem mais nada, não tem nenhuma informação. Já está completamente assimilada. Culturalmente todo mundo que entra ali já sabe que a torneira se for daquele jeitinho é para por a mão e se for á outra é para empurrar. Não há duvidas. Por quê? Porque deve ter feito campanhas deve ter tido coisas desse tipo, há muitos anos atrás. As bacias sanitárias no Brasil eu já tenho visto alguns, shopping centers eu não vi, mas já vi algumas empresas comerciais em prédios, onde já ta lá bacia com dois volumes de descarga. E a campanha é feita com os funcionários dessas empresas. Eu como visitante, tive acesso ao sanitário não tive problemas porque sou um conhecedor, mas eu até comentei com o gerente que eu fui lá, coloca um carta Zinho ali pequenininho "esse banheiro está equipado com dois comandos", porque um visitante, e nem sempre conhece, ele falou, puxa, bem lembrado. $E$ parece que colocaram mesmo. Para visitantes que é um...

PERGUNTA - O funcionamento depende do consumidor.

SR. DOUGLAS BARRETO (IPT) - E eu coloquei inclusive para ele propagandear. Falou olha essa empresa tem consciência da economia de água e esse banheiro está equipado assim e coloca um símbolo, com uma gotinha ou então aperte aqui, se for só liquido e aqui se tiver dejetos junto. Acho que foi colocado.

PERGUNTA -- Voltando a visão macro de saneamento. A Sabesp possui o Pura que é um dos programas estruturantes da Sabesp juntamente com o projeto Tiete, recuperação dos rios Tietê e Pinheiros, o Programa Vida Nova, também conhecido como Mananciais, responsável pela proteção das represas Billings e Guarapiranga, e o Córrego Limpo, que tem como objetivo recuperar os córregos de São Paulo. Gostaria que o senhor me passasse sua visão sobre esses projetos do ponto de vista ambiental, tecnológico para a sustentabilidade da RMSP? 
SR. DOUGLAS BARRETO (IPT) - Então vamos lá, o programa de uso racional da Sabesp, ele tem toda uma estrutura, foi montado pro lado do fornecimento de água. Então a Sabesp têm mananciais tem lá suas captações, suas estações de tratamento e tem sua distribuição. O consumo que estava exagerado tem os programas de uso racional. À medida que diminui a absorção, a água aqui, toda essa cadeia para trás fica aliviada, opera bem, trabalha bem, porque a Sabesp não só trabalhou com a parte de consumo de água pelo PURA, mas combateu as perdas. Porque não adiantava nada economizar água se o usuário e a Sabesp estava com perdas na rede, também atuou um programa de perdas. Então ele teve toda uma cadeia, não é? E ai, nós chegamos aos mananciais. Acontece que toda esta água que em 2002, ate agora 2008 eu acredito de seja entorno de 75 a 80 metros cúbicos por segundo de água tratada que entra em São Paulo. Então, 85 metros cúbicos por segundo, para equilíbrio de massa, o que entra sai. E a Sabesp não coleta $100 \%$ do esgoto, ela pode coletar quase 100. Mas ela coleta e não trata $100 \%$. Mesmo assim nós temos ai os seus patamares. Acho que a Sabesp está coletando $80 \%$ e tratando 60\%. Daí é fácil ver no site esses números, mas não são $100 \%$ ponto a ponto. Ela tem $100 \%$ de entrada de água e um restante que volta por diversas maneiras. E ai é interessante o foco dos programas complementares. Porque essa água ela volta na forma de esgoto, a água utilizada, a água servida. E como ela não consegue pegar 100\%, ela, essa água vem por vários caminhos. Então ela vem por onde? Ela vem pelo Rio Tietê, vem pelos córregos e ela às vezes vai pros mananciais indevidamente. Sendo que alguns mananciais têm um problema de ser um manancial provedor. Então se teve ocupação irregular com descarga de esgoto nesse manancial. E ele é um manancial provedor. Então cuidar desse manancial é importante porque elimina descarga de esgoto e preserva a antropização na borda deles. Se não me engano o plano é ambicioso, é interessante de recuperar as margens dos mananciais comprometidos, coletando esgoto, tirando o lixo, e uma serie de atividades. Então essa é importante. Então ali ele está eliminando ou diminuindo muita a descarga de esgoto, de dejetos sólidos de contaminantes, faz com que a água fique com melhor qualidade que seja. A água desse manancial fica com uma qualidade um pouco maior, significa que a estação de tratamento não vai demandar tanto produto e a água vai se chegar melhor e é um ciclo, não é? Como eu estou gastando menos, e ai você gastando menos lá na produção. O Tietê, ele é um projeto que ele na realidade falando córrego limpo, também, é por que eles são todos tributários do Tietê, na cidade e vem com esgoto e, além do esgoto, pelo fato dessa população irregular ocupar os ribeirões, acaba carregando muitos sólidos. E esses sólidos, com esse esgoto, diminuíam a velocidade e iam sedimentando. E quando você sedimenta você tem um processo aeróbio e anaeróbio de digestão de lodo que isso daí começa a 
fermentar e formar aquele odor, não é? Não só fermenta mas tem uma serie de processos biológicos ali internos e começa a ter então uma água de cor, uma baixa DBO e DQO e acaba tendo odor, cor, não é? E principalmente odor e cor. Então, quando ele atua no córrego limpo, nos mananciais, sem essa preocupação, quando vão a córrego limpo seria parado de carregar essas coisas e à medida que você oxigena essa água que vai ser tributaria do Tietê, ela já entra com uma qualidade melhor. Hoje ela entra com uma qualidade pior carregando sólidos e esgoto. À medida que você limpa um córrego, desocupa suas margens tem essa oxigenação. E tem também a eliminação de dejetos, de alguma maneira, ou seja, essa população ribeirinha vai parar de jogar porque, vamos ter que fazer aqui um coletor, um receptor, alguma coisa de esgoto. Ou seja até propor uma coleta de esgoto, encaminhar para uma estação de tratamento. E quando todos esses tributários chegaram, chega ao Tietê, que é o nosso maior, rio urbano, maior rio urbano, eu acho que em extensão não é, lá tem vazão, mas em extensão é com certeza um dos maiores rios urbanos do país. Mas totalmente é, com os seus tributários com esgoto, contribuindo com esgoto. Então nós tivemos algumas etapas do projeto Tietê, se não me engano, começou na década de 90, 1990 se não me engano, nesses 20 anos aí não. Praticamente, várias etapas. A disposição realmente não se faz de uma hora para outra, leva muito tempo. E eu me lembro bem da década de 90, que teve uma ação conjunta da CETESB e Sabesp. A CETESB trabalhando com todas as empresas que poluíam, poluição química bruta. Colocou que todas as empresas deveriam entregar uma qualidade de esgoto na saída. A Sabesp passou a ter um mecanismo de cobrar pela qualidade desse esgoto e não mais pela quantidade, ou seja, se você entregar um alto índice de esgoto com contaminante $\mathrm{X}$ e $\mathrm{Y}$, você vai pagar a tua conta mais $\mathrm{n}$ vezes. $\mathrm{E}$ era bem alta. Então as empresas ao invés de ficarem pagando tanto, eles instalaram estações de tratamento local elevando a qualidade desse esgoto, ou seja, melhorando o efluente que veio pro Tietê. $\mathrm{E}$ isso tirou uma carga muito grande do Tietê no seu trecho paulistano, e o que tem, porque que não chegou ao finalmente. Porque tem uma grande poluição vinda dos esgotos domésticos, que vem pelos pequenos córregos e tributários. Hoje em dia você passa num ao longo do rio Tietê e está escrito lá, galeria de águas pluviais e o outro é córrego, tem uns nomes. Aquela que é galeria, você pega o córrego está saindo um fio de água, e o que é a galeria de águas pluviais, está saindo um rio de esgoto. Então tem alguma coisa, essa água desse córrego está sendo interceptada, está carregando muitos sólidos e ela está sendo absorvida, está havendo alguma coisa, enquanto que a rede pluvial que era para servir à água de chuva, estão todos jogando esgoto. Então o que acontece, ainda, é que o Tietê deve estar na fase agora de melhorar essa interceptação e o caminho é realmente pelos córregos. Interceptando nós córregos, mais estações, aliás, ao longo do Tietê tem ai os coletores prontos, foram feitos alguns coletores prontos para não descarregar no próprio 
Tietê, coletas das redes de esgoto, mas como a poluição vem pelos córregos então tem que agir no trajeto dos córregos. Quando o córrego está aberto, dá para fazer um córrego lento, o problema é que muitos córregos de São Paulo estão totalmente escondidos, e sem acesso. Então digamos que vai mais um pouco ainda para limpar de vez a poluição.

PERGUNTA -- Haveria de ter a sinergia, que um, por exemplo num PURA que junto ao fabricante, Sabesp, corpo técnico, prefeitura e empresas. Quer dizer, no caso desses programas seria a prefeitura, com a questão de ocupação irregular, outras secretarias, o governo estadual, federal, isto é uma movimentação geral. Não só uma empresa de saneamento?

SR. DOUGLAS BARRETO (IPT) - É. Nesses casos o PURA tem um âmbito do edifício, então eu digo, o PURA tem um endereço certo, por que ele procura o edifício, um conjunto de edifícios, uma parte da cidade. Mas são pontos onde você atua. Quando você fala de Tietê, mananciais e córrego limpo, nós estamos falando de uma coisa muito aberta, porque às vezes a gente não sabe o que chega ali e por aonde que chega. Então precisa de articulação municipal sim, as leis de uso e ocupação do solo tem que ser garantidas. É necessário se ter um mapeamento de todos os canais de drenagem de água de chuva e os canais de drenagem dos córregos. Saber onde estão esses canais, que lugares estão. Precisa ter a Sabesp, sim, evidentemente precisamos ter os coletores prontos, tem que ter os pontos de descarga. Precisa de corpo técnico, também precisa, porque, eles vão mexer em situações que vão alterar com alguma norma, alguma legislação em vigor. Precisa ter um corpo técnico. E também um corpo político, é o principal também que seja governante tem que está de acordo com o que tudo isso que a gente vai mexer.

PERGUNTA -- Falando a questão do corpo técnico e o uso ocupacional do solo. Muitas vezes quem faz a legislação do Plano Diretor, pode até ser o corpo técnico, mas como vai a uma Câmara de Vereadores, vai para um, enfim, aprovar essa lei. Eles torcem tanto pelo corpo político e econômico que acabam até fugindo do corpo técnico, certo?

SR. DOUGLAS BARRETO (IPT) - É, esse é o risco que nós temos que é a casa de, que aprova os projetos, o nosso legislativo em âmbito municipal, ele pode, ou às vezes, muda um pouco a ideia original que seria de um determinado teor, que lhe é. Ele tenta acomodar os interesses como representante do povo. Mas o que acontece, muito desses 
representantes contam com uma boa interlocução do meio técnico. Hoje em dia não há uma proposta de lei que não tenha uma comissão e que não mande a um instituto de engenharia, que não mande para uma entidade de proteção ambiental. Por que é fadado a ter problemas. E ninguém quer ter a fama de ser um detrator do meio ambiental, nem do meio urbano. A ideia é, e isso tem funcionado cada vez mais, que esses projetos de lei acabam tendo esse apoio, aliás, eles usam desse apoio para que esses projetos de lei não sejam mais repicados e eles recebam uma fama qualquer.

PERGUNTA -- Então o senhor está otimista assim, certo? Olhando esses programas, olhando o Plano Diretor, olhando São Paulo.

SR. DOUGLAS BARRETO (IPT) - É, ai a visão otimista é assim. Eu sou otimista se não, não dá certo. O que não dá certo assim? São Paulo, vamos falar de São Paulo. São Paulo é um município que ele de simples, de quase, nenhuma importância no século 18 , ele entrou ao século 20 como de maior importância. Ou seja, ele saiu do nada pro tudo. E por que ele saiu? Saiu por essa pujança, por essa mudança, por esse crescimento. Evidentemente que 200 anos foram suficientes para sedimentar muita coisa, muita coisa errada saiu, muita. Abusos saíram de uma maneira ou de outra. Nós maltratamos muito a natureza circundante estamos pagando por isso. Hoje temos ilhas de calor, temos falta de água aqui, temos problemas de energia acolá, temos trânsito caótico, tudo por esse nome, desse ser primeiro. Acontece que, eu acredito que esses, a interligação desses programas eles tão tentando resgatar uma qualidade de vida que é necessária para todos. Então não tem como você imaginar que 19 milhões de habitantes agora, vão ficar desgostosos, vão lá pros paraísos nordestinos ou sulistas, ou centro- brasileiro. Não tem 19 milhões, não dá para mudar 10\% da população, uma logística, certo? O que vai acontecer é uma acomodação e uma melhoria, porque, à medida que as pessoas vão para outros centros de um pouco melhor qualidade de vida acabam querendo que aqui assim o seja. Então esses planos tendem a ser cobrados e eu digo isso porque o rio Tietê é um rio fétido como todos os seus problemas, mas são 20 anos que estamos tendo investimentos para recuperar. Pode ser que nos próximos 20 , o rio fique perfeitamente recuperado.

PERGUNTA -- E em relação a esse cenário... 
SR. DOUGLAS BARRETO (IPT) - É eu estou otimista nesse cenário, a cidade vai ter que melhorar, está certo, não sei como? Esse compromisso de deixar uma cidade melhor para nova geração ela está muito forte. Esse sentimento, na população como um todo. Mas nós sabe que essas melhorias elas não vem em um ano ou dez anos, realmente vai demorar ai, algum tempo. Mas as iniciativas estão sendo tomadas e as doações estão sendo feitas. Então eu vejo assim, eu tive o PURA, eu tive o uso racional de energia elétrica, eu estou tendo a incorporação de novos aparelhos, ações de limpeza de córregos de rios, eu tenho a preservação de mananciais, eu estou tendo energia solar entrando no site urbano. Então eu estou tendo aí uma série de ações, pode até parecer, dispersas no espaço e no tempo, mas todas estão tentando resgatar a São Paulo, uma qualidade de vida que ela perdeu já há mais de 50 anos. E eu acho que ela vai, numa expectativa de longo prazo, se recuperar. Grandes cidades no mundo passaram por isso e recuperaram. O problema de São Paulo é que o porte dela é muito grande, e os problemas sendo grandes demandam muito dinheiro, muito investimento e o prazo nem sempre é...

\section{PERGUNTA -- A contento.}

SR. DOUGLAS BARRETO (IPT) - É. Eu digo assim, não dá para ser na expectativa de uma vida. Da para ser parte da vida, se atingir algumas coisas. Eu estou comentando isso por que, você tirar a carga poluidora do rio Tietê em 20 anos de atuação, ele tem bons resultados. A língua negra que eles chamavam de poluição a língua de poluição, ou a pluma de poluição do Tietê, que eu acho que estava $170 \mathrm{Km}$, agora ta em 70 , já reduziu bastante. Isso é importante, você trouxe qualidade de vida, o que você mexeu aqui, você pode verificar que foi a mancha de poluição recuar tanto. Evidentemente que ela vai recuar mais. Até uma hora em que ela deixe de existir, essa é a nossa ideia, mas até lá vai ter muita coisa a ser feita, que é uma ocupação de 19 milhões de habitantes, demanda ações de longo prazo de grandes...

PERGUNTA -- Quer dizer não é um absurdo, ainda ter como método, como objetivo um Sena, um Tâmisa, Seul, por exemplo?

SR. DOUGLAS BARRETO (IPT) - Não, não. Eu acho que vai ser possível sim. Eu sempre parto dessa premissa, vai ser sim. Lógico. Há uma mudança de patamar de pensamento do brasileiro. Hora que essa mudança de patamar também começar a ocorrer, todas essas 
medidas começam também a ser efetivas Quando eu falo mudança, é nosso padrão cultural aqui é muito baixo. Não tem jeito. Você, baixa escolaridade, baixa renda, as necessidades do homem ali são na sobrevivência ainda $E$ não se importam com a qualidade. Eles querem sobreviver, não importa que qualidade. A hora que eles saírem desse patamar para falar: "Eu quero sobreviver com qualidade, eu quero viver...", perdão, "com qualidade." E isso com um maior número de pessoas, aí sim as coisas começam a acelerar mais, acelerar e se manter. Como o nosso estagio ainda é sobreviver, por grande parte da população, então algumas dessas medidas demoram mais tempo para serem visíveis. Nós vamos fazer uma limpeza de córrego e o pessoal joga sofá, joga geladeira dentro do córrego. Por mais que eu tenho o corpo técnico e o aparato do estado recuperando o córrego, a população ainda não atingiu esse patamar de não jogar aqueles detritos, daquele porte. Porque eles estão pensando em sobreviver. Então estão jogando a geladeira ou móvel porque apodreceu e não tem dinheiro para levar, não tem dinheiro para fazer e joga ali que é a terra de ninguém. Então esse patamar também vai ser importante. Quando isso vai ocorrer, evidentemente que vai ocorrer na medida em que a sociedade atingir esses patamares. Vai atingindo patamar? Vai. Vai tendo melhoras ambientais? Com certeza. Isso é uma condição sine qua non. No âmbito europeu, pelo que eu vivenciei nesses últimos meses, esse componente faz parte de qualquer projeto. Vou fazer um projeto de um equipamento, eu vou ampliar uma rua, eu vou fazer um prédio novo, qual é o componente ambiental? Quando que eu estou preservando? O que eu tenho? Qual a minha contribuição para a melhoria ambiental e não ao contrário? Hoje, quem trabalha? Qual que é o meu impacto? Lá eles trabalham? Qual é a minha melhoria? Porque, o impacto, sabe-se que não pode haver. Ou é, se já tem, se é uma região muito impactada, não haverá aquele prédio ali, o prédio tem que existir em outro lugar e a sociedade toda aceita que vai ser em outro lugar. Aqui não, aqui nos estamos ainda no estágio dos impactos. Quanto é que vai impactar? A hora que você vai ver qual a melhoria com a implantação daquele prédio, é o estágio ideal. Aí sim, nós podemos virar o Sena, o Tâmisa etc. Só com relação a virar um Sena ou um Tâmisa, deixar bem claro que são esses dois rios. O Tâmisa é um rio de maré e tem contribuição de estuarina ali, do mar, e ele é um rio cujo volume que passava e passa por Londres é muito maior do que o do Tietê, da ordem de dez vezes o volume de água. E o Sena, como ele esta ali numa região central que vem dos degelos dos montes, como é que é o nome? Belinos, não. Pirineus? Alguma coisa. Então tem o degelo. Lá, então, ele tem a água, renovação de água. Só que quando chegava à região de Paris, que era mais poluída, à medida que foram feitas as contenções e as contribuições de esgoto o Sena ta lindíssimo, belíssimo, com água limpa e tal, e não possui carga poluidora. O problema de São Paulo é que é um rio de baixa vazão na cabeceira, quer dizer, ele nasce a $20 \mathrm{Km}$ de São Paulo e já recebe toda a carga poluidora. Então é um rio que vai demandar demais cuidados. Vai demandar mais coisas, 
aquela região de baixa vazão. Mas o caminho é esse. Tratar dos córregos, dos tributários, preservar os mananciais e também, em cidades da grande São Paulo, que não tratam esgoto. Guarulhos não trata, joga água no Tietê, nos córregos. Então é uma ação não só mais da cidade de São Paulo, mas dos municípios ao lado.

PERGUNTA -- Pensando em sustentabilidade urbana a gente está no caminho?

SR. DOUGLAS BARRETO (IPT) - Diria que sustentabilidade urbana, na vertente Água e esgoto nós estamos no caminho, mas tem muitos outros fatores, certo? Trânsito, emissões, as ilhas de calor, a arborização, parques. São Paulo não tem parque. Não temos aqui nenhum, um desequilíbrio muito grande em zonas extremamente impermeáveis e "concretadas". Vamos assim dizer, com pequenos parques. Pequenas ilhas pequenas. Não temos uma distribuição mais harmoniosa dessas áreas.

PERGUNTA -- Áreas com muito verde e áreas sem nenhum verde.

SR. DOUGLAS BARRETO (IPT) - É, tenho. Você dividir um pelo outro, você fala está legal, mas espera. Aí só tenho um. E não cabe um milhão de pessoas no lbirapuera por exemplo. Se nós pegarmos as árvores que existem lá e dividir pelo entorno vai dar uma árvore para cada habitante. Mas não é isso?

PERGUNTA -- É uma maravilha, certo?

SR. DOUGLAS BARRETO (IPT) - É. Eu tenho que ter uma equação, um pouco mais, por isso que eu estava falando, que com o adensamento, São Paulo não tem mais para onde crescer, não tem como, não é? Ela vai verticalizar um pouco que na minha opinião, necessariamente abrindo mais espaço e criando mais parques.

PERGUNTA -- Um desenho urbano mais...

SR. DOUGLAS BARRETO (IPT) - Um desenho urbano sustentável, certo? Visando a sustentabilidade. Aí entra desenho urbano também. Segundo, Isso é uma questão de 
mobilidade urbana. Tem que ter mais transporte, que poluam menos e em contra partida temos quatro e meio milhões de automóveis poluindo, certo? Temos algumas obras de porte? Tem, tem o Rodoanel. Funciona? Ajuda. Nós temos aí algumas coisas, mas o Rodoanel ele foi imaginado em 1995. Nós estamos em...

PERGUNTA -- 2010.

SR. DOUGLAS BARRETO (IPT) - Então você vê quanto tempo ele está sendo pensado e não está completo? O que ele vai fazer? Ele vai tirar uma carga de trânsito da capital, vai tirar uma carga poluidora associada, ótimo, mas ainda tem problema de mobilidade urbana ali, que são os automóveis e que precisam de mais transporte público. Então do ponto de vista de sustentabilidade urbana, no que diz respeito à água, ao esgoto, estamos bem encaminhados. Nós temos outras questões, de resíduos sólidos, lixo urbano. Há outras medidas para contribuir com a sustentabilidade urbana.

I

PERGUNTA - Então estamos no caminho certo?

SR. DOUGLAS BARRETO (IPT) - Em minha opinião, o caminho é esse. É lento, é isso mesmo. São ações que irão demandar problemas de uso racional e esses programas aqui, eles têm ações imediatas e que têm bons resultados. Mas o grande resultado que é a melhoria da qualidade ambiental, vem a mais em longo prazo.

PERGUNTA -- E tem como pensar em sustentabilidade em uma cidade de 20 milhões assim?

SR. DOUGLAS BARRETO (IPT) - É, pensar assim totalmente sustentável não tem, certo? O desenho urbano de 20 milhões de habitantes, as suas demandas, as suas necessidades, é um impacto irreversível. Se você pensa em fazer aqui um raciocínio simples, se você pensa que você tem que trocar uma janela, a cada 20 anos, se você multiplicar o número de janelas que você tem na cidade de São Paulo, e considerando que a metade é de madeira... Vamos pegar um terço de madeira, outro terço de aço e outro terço de alumínio, falar em sustentabilidade nessa escala é complicado. Então temos que avaliar, que a própria manutenção em si já vai ser impactante. Nós podemos amenizar como produtos que 
preservem que eu não precise trocar a cada 10 anos, ou 20 anos. Nós temos que começar a pensar na cidade sustentável. Cem por cento não têm. Sempre haverá um impacto. Porque você tem o impacto da criação e depois o impacto da manutenção da continuidade das cidades. Que é a demanda por energia, a demanda por água, a demanda por insumos. Quando a gente fala em sustentabilidade, o famoso empate, ele não é impossível, mas para algumas cidades ele vai ser impossível. O que eu quero dizer, São Paulo vai ser difícil empatar, o que entra, sai, então terá que haver reciclagem de diversos níveis, reaproveitamento de várias coisas, otimização de trajetos, um transporte urbano melhor. Quando nós falamos assim, redistribuição de pólos geradores de emprego, isso aí demora anos para se fazer. Como é que você muda um pólo industrial que está na divisa da zona leste para zona oeste. Como é que você deixa equânime? Porque seria o ideal, a pessoa se deslocar menos, a água que chegar a ele viesse de uma fonte mais próxima, ele teria que ter um conjunto de coisas localizadas. Às vezes, ele mora de um lado e trabalha do outro. Precisa de transporte. Á água que vem a ele, às vezes, não vem da zona oeste, vem da zona sul, que está toda interligada.

PERGUNTA -- Trabalhar e morar no mesmo lugar.

SR. DOUGLAS BARRETO (IPT) - Seria o ideal. É o grande baque.

Algumas cidades, no Brasil têm isso: sua locomoção não ultrapassa $5 \mathrm{Km}$, o que é razoável. Você pode ir de ônibus, é factível ir de bicicleta. Cinco quilômetros na escala de deslocamento humano, $5 \mathrm{Km}$ é tranqüilo. Estou falando daqui, da coisa de $15 \mathrm{~km}, 20 \mathrm{~km}$, $25 \mathrm{Km}$, porque São Paulo de ponta a ponta tem $35 \mathrm{~km}$ e $40 \mathrm{~km}$, dependendo da onde ele trabalha, é $25 \mathrm{~km}$, ou outro é $40 \mathrm{~km}$. Só que o caminho para ele percorrer isso, vira $50 \mathrm{~km}$, ou vira $35 \mathrm{~km}$. E o tempo é um deslocamento de $40 \mathrm{Km}$ a $100 \mathrm{~km}$ por hora, que dá uma coisa de $10 \mathrm{Km}$ por hora, certo?

PERGUNTA -- Já muda completamente.

SR. DOUGLAS BARRETO (IPT) - Muda completamente, $10 \mathrm{~km}$ por hora em 40Km.

PERGUNTA -- Muito obrigado. 
APÊNDICE E - Entrevista de Marco Antônio de Oliveira - Sabesp, Coordenador do Projeto Mananciais, por Marcelo Teixeira. (10/06/2010)

PERGUNTA -- O Sr. pode nos falar um pouco do Programa Mananciais?

MARCO ANTÔNIO DE OLIVEIRA(Sabesp): Na verdade trata-se do Programa Vida Nova, antigo Mananciais. O Programa Vida Nova se caracteriza por um convênio firmado entre a Sabesp e PMSP no qual a prefeitura implanta uma nova rede de água e de captação de esgoto que será depois utilizada pelo nosso sistema. Em contrapartida a Sabesp repassará a PMSP cerca de $R \$ 45$ milhões de reais referentes a essa nova estrutura.

PERGUNTA -- A PMSP faz as obras civis e a Sabesp utiliza essa rede posteriormente?

MARCO ANTÔNIO DE OLIVEIRA(Sabesp): Isso mesmo. A PMSP, sob a supervisão da Sabesp, com projetos sob nossa padronização implanta a rede.Cabe a Sabesp a supervisão e o aval a rede instalada. Pela qual serão repassados cerca de $R \$ 35$ milhões pela rede de esgoto e cerca de $R \$ 6$ milhões pela rede de água.

PERGUNTAM -- Quais são as maiores dificuldades desse projeto?

MARCO ANTÔNIO DE OLIVEIRA(Sabesp): Acredito que os assentamentos acabam se mostrando a parte mais delicada do projeto como um todo, por várias razões. A primeira pela descrença dessa população no poder público de um modo geral e em segundo lugar a necessidade de conscientizá-lo a aderir ao sistema pago da Sabesp e deixar de ter uma ligação clandestina. Esse ultimo fator também se mostra bastante complicado uma vez que se mexe diretamente no bolso do morador. Este até então acostumado ao não pagamento da conta de água precisa de todo um trabalho de conscientização. 
PERGUNTA -- Como convencer o usuário a se inserir no sistema da Sabesp?

MARCO ANTÔNIO DE OLIVEIRA(Sabesp): Para estimular a adesão ao sistema há a tarifa social na qual o morador receberá uma conta com valor simbólico durante um ano, podendo se renovar após o término. Também acredito que as pessoas gostam de poder se regularizar, o que não acontecia antes por se tratar de locais ocupados, irregulares, enfim, que não podiam ser abastecidos regularmente devido a legislação vigente.

PERGUNTA -- Como funciona o processo de implantação como um todo?

MARCO ANTÔNIO DE OLIVEIRA(Sabesp): Há um levantamento feito na região e mediante esse diagnóstico são definidos os locais de intervenção. Nesses locais a prefeitura entra com infra-estrutura, rede de água, de esgoto, asfalto, iluminação pública, enfim com uma reurbanização completa da região. A Sabesp acompanha esse processo, e depois interliga essa nova rede coletora de esgoto através de estações elevatórias, à Estação de Tratamento em Barueri, chegando a percorrer no caso da Billings cerca de $60 \mathrm{~km}$ até ter o esgoto tratado.

PERGUNTA -- Esse processo levará a universalização da captação do esgoto e a despoluição da represa?

MARCO ANTÔNIO DE OLIVEIRA(Sabesp): Sim, claro. À medida que se implanta novas redes, e se repara as existentes, nós vamos nos aproximando da meta de universalização. Porém há a necessidade de um monitoramento constante da rede bem como da ocupação irregular no local. Ainda há a inexistência de informação de parte da rede, tanto que parte dos recursos serão transferidos apenas mediante do "as built" a fim de se atualizar os dados para que se facilite a fiscalização e o gerenciamento da rede a fim de evitar mais ligações clandestinas posteriores. 
PERGUNTA -- Esse processo levará a universalização da captação do esgoto e a despoluição da represa?

\section{MARCO ANTÔNIO DE OLIVEIRA(Sabesp):}

PERGUNTA -- Como o Programa se relaciona com as prefeituras vizinhas?

MARCO ANTÔNIO DE OLIVEIRA(Sabesp): Também há essa dificuldade uma vez que a Sabesp não opera todas as cidades vizinhas aos Mananciais. Com algumas, há uma troca muito positiva, como Diadema, por exemplo, cuja rede coletora foi interligada com a rede da Sabesp e teve seus detritos encaminhados a ETE-Barueri, outras, por outro lado, ou não possuem rede de esgoto ou a interferência nos mananciais se deve de maneira muito pequena.

PERGUNTA -- O programa se mostra muito complexo do ponto de vista técnico?

MARCO ANTÔNIO DE OLIVEIRA(Sabesp): Há certa complexidade uma vez que há a necessidade de se elevar através de 6 estações elevatórias todo o esgoto captado até atingir altura o suficiente para continuar seu caminho por declividade até a ETEBarueri. Outro fator bastante complicador se deve ao fato de grande parte da obra ser enterrada, levando a necessidade, em alguns casos, de obras de grande porte. 
APÊNDICE F - Gilmar Massone (Sabesp)- Analista de Sistema de Saneamento/ coordenador do Projeto Córrego Limpo, por Marcelo Teixeira. (19/05/2010)

O SR. GILMAR MASSONE (SABESP) - Gilmar Massone.

PERGUNTA - Cargo na Sabesp?

O SR. GILMAR MASSONE (SABESP) - Analista de Sistemas de Saneamento.

PERGUNTA - A área de vocês integra as demais áreas para o projeto Córrego Limpo?

O SR. GILMAR MASSONE (SABESP) - Isso é a Unidade de Gerenciamento do Projeto (UGP - Córrego Limpo) que cuida da parte da integração das unidades do negócio para a despoluição dos córregos do programa Córrego Limpo dentro do Município de são Paulo.

PERGUNTA - Desde quando que existe este programa da Sabesp?

O SR. GILMAR MASSONE (SABESP) - Esse programa surgiu na unidade de negócio norte na despoluição do Córrego Carandiru, logo em seguida foi feita a despoluição do Córrego Tenente Rocha, o terceiro córrego foi o Ciclovia dentro do Horto Florestal, a partir daí o Governo do Estado de São Paulo adquire o programa. Ele criou o programa na verdade, o programa Córrego Limpo, dentro de outro. O programa Córrego Limpo faz parte de uma coisa maior dentro dos projetos estruturantes. É o que eles chamam de Operação Natureza. Dentro da Operação Natureza é que está o programa Córrego Limpo, Vida Nova, o PURA, o onda limpa. E o Córrego Limpo é um dos programas que está dentro do programa do governo.

PERGUNTA - E vocês estão trabalhando junto com a Prefeitura?

O SR. GILMAR MASSONE (SABESP) - Junto com a Prefeitura, numa parceria que foi iniciada em 2007, com a proposta, na época, de despoluir 42 córregos até 2008. Eles foram 
despoluídos, 28 totalmente, 14 parcialmente e que ainda a gente está correndo atrás desses 14. Além desses teve uma nova meta que é despoluir 58 córregos. Até o segundo semestre de 2010. Até março, desses 58, nós já despoluímos 22, e faltam agora mais 36 . Que a gente pretende entregar parcialmente no segundo semestre de 2010.

PERGUNTA - E porque parcialmente a entrega desses outros?

O SR. GILMAR MASSONE (SABESP) - Na verdade existem alguns córregos que, eles fazem parte do Programa Mananciais, e esses córregos eles são muito complicados porque têm muitas remoções .

Na verdade como tem muita remoção existe o problema de que a Sabesp fez uma previsão de que iria fazer a despoluição contando com o pessoal da SEHAB para fazer as remoções. Só que quando se trata de pessoas a história é muito mais complicada do que você simplesmente fazer obras numa bacia. $E$ ai a remoção demora um pouco mais, você não pode simplesmente tirar as pessoas e colocar em qualquer lugar. Você tem que fazer pesquisa com elas, verificar para onde que elas querem ir, ou, onde que a Prefeitura tem disponibilidade para colocá-las, entende? Tem aí uma alternativa que a Prefeitura está pagando, o aluguel para o pessoal que sai. Mas isso acabou atrasando alguns córregos e a gente acabou despoluindo eles parcialmente, algumas sub-bacias, alguns afluentes desses córregos principais. Por isso que eles foram despoluídos parcialmente.

PERGUNTA - E uma das maiores dificuldades é a questão do assentamento?

O SR. GILMAR MASSONE (SABESP) - É a questão do assentamento. Realmente é o que pega no programa, o que a gente sentiu, e que não tinha percebido isso numa primeira tacada. Quando a gente despoluiu os 42 , a gente achou que era mais tranqüilo a Sabesp. Com o decorrer do projeto a gente percebeu que a história não é bem assim, certo? Você lida com pessoas, a história é um pouco mais complicada.

PERGUNTA - E esses córregos que tiveram 100\% de despoluição, ou no assentamento?

O SR. GILMAR MASSONE (SABESP) - Na verdade nem todos os córregos precisam remover as pessoas. Em alguns sim, em outros não. Mas, nos que houve necessidade de 
fazer a remoção, ou já havia removido antes do inicio do programa, quando o córrego já estava aberto, vamos dizer assim, para a gente poder fazer o assentamento das margens, ou não tinha nenhum tipo de assentamento e a gente pode fazer o assentamento da rede sem problema algum.

PERGUNTA - Nesses casos os problemas maiores eram o esgoto irregular?

O SR. GILMAR MASSONE (SABESP) - O esgoto irregular na verdade é assim, até há uma década, a Sabesp fazia a coleta do esgoto e lançava nos fundos de vales. Por uma questão de Saúde Pública, isso até aprendi na minha pós-graduação, que a primeira questão é você fazer com que o esgoto saia dos pés das pessoas. Por uma questão de Saúde Pública. Num país que está em desenvolvimento você não pode exigir que ele comece um sistema de esgotamento pela estação de tratamento de esgoto. Porque não tem recurso para isso. Então por uma questão de Saúde Pública para que você consiga fazer diminuir o índice de mortalidade infantil, você tem que tirar o esgoto do meio das pessoas e jogar o mais longe possível. E a Sabesp acabou fazendo isso, durante muito tempo, na época eu nem fazia parte da Sabesp ainda, e hoje a gente está resgatando e tirando esses lançamentos e levando ao tratamento de esgoto. Então na verdade o programa Córrego Limpo ele nada mais é do que um complemento do programa de despoluição do Tietê. Lá dentro da Sabesp nós temos um grupo que cuida da despoluição do Tietê e outro grupo que cuida do Córrego Limpo. A despoluição do Tietê, eles começam pelas grandes obras que são as estações de tratamento de esgoto, ampliações dessas estações, implantação dos interceptores ao longo do Tietê, do Pinheiros e de alguns coletores, troncos grandes. E o Córrego Limpo vai, parte dos coletores secundários para interligar nesses coletores que a despoluição do Tietê está executando, e a partir daí essa integração das redes pequenas com as grossas acaba levando o esgoto para estação de tratamento. Então na verdade a disposição do Tietê vem trabalhando de jusante para montante, e o Córrego Limpo vem trabalhando de montante para jusante No momento que eles se encontrarem, a bacia estará totalmente despoluída.

PERGUNTA - Afinal de contas tudo vai parar no Rio Tietê?

O SR. GILMAR MASSONE (SABESP) - Não. 
PERGUNTA - Antes, certo?

O SR. GILMAR MASSONE (SABESP) - Antes sim, antes sim. Hoje grande parte do esgoto já ta indo para estação de tratamento, e o objetivo é fazer com que todo o esgoto vá. E aí existe uma meta da Sabesp que até 2018. A universalização do atendimento.

PERGUNTA - O que não acontece devido às ocupações irregulares.

O SR. GILMAR MASSONE (SABESP) - É. Aí existe a questão também do próprio desenvolvimento do país. E eu costumo dizer o seguinte, que o pessoal que hoje está aqui morando em favela, na verdade é o pessoal que construiu o Estado. Que construiu as cidades. Então o Estado tem que dar um jeito de assentar esse pessoal de uma forma mais humana. Na verdade o pessoal está morando, o pessoal que mora em favela é o pessoal que construiu o estado. Então hoje o pessoal da SEHAB está tentando assentar de uma forma ou de outra, todo esse pessoal que hoje está morando ai nesse fundo de vale. Porque favela normalmente se instala em fundo de vale. Nosso problema é esse. E a gente tem que despoluir o fundo do vale. Então hoje que a gente está tentando fazer o programa, que eu acho legal e que ta evoluindo, não é simplesmente hoje para a despoluição do córrego. Tentar resolver os problemas da bacia como um todo. Fundo de vale, o assentamento as pessoas, o engajamento das pessoas na manutenção, da despoluição nesses fundos de vales. Que é outro "gato" que a gente está percebendo hoje, que a Sabesp, a prefeitura não consegue manter o fundo de vale disponível se essas pessoas não param de jogar lixo, se não cuidarem. A gente fala a Prefeitura, mas de uma forma geral, tem que considerar que aí SEHAB que cuida da parte habitacional, Secretaria do Verde que cuida da parte de jardinagem, plantio de árvores, parques lineares; Então, à medida que a gente vai despoluindo também e têm condições de fazer um parque linear, a gente informa a Prefeitura e fala assim: "Naquele local tem condições de fazer um parque linear." A SEHAB da Prefeitura diz para a Secretaria do Verde e eles vão ao local para verificar se tem ou não condições de fazer um parque linear no local.

PERGUNTA - E aí a população começa a utilizar este espaço de outra forma?

O SR. GILMAR MASSONE (SABESP) - Sem dúvida, começa a usar de outra forma e começa a cuidar desses espaços. Quer dizer, lógico que a gente têm encontrado alguns 
parques lineares já instalados, fundo de vale, tipo recanto dos humildes e que algumas pessoas da população colocaram fogo no parquinho. Depreda tudo, destrói na verdade.

Outro local também que a Prefeitura fez um trabalho muito legal foi no Elisa Maria. Plantou várias, umas centenas de árvores no fundo do vale e a molecada foi lá e arrancou tudo, quebrou todas as armações.

PERGUNTA - O problema educacional?

O SR. GILMAR MASSONE (SABESP) - É muito pesado. Acho que, assim, eu costumo dizer que não é pesado. Acho que ter muita atenção com eles. Uma das coisas que nós percebemos no trabalho de despoluição do Guarapiranga em 1992, e fez-se isso num relatório pela unidade de gerenciamento na época. É que grande parte do trabalho foi perdida lá porque o trabalho de educação ambiental não foi desenvolvido da forma como deveria ter sido. Na verdade foi um aprendizado e hoje a gente tem esse cuidado de estar disparando algumas ações dentro da Sabesp para poder fazer um trabalho de educação ambiental, um engajamento da população que vive entorno do córrego, a começar se envolver mais e procurar preservar e conservar o trabalho que a Sabesp e a prefeitura vem fazendo hoje.

PERGUNTA - E essa história da educação a Secretaria da Educação não está participando ainda desse projeto?

O SR. GILMAR MASSONE (SABESP) - O Estado participa como um todo. O que hoje está sendo feito pela Sabesp, um contrato que foi feito com o Instituto Brasileiro de Pesquisa, é para verificar quais são as necessidades do pessoal que vive entorno ao córrego. Qual que é a sensibilidade que eles têm, e o que desperta o córrego para eles. Então nesse primeiro contato que o CEBRAPE teve, tivemos aí algumas informações do povo que vive em torno dos córregos e em cima dessas necessidades, a gente está tentando o CEBRAPE junto com alguns profissionais da Sabesp, em criar uma rede social dentro dos limites da subbacia, para que essa rede social, ao invés de reuniões entre eles, no início com a Sabesp e CEBRAPE depois ele sozinho, continue fazendo reuniões para manutenção de fundos de vale. Ou até mesmo disparar a Sabesp ou a Prefeitura quando tiver algum problema dentro da bacia que seja de competência da esfera governamental, para poder fazer a manutenção do sistema. 
PERGUNTA - Quer dizer, são ações de longo prazo,?

O SR. GILMAR MASSONE (SABESP) - Não é longo prazo. Eu costumo dizer que é eterna.Como um filho que nasce e você tem que cuidar dele para sempre. Não tem como.

Uma vez que o córrego está despoluído você é obrigado a mantê-lo despoluído. Para mantê-lo despoluído você tem que utilizar as forças do Governo e outras forças, que é as do pessoal que mora no entorno. Sem eles, sem a população não existe como manter um córrego despoluído.

PERGUNTA - Você acha que esta é uma das partes mais difíceis do Projeto?

O SR. GILMAR MASSONE (SABESP) - É a mais difícil e a mais importante. Engajamento. Só que isso, eu acho que é demorado. Eu, Gilmar, acho que, particularmente, é demorado. Porque você desperta nas pessoas a importância de uma coisa que eles nem reconheciam como sendo uma área de lazer. Como área de lazer, área de contemplação entendeu? Que na verdade córrego hoje é esgoto a céu aberto e o que as pessoas querem mesmo é se ver livre deles. Querem canalizar. A maioria quer canalizar os córregos.

PERGUNTA - Tampar?

O SR. GILMAR MASSONE (SABESP) - Tampar. Eles não imaginam que um córrego pode estar despoluído, possa ter peixe, possa ter aves, garças, como a gente tem visto em alguns córregos por aí, certo?

PERGUNTA - Até mesmo no Tietê que já voltou, certo?

O SR. GILMAR MASSONE (SABESP) - Sim, é. O Tietê ele está melhorando aos poucos. $\mathrm{Na}$ verdade ele é o reflexo daquilo que a gente está fazendo nos afluentes. À medida que todos os afluentes do Tietê chegarem despoluídos até ele, ele será a soma de todos os afluentes. Aí sim ele vai estar despoluído. 
PERGUNTA - Mas nos córregos onde houve intervenção já têm uma visibilidade muito boa?

O SR. GILMAR MASSONE (SABESP) - Sem dúvida. Temos alguns córregos que chegam ao Tietê cristalinos. Chega com DBO no nível de classe dois, DBO igual a seis miligramas por litro. Que a DBO é a demanda bioquímica de oxigênio. Então a gente tem conseguido. Alguns córregos chegam com a DBO muito baixa ao Tietê com condições de vida, inclusive com peixinho ou alguma coisa assim.

PERGUNTA - E alguns eventos da Sabesp têm sido responsáveis até como vitrine nesse projeto?

O SR. GILMAR MASSONE (SABESP) - Sem dúvida. Na verdade a Sabesp está fazendo a lição de casa, mas a gente está tentando mostrar porque a população precisa começar a acreditar no programa. Se a população não acreditar no programa, o programa não vai dar certo.

PERGUNTA - E a receptividade tem sido muito boa?

O SR. GILMAR MASSONE (SABESP) - Muito boa, porque o efeito do córrego despoluído em cima da população é imediato.

PERGUNTA - É imediato?

O SR. GILMAR MASSONE (SABESP) - É imediato. Um córrego poluído, Um córrego que ficou poluído durante 30, 40 anos, numa temporada de chuva ele fica cristalino, o fundo fica limpo, já surge vida. É uma coisa impressionante.

PERGUNTA - Agora outro problema são os córregos canalizados? 
O SR. GILMAR MASSONE (SABESP) - Bom, existe ai em alguns países em que os córregos foram canalizados, e que hoje eles estão sendo renaturalizados. A renaturalização é um processo diferente da despoluição. A despoluição você tira toda a demanda, você tira todos os poluentes da água. Aí faz com que ele fique em condições de ter vida. A renaturalização passa a deixar o mais próximo possível dos córregos, daquilo que ele era na origem. A primeira coisa é arrancar todo o concreto dele, mesmo ele estando a céu aberto. Só que para que você consiga fazer isso você precisa ter uma população em que esteja, educada e pronta para tomar conta do córrego. Porque na verdade hoje a "concretagem", eu costumo falar isso, a "concretagem" dos córregos de céu aberto, ela é necessária por questão de limpeza. Você não consegue manter um Córrego Limpo se você não o tiver "concretado", porque toda a sujeira acaba parando às margens, então você teria que fazer a limpeza em toda a margem, sendo que você não precisava fazer essa limpeza se você tivesse um povo que não jogue lixo na rua, não jogue latinha pela janela, não jogue saco de lixo no fundo do vale. É curioso inclusive que você vê algumas pessoas com cachorro, passeando com cachorro e que coloca as fezes do cachorro dentro do saco de lixo, amarra o saco de lixo e joga no córrego. Então o córrego a impressão que dá é que não despertou nas pessoas ainda que não seja o local de jogar lixo.

PERGUNTA - E o senhor acredita que em longo prazo seria a renaturalização numa outra etapa do projeto?

O SR. GILMAR MASSONE (SABESP) - Eu acredito. Eu não tenho ao menos dúvida disso, isso está acontecendo na Alemanha, está acontecendo na França. Estive em um encontro internacional em que esteve o pessoal da França, da Inglaterra, da Alemanha, e eles, hoje, estão numa fase de re-naturalização. O lixo, o pessoal joga no lixo. As pessoas solicitam a re-naturalização do córrego já sabendo que eles serão os responsáveis por manter aquele Córrego Limpo, despoluído, em condições de conservação, condições de vida às margens dele.

PERGUNTA - E como tem ficado a questão das enchentes, nesses córregos já trabalhados?

O SR. GILMAR MASSONE (SABESP) - A enchente é um trabalho a parte. Não tem nada a ver com a despoluição. A enchente é um trabalho de macro-drenagem do Município. 
A questão da macro-drenagem é um trabalho que tem que ser feito em cima dos dados da precipitação pluviométrica. Em cima dessa precipitação você faz os cálculos dos canais, das galerias. O que aconteceu nesse mês de janeiro é que nunca houve um período de chuva como esse. E quando houve, há 75 anos, a realidade da cidade era outra. A impermeabilização da cidade era outra.

O que acontece? À época, há 70 anos, quando teve esse tipo de chuva, não houve alagamento porque houve infiltração da chuva no solo.

Hoje não, hoje a chuva não infiltra, ela escoa. Quanto mais área impermeabilizada, mais rápido ela escoa para o ponto mais baixo e no ponto mais baixo não tem como fazer a absorção dessa água. Então alaga. Isso é natural. É natural esse alagamento.

Agora quais são as saídas hoje? São de procurar alternativas. Ou se faz a reservação dessa água através dos piscinões, ou se faz com que essa água escoe mais rápido para o Tietê e faz com que o Tietê escoe mais rápido.

PERGUNTA - Mas uma coisa, uma coisa não está ligada a outra. O projeto do Córrego Limpo não está ligado à enchente?

O SR. GILMAR MASSONE (SABESP) - Não está. As pessoas acabam ligando porque na hora que mexe ali tem -se a impressão que se resolverá todos os problemas.

PERGUNTA - Como são medidos os parâmetros nós locais já trabalhados?

O SR. GILMAR MASSONE (SABESP) - É interessante. Alguns córregos que existem peixe, por exemplo.Já está cheio de peixes, as garças vão lá comer e tudo mais. Quando ele enche a lâmina dele sobe de 2 centímetros para um metro. 50 vezes o volume dele normal. A primeira vista a gente acha que toda a vida animal foi embora. Só que o peixe... Acontece o seguinte: à medida que o fluxo d'água começa a tomar maior velocidade, eles se escondem nas tocas. E depois que a chuva passa, eles saem das tocas. A partir daí, continuam ali. Então a primeira impressão que dá é que vão embora, mas não vão. Quando você tem um solo no fundo do rio, em que a terra, você tem consciência da preservação da vida que se desenvolve ali. Que é no caso da re-naturalização. Você vai deixar tudo natural. Quando você tem "concretado", todo o tipo de vida que se desenvolve acaba indo embora. Aí toda essa biota começa, de novo, do ponto zero. Agora a questão da enchente não tem 
absolutamente nada a ver. E uma questão ai de macro drenagem do município, existe um grupo na prefeitura que foi definido pelo prefeito para que tratasse disso. Hoje no estado de São Paulo são 255 pontos de alagamento, 51 pontos crônicos e desses 51 pontos crônicos, já está sendo feito um trabalho, para se resolver o problema. Para que, em chuvas iguais a essa, não aconteça novamente. O que se prevê é que essas chuvas que foi cíclica durante muito tempo ela possa, a partir de agora, ser algo mais constante. Devido ao problema do aquecimento global, essa coisa toda, existe essa preocupação hoje. Então eles tão querendo uma resposta muito rápida, mas que sabem que não podem, porque tem que contratar projetos, primeiro fazer um trabalho de diagnóstico, depois de contratar o projeto, vem a obra. Isso demora certo tempo. Então eu acredito que ainda teremos problemas com enchente. Mas que o pessoal ta correndo atrás, e acredito que eles vão resolver.

PERGUNTA - Então nesses córregos trabalhados ocorreu alguma melhora dessa situação de enchente, colaborado para uma solução?

O SR. GILMAR MASSONE (SABESP) - É. Na verdade todos os córregos pela lei de 1934, deveriam ter uma faixa de 15 metros de cada lado.

PERGUNTA - De impermeabilidade.

O SR. GILMAR MASSONE (SABESP) - É o local da várzea do córrego. Só que isso não foi respeitado em todos os bairros hoje. As pessoas não têm noção de quanto de córrego existe.

PERGUNTA - Seria mais ou menos quanto?

O SR. GILMAR MASSONE (SABESP) - É uma coisa assustadora. Por exemplo, na bacia do Mandaqui, que tem um córrego principal que o Engenheiro Caetano Alves que tem 6,5 $\mathrm{Km}$ de comprimento, tenho um plano de $75 \mathrm{~km}$ de afluentes. Eu tenho 33 afluentes no córrego do Mandaqui. Cada afluente desse deveria ser respeitado no seu fundo de vale. Não digo uma margem de 15 metros, mas pelo menos uma margem satisfatória, para que você conseguisse fazer um assentamento de rede, que se conseguisse fazer um trabalho nesse fundo de vale. Mas as pessoas simplesmente lançam o loteamento, criaram os lotes 
dentro dos córregos como se fossem realizar uma terraplanagem. Acharam que canalizando esse córrego iria resolver esse problema. E não resolveu porque hoje esses córregos são nosso maior problema, na despoluição. O pessoal lança esgoto nesses fundos de vales e, às vezes, coberto. A gente tem que descobrir quem que está fazendo isso. Aí tem que ser por meio de "televisionamento" . por teste de corantes. É um trabalho bastante cansativo.

PERGUNTA - "Televisionamento"?

O SR. GILMAR MASSONE (SABESP) - "Televisionamento", filmagem mesmo. Coloca a câmera La dentro do poço de visita com um controle remoto com carrinho. O carrinho vai verificando quem está fazendo o lançamento.

PERGUNTA - E a Sabesp multa?

O SR. GILMAR MASSONE (SABESP) - A Sabesp não, a Prefeitura. A Sabesp comunica a Prefeitura e é ela que tem o poder da multa, comunica o morador que tem que regularizar a ligação dele.

PERGUNTA - E os córregos que elas acabam sendo intermunicipais, acabam nascendo em outras localidades?

O SR. GILMAR MASSONE (SABESP) - Hoje a Sabesp apesar de ter um acordo com a Prefeitura de passar córregos do Município também está trabalhando em outros Municípios. Então isso não impede que a gente faça. Tem o córrego Continental que é o córrego entre Osasco e São Paulo, que divide, que está sendo despoluído e a Prefeitura de Osasco tem cumprido a parte dela e a Prefeitura de São Paulo faz na outra margem. Cada Prefeitura cuida da sua margem.

PERGUNTA - Então esses convênios agora estão sendo expandidos?

O SR. GILMAR MASSONE (SABESP) - Estão sendo expandidos. A Sabesp tem procurado manter e isso será expandido mais ainda com todos os Municípios em que a Sabesp opera. 
PERGUNTA - Então a dificuldade ainda continua sendo naqueles Municípios vizinhos que não são operados pela Sabesp?

O SR. GILMAR MASSONE (SABESP) - Sim. Não digo nem dificuldade, porque hoje existe na maioria dos Municípios o programa Córrego Limpo. Hoje está amplamente divulgado e os Municípios que não estão sendo operados pela Sabesp, também estão desenvolvendo programas paralelos. Não é Córrego Limpo, mas é Margem Limpa, por exemplo. Deram outros nomes, mas na verdade, no fundo é o mesmo programa.

PERGUNTA - Gerou uma cópia.

O SR. GILMAR MASSONE (SABESP) - Exatamente, muito legal isso. Isso foi muito legal.

PERGUNTA - Estão surgindo "franquias" ?

O SR. GILMAR MASSONE (SABESP) - Sem dúvida, não só em São Paulo como inclusive em outros estados.

PERGUNTA - E há uma integração fortíssima então com o projeto de Vida Nova, os Mananciais e com o Projeto Tietê?

O SR. GILMAR MASSONE (SABESP) - O programa dos Mananciais, eu acho extremamente importante, porque primeiro ele cuida da bacia como um todo. Não cuida simplesmente de um córrego, ele cuida de todos os córregos, de todos os fundos de vale e de todas as favelas dentro da bacia. Então o núcleo de Mananciais. Eles cuidam da bacia que é como se deveria ser tratado o programa Córrego Limpo, como um todo também. $E$ acredito que hoje o caminho está sendo esse, a gente está caminhando para isso, para fazer o programa Córrego Limpo, não apenas de um afluente e sempre de uma bacia completa, com todos os seus problemas.

O problema dos córregos é problema habitacional, problema de desenvolvimento de uma rede das lideranças dentro da bacia, para que a gente mantenha os córregos despoluídos. 
Para você manter uma a bacia despoluída, você tem que despoluir todos os afluentes. E todas as pessoas envolvidas dentro da bacia têm que estar cientes de que têm que cuidar.

PERGUNTA - E a poluição difusa nessas áreas é muito alta também?

O SR. GILMAR MASSONE (SABESP) - A poluição difusa hoje é medida, eu fiz alguns trabalhos, em torno de $30 \%$. Só que a poluição difusa não depende também só das pessoas, existe outras coisas de legislação que acho que é um problema que deve ser cuidado através de outras esferas, que é pneu de carro, a borracha que desgasta. Outra coisa que polui e muito, e acho isso impressionante, isso a gente percebe, é a pastilha dos carros, que a hora que chove você vê aquele caldo preto que escoa pelo meio fio. Aquele caldo preto é pastilha, mais pastilha do que pneu. $\mathrm{Na}$ verdade tudo isso ocorre. Isso compromete bastante o desenvolvimento de vida nos córregos. E a gente costuma dizer que córrego em área urbana não é como córrego em área rural. No da área urbana têm essas coisas de que a gente tem que tomar muito mais cuidado do que córrego em área rural.

PERGUNTA - Uma das coisas então é a meta que se está trabalhando para 2018. Muitos programas da Sabesp estão pensando nessa data, mas a questão do assentamento fica até um pouco difícil?

O SR. GILMAR MASSONE (SABESP) - Fica difícil porque pelo planejamento da Prefeitura a impressão é que eles talvez não consigam concluir isso até 2018. E aí, talvez, o programa da Sabesp fique um pouco comprometido porque vai depender de remoção da Prefeitura.

O que a gente vai tentar fazer, eu acho que aí está a solução, é do Governo do Estado e do Governo do Município tentar acertar a melhor forma de trabalhar com isso. Porque o problema todo também é a questão de projeto. Como que você consegue tirar 50 mil pessoas, 100 mil pessoas que vivem no fundo de vale? Como que você construiria casas para elas? Como que você desenvolveria projetos? Você tem área para poder construir esses imóveis? Você tem projetos para esses imóveis?

São coisas que o pessoal tem que buscar a partir de já. A impressão que eu tenho é que hoje o problema já não é mais dinheiro. O problema é projeto executável. Um bom projeto em que você possa desenvolver e depois você consegue implantá-lo. 
PERGUNTA - E nesses casos de assentamento, de saneamento também não é mais político?

O SR. GILMAR MASSONE (SABESP) - Hoje não. Hoje a política de Governo Municipal e Governo do Estado parece que é super tranqüila.

PERGUNTA - Além do mais, não tem mais como a Prefeitura fugir dessa questão?

O SR. GILMAR MASSONE (SABESP) - É, hoje não dá mais para fugir, até por ser uma questão ambiental, que é a questão da Sabesp e a outra é a questão que é habitacional da Prefeitura. Como que você dá um jeito nisso? A população cobra isso. Então tem que ser dado um jeito. Não tem como. Não tem como fugir. Hoje não depende mais do Governo de Estado nem da Prefeitura, hoje a população está bastante informada e exige seus direitos. As pessoas hoje não se negam mais a pagar uma prestação de uma casa, até porque hoje a prestação de uma casa não é como há 40 anos em que era uma coisa absurda. Hoje existem condições de pagar.

PERGUNTA - É mais acessível?

O SR. GILMAR MASSONE (SABESP) - Muito mais acessível.

PERGUNTA - E o fato do Córrego Limpo está trabalhando numa coisa mais visível também colabora para isso?

O SR. GILMAR MASSONE (SABESP) - Sem dúvida. Até por que num assentamento em fundo de vale antigamente as pessoas imaginavam que iam construir uma casa perto do esgoto. Hoje não. Hoje é perto de um córrego, perto de um rio, em que tem peixinho, em que tem tudo mais. É bastante interessante, porque hoje a gente percebe que os córregos que são melhores cuidados, em que a população se envolve mas com eles são os córregos em que as casas estão de frente para esses córregos. Porque normalmente a população constrói as casas de costas para o córrego. Porque ali corre esgoto. Mais nos córregos em 
que corria esgoto e as casa eram obrigadas a serem construídas para frente desse córrego, hoje eles cuidam muito mais do córrego do que o pessoal que tem os córregos perto das casas. E hoje é interessante, por que, normalmente hoje ao longo desses córregos a prefeitura tem construído pistas de correr, alguns parquinhos com uns brinquedos, algumas mesinhas pros aposentados jogarem damas, xadrez, essas coisas. Então é muito legal isso que a Prefeitura está fazendo também.

PERGUNTA - Acaba se tornando uma vitrina eleitoral.

O SR. GILMAR MASSONE (SABESP) - Exatamente. Uma vitrina eleitoral. Acho até que hoje, num primeiro momento, sim. Mas acho que isso depois vira rotina. Por que a Prefeitura também coloca hoje parquinhos, coloca essas paracinhas com banquinhos, com mesinhas para jogos de xadrez, damas e dominó? Porque é uma forma também dessas pessoas não invadirem esses espaços.

PERGUNTA - Começam a usar, certo?

O SR. GILMAR MASSONE (SABESP) - Isso. Aí esse uso passa a ser um uso comum de todos que vivem na comunidade. E não um oportunista que vai lá e constrói uma casinha ou um barraco. O objetivo é sempre fazer com que esses espaços sejam para todo mundo.

PERGUNTA - Gilmar, você tinha comentado sobre a questão da Alemanha, da França, enfim, da renaturalização desses países. A questão tecnológica, o Brasil está nessa posição tecnológica na questão de saneamento, na questão dos córregos, como que a Sabesp está nesse posicionamento?

O SR. GILMAR MASSONE (SABESP) - A tecnologia hoje que a Sabesp utiliza para fazer suas obras é que assim, no projeto Tietê hoje, a tecnologia é americana. A tecnologia alemã, as máquinas fazendo os interceptores que são método não destrutivo. São máquinas no estilo daquelas que constroem o Metrô, 12 metros de profundidade, diâmetro de 2 metros e meio, diâmetro de 3 metros. Tem aí a tecnologia que hoje nós utilizamos. Aqui está super avançada. Tem uma metodologia no caso que a gente tem utilizado muito no 
programa Córrego Limpo, um método novo não destrutivo de tubo puxado. Ele é mais ou menos como aquelas ligações que o pessoal faz da Comgás...

PERGUNTA - Sei, o "tatuzinho".

O SR. GILMAR MASSONE (SABESP) - Isso "tatuzinho". Na verdade a gente também costuma usar a mesma metodologia, com diâmetro de 300, 400 milímetros, com profundidades de 7, 8 ou 9 metros, depende da necessidade. Acima de 4 metros, a gente já está utilizando essa metodologia, que é muito boa, prática e rápida. Funcional.

PERGUNTA - Teleguiado?

O SR. GILMAR MASSONE (SABESP) - Isso, exatamente! É tudo calculado, diâmetro do tubo, tudo certinho. Você sabe o ponto de partida o ponto de chegada. É fantástico.

PERGUNTA - A gente ainda está importando tecnologia ou a gente já passou a desenvolver tecnologia?

O SR. GILMAR MASSONE (SABESP) - Não essas máquinas são importadas, eu acredito, não tenho certeza, mas acredito que as máquinas não são produzidas aqui.

PERGUNTA - E a Sabesp nesse sentido também está...

O SR. GILMAR MASSONE (SABESP) - Na Sabesp esse trabalho é terceirizado, contratado as empresas de engenharia. Ai é feito a concorrência, acho, que é feito o pregão que o pessoal faz e aí quem der o menor preço...

PERGUNTA - Vai poder mexer na questão de saneamento nos córregos, na questão da despoluição desses córregos. A tecnologia que a Sabesp utiliza é de ponta? 
O SR. GILMAR MASSONE (SABESP) - É de ponta. O material utilizado hoje na execução das redes, tubos plásticos é especial para esgoto de cor marrom. Os poços de inspeções eles são pré-fabricados, anéis de concreto. Então são obras rápidas e práticas.

PERGUNTA - A recuperação de um córrego está demorando mais ou menos quanto tempo?

O SR. GILMAR MASSONE (SABESP) - Depende do tamanho do córrego. A gente costuma dizer do grau de dificuldade. Que na verdade quando você recupera um córrego, às vezes, pode ser um córrego pequeno, só que se a bacia for muito grande você tem que atuar em toda a bacia com tratamento e em todos os afluentes. Às vezes para você despoluir um córrego no Parque da Juventude, que está despoluindo o córrego do Carandiru, nós tivemos que atuar em 19 sub-bacias, 19 afluentes, então é um trabalho muito grande. Não tem um prazo fixo. Quando você trabalha num afluente, você pode trabalhar e desenvolver um trabalho em seis meses, em três meses se for pouca intervenção. Mas se for um, dependendo da bacia você fica de dois a três anos. Não tem como executar em menor tempo, porque você tem que fazer o diagnóstico, que abrir todos os PV para ver se todos estão funcionando, se todas as redes estão sendo operadas corretamente, se não tem nenhum vazamento nessa rede, em galeria de águas pluviais. Que na verdade as galerias são córregos, são os afluentes que lançam o corpo de água principal, que lançam o córrego principal. Você tem que ir abrindo toda a rede coletora de esgoto e ao mesmo tempo ao lado dessas redes coletoras abrir as galerias de águas pluviais, para verificar a qualidade da água pluvial que escorre naquele afluente. Na medida em que você descobre um impacto de esgoto você tenta descobrir também sua origem. E esse trabalho demora em torno de um ano mais ou menos, de seis meses a um ano.

PERGUNTA - E assim, ultimamente apareceu na mídia a questão do lbirapuera, o lago do Ibirapuera, o córrego do Sapateiro, o que anda acontecendo?

O SR. GILMAR MASSONE (SABESP) - Não é que anda acontecendo. É que assim, a partir do momento que você vai fazer a despoluição do córrego, você tem que constantemente verificar se ele continua despoluído ou não. Então existem monitoramentos dos córregos que estão em despoluição, que a gente já despoluiu e que se encontra em 
manutenção. A gente faz a coleta mensalmente, faz a análise dessa coleta e verifica qual o grau de poluição.

PERGUNTA - Inclusive tem até uma estação ali no Parque do Ibirapuera...

O SR. GILMAR MASSONE (SABESP) - Uma estação de flotação. E no caso do Ibirapuera, já aconteceu algumas vezes. Lembro de um trabalho que eu executei lá em 1985. Foi um problema de poluição que veio de uma favela que estava sendo instalada na cabeceira da bacia, perto da Domingos de Moraes. Ficou conhecida como favela do INSS. Era a favela no INSS. O terreno ali era do INSS. E naquela época, nós fomos lá, fizemos as redes dentro da favela, fizemos a captação de esgoto, só que o esgoto estava sendo lançado na galeria, e aquela galeria é um dos afluentes do lago do Ibirapuera. Então todo o esgoto estava indo para o lago. Fizemos a canalização da rede de esgoto, lançamos em uma rede oficial, que é para tratamento. Só que de vez em quando surgem outros lançamentos, alguma rede que rompe por baixo da terra, e que aí infiltra e acaba caindo na galeria e acaba poluindo o lago. Qual foi uma das alternativas na época? Bom, para que a gente consiga fazer, minimizar o impacto antes de chegar ao lago, vamos fazer uma estação de flutuação. O que é uma estação de flutuação? Você pega o rio que vai chegar ao lago, e com gradeamento você retem a parte grossa que ai no caso seria a poluição difusa que é um lixo, essas coisas todas mais grossas mesmo. Você faz a retenção dessa parte, a água que chega você faz um pré-tratamento químico dessa água, ai você joga ela, tem uma caixa de retenção de areia ai você joga ela no lago. Então pré-tratamento antes de chegar ao lago. Quando a chega essa água, quando chega à estação de flutuação, é feito uma análise dessa água que chega e é feita uma análise depois da água que sai. À medida que a água chega a flutuação , aumenta a quantidade de poluentes, aí o pessoal sabe que tem que fazer alguma coisa na bacia porque está acontecendo algum foco de poluição, que tem que ser descoberto. Começa um trabalho tudo de novo. É um filho que nasce e você tem que cuidar para sempre.

PERGUNTA - Fica monitorando o tempo todo?

O SR. GILMAR MASSONE (SABESP) - Exatamente, não tem como. É um trabalho...

PERGUNTA - Que quando a pessoa fala até 2018 na verdade só o meio do processo. 
O SR. GILMAR MASSONE (SABESP) - É, assim, é você tentar fazer com que eles fiquem despoluídos. Mas a manutenção é para sempre. Não tem como. Então o sistema uma hora, uma hora o sistema dá problema. O sistema de água. De vez em quando não estoura uma rede ai numa adutora. Gás de vez em quando também não acontece vazamento. Com o esgoto é a mesma coisa. E tem que correr atrás e tem que fazer o concerto.

PERGUNTA - E dá para ser otimista numa região como São Paulo?

O SR. GILMAR MASSONE (SABESP) - Olha, eu sou otimista, eu trabalho há 34 anos na Sabesp e há 34 anos com esgoto. Eu acho que agora, final de carreira, faltando seis meses para me aposentar, acho que estou otimista. Estou otimista. Tanto que o projeto Tietê começou em 1992, um trabalho muito legal, que vem ainda. É um trabalho muito grande, as pessoas não percebem porque está em baixo da terra e o efeito ainda não da para sentir. Mas o programa Córrego Limpo está aí para isso, para fazer as pessoas perceberem que tem jeito, que tem como fazer.

PERGUNTA - E isso eu diria assim, você completou 34 anos de Sabesp e nesses últimos tempos você ficou mais otimista?

O SR. GILMAR MASSONE (SABESP) - Sim.

PERGUNTA - O que mudou na Sabesp, para voltar esse otimismo ou não?

O SR. GILMAR MASSONE (SABESP) - Não é que mudou na Sabesp, na verdade isso é uma cultura mundial. Todo o país que é subdesenvolvido não tem rede de esgoto, não tem estação de tratamento, não tem nada. Mas quem vive na pobreza não tem dinheiro para aplicar em saneamento básico. Na medida em que começa a se desenvolver, ele começa a se preocupar com saneamento básico por que ele sabe que através do saneamento básico você diminui a quantidade do índice de mortalidade infantil, doenças infecciosas e tudo mais. E hoje o Brasil está numa fase de desenvolvimento e economicamente, a gente pode dizer que o saneamento realmente será universalizado. Especialmente em São Paulo, que é um estado desenvolvido e que as pessoas cobram mais. Mais estou percebendo que isso está se espalhando para todos os outros estados. A gente conta hoje com a rede da 
Internet, a gente percebe que está todo mundo fazendo alguma coisa, existe disponibilidade de dinheiro no Governo Federal, só que precisa de projetos para retirar esse dinheiro. $O$ Governo Federal também não disponibiliza dinheiro assim. Mas, com um projeto, você pode através de outros órgãos também ligados ao Governo do Estado conseguir dinheiro para fazer um desenvolvimento para o Sistema de Saneamento.

PERGUNTA - Houve duas questões, uma dessas era que na questão política que obra enterrada não dava voto. Isso já mudou?

O SR. GILMAR MASSONE (SABESP) - Mudou. Hoje a questão é ambiental.

PERGUNTA - É ambiental, certo?

O SR. GILMAR MASSONE (SABESP) - É ambiental.

PERGUNTA - Se não tiver a preocupação ambiental não...

O SR. GILMAR MASSONE (SABESP) - Hoje o pessoal está mais atrás do ambiental do que da obra enterrada. Hoje eles sabem que obra enterrada é obra que vai fazer com que ele despolua o rio. E isso...

PERGUNTA - E temos um BID monitorando? Outros órgãos internacionais?

O SR. GILMAR MASSONE (SABESP) - É, e até para você conseguir algum, vamos dizer assim, algum empréstimo externo de fora do país, você tem que mostrar o que você esta fazendo para sustentabilidade.

PERGUNTA - compensações? 
O SR. GILMAR MASSONE (SABESP) - Isso compensações ambientais e tudo mais. Então hoje o negócio é legal. Hoje está mudando.

PERGUNTA - E outro ponto, assim, a impressão que eu tenho é que houve uma mudança de gerenciamento, de gestão na Sabesp Isso aconteceu, não aconteceu?

O SR. GILMAR MASSONE (SABESP) - Hoje a Sabesp está com mais propostas ambientais, ela é uma firma mais ambiental do que uma de engenharia pura e simplesmente. Apesar de que hoje a engenharia também esta muito preocupada com essa questão ambiental. Todas as áreas estão preocupadas, certo? Mas o foco, por exemplo, que para a Sabesp era só engenharia, hoje não mais. Hoje o foco dela é engenharia, mas estando voltada para questão do meio ambiente.

PERGUNTA - Tanto é que agora não se fala mais numa empresa de saneamento, hoje se fala uma empresa do meio ambiente.

O SR. GILMAR MASSONE (SABESP) - Exatamente, nas soluções ambientais. Então hoje ela corre atrás de tentar arrumar a casa, tentar fazer com que todo o sistema de saneamento hoje que ela é responsável funcione dentro de todos os parâmetros ambientais dentro da melhor maneira possível.

PERGUNTA - Gilmar, muito obrigado.

O SR. GILMAR MASSONE (SABESP) - Tudo bem, nós estamos à disposição.

PERGUNTA - Obrigado.

Anexo A - Resumo dos resultados do Projeto Tietê 


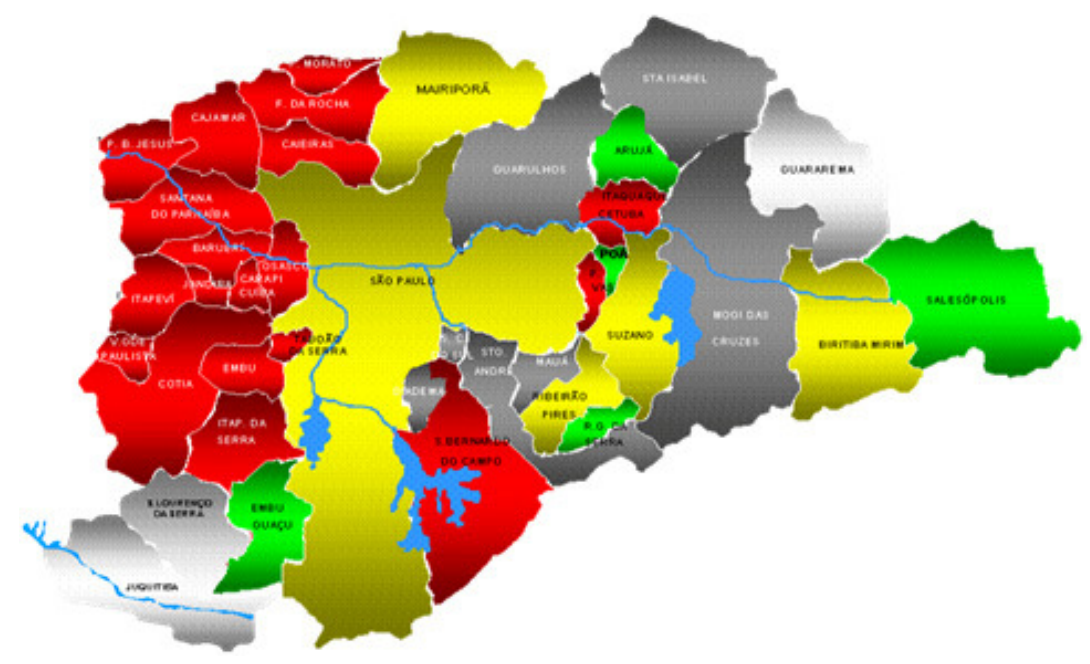

$$
\begin{gathered}
\mathrm{RMSP}-2007 \\
59 \%
\end{gathered}
$$

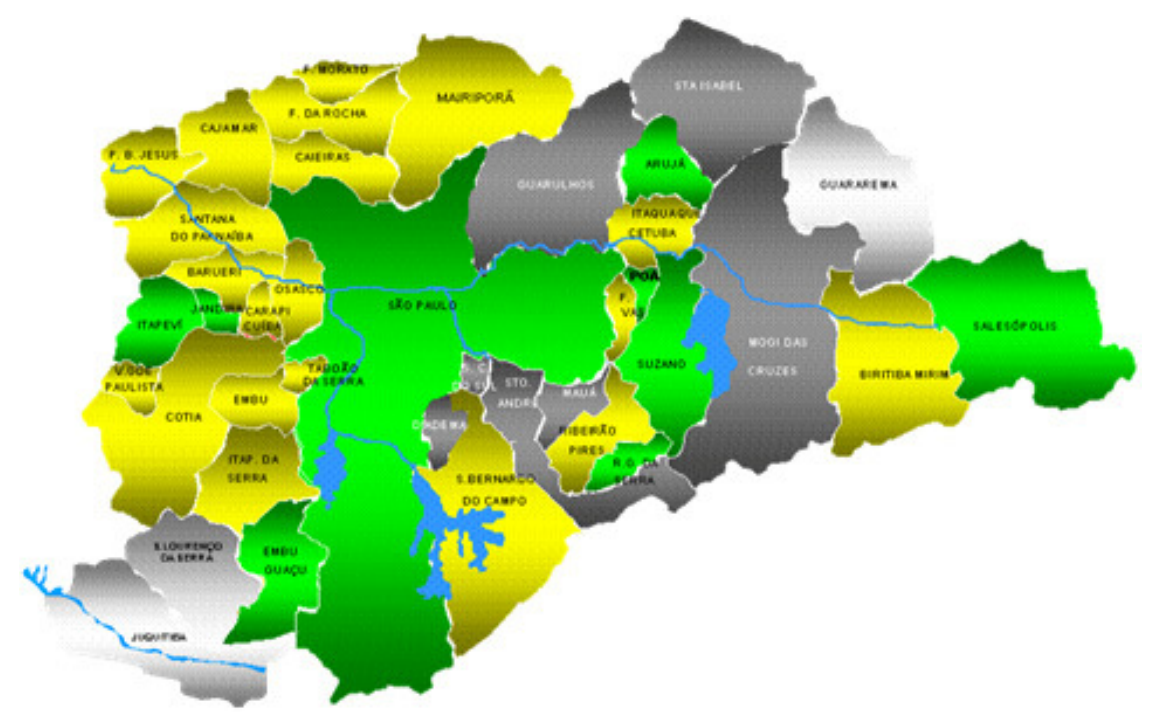

$$
\begin{gathered}
\text { RMSP }-2014 \\
79 \%
\end{gathered}
$$

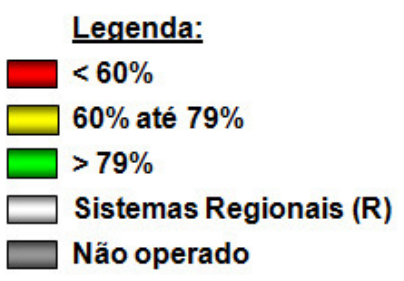

Figura 5 - Projeto Tietê - $3^{\text {a }}$ etapa - Evolução dos índices de tratamento de esgotos Fonte: Sabesp 


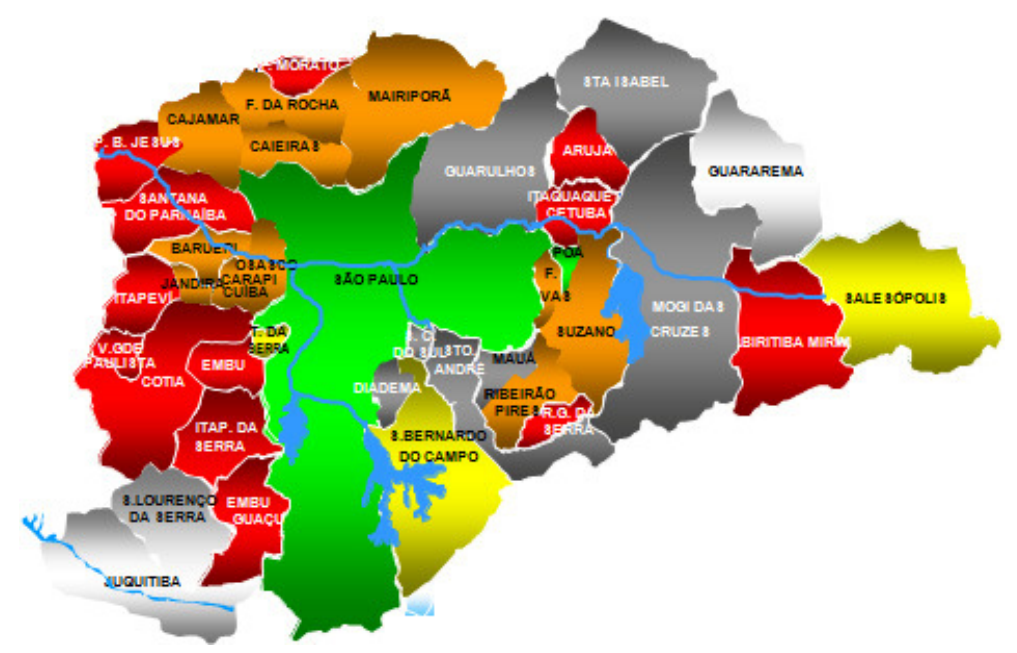

$$
\begin{gathered}
\text { RMSP }-2007 \\
83 \%
\end{gathered}
$$

POPULAÇÃO ATENDIDA - 12,8 milhões de habitantes

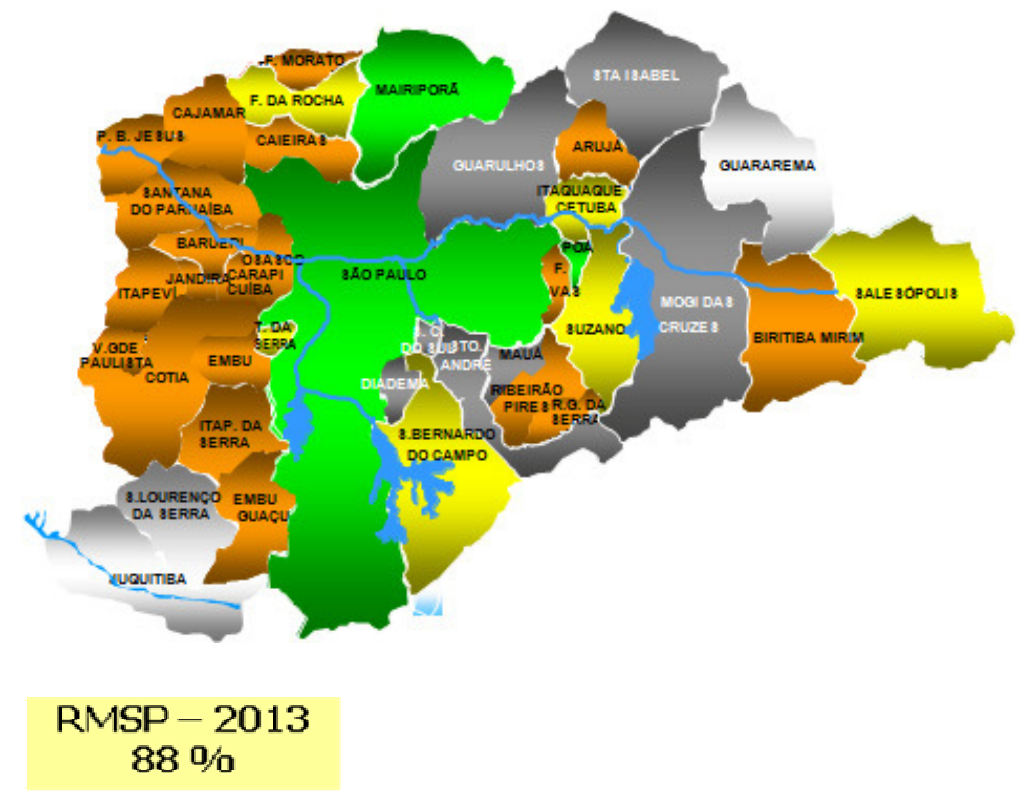

POPULAÇÃO ATENDIDA - 14,3 milhões de habitantes

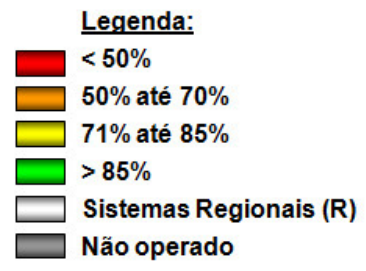

Figura 6 - Projeto Tietê - $3^{\underline{a}}$ etapa - Evolução dos índices de coleta de esgotos Fonte: Sabesp 


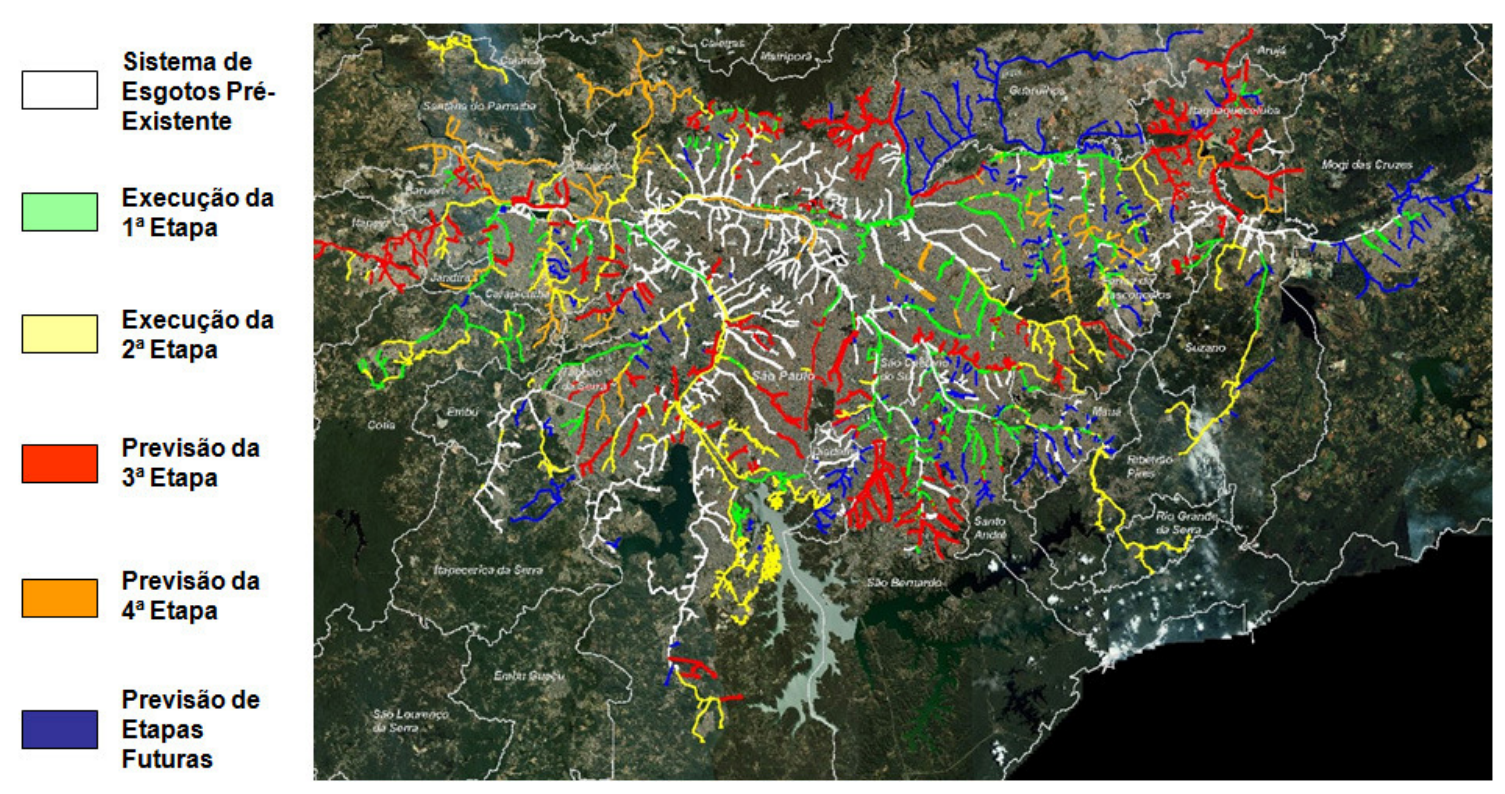

Figura 7 - Expansão de sistema integrado Fonte: Sabesp

Tabela 2 - Relação de coleta e tratamento de esgoto no Projeto Tietê

\begin{tabular}{c|c|c|c|l}
\hline Período & Fase & $\begin{array}{c}\text { Coleta de } \\
\text { esgoto }\end{array}$ & $\begin{array}{c}\text { Tratamento } \\
\text { de esgoto }\end{array}$ & Investimento \\
\hline & 1 & $78 \%$ & $63 \%$ & US\$ 1,1 bilhão \\
\hline $1992-$ & 2 & $84 \%$ & $70 \%$ & US\$ 500 \\
\hline $2002-$ & 3 & $87 \%$ & $84 \%$ & US\$ 1,05 \\
\hline $2009-$ & \multicolumn{3}{|c}{}
\end{tabular}

Fonte: Sabesp 
Anexo B - Áreas de Intervenção do Programa Vida Nova

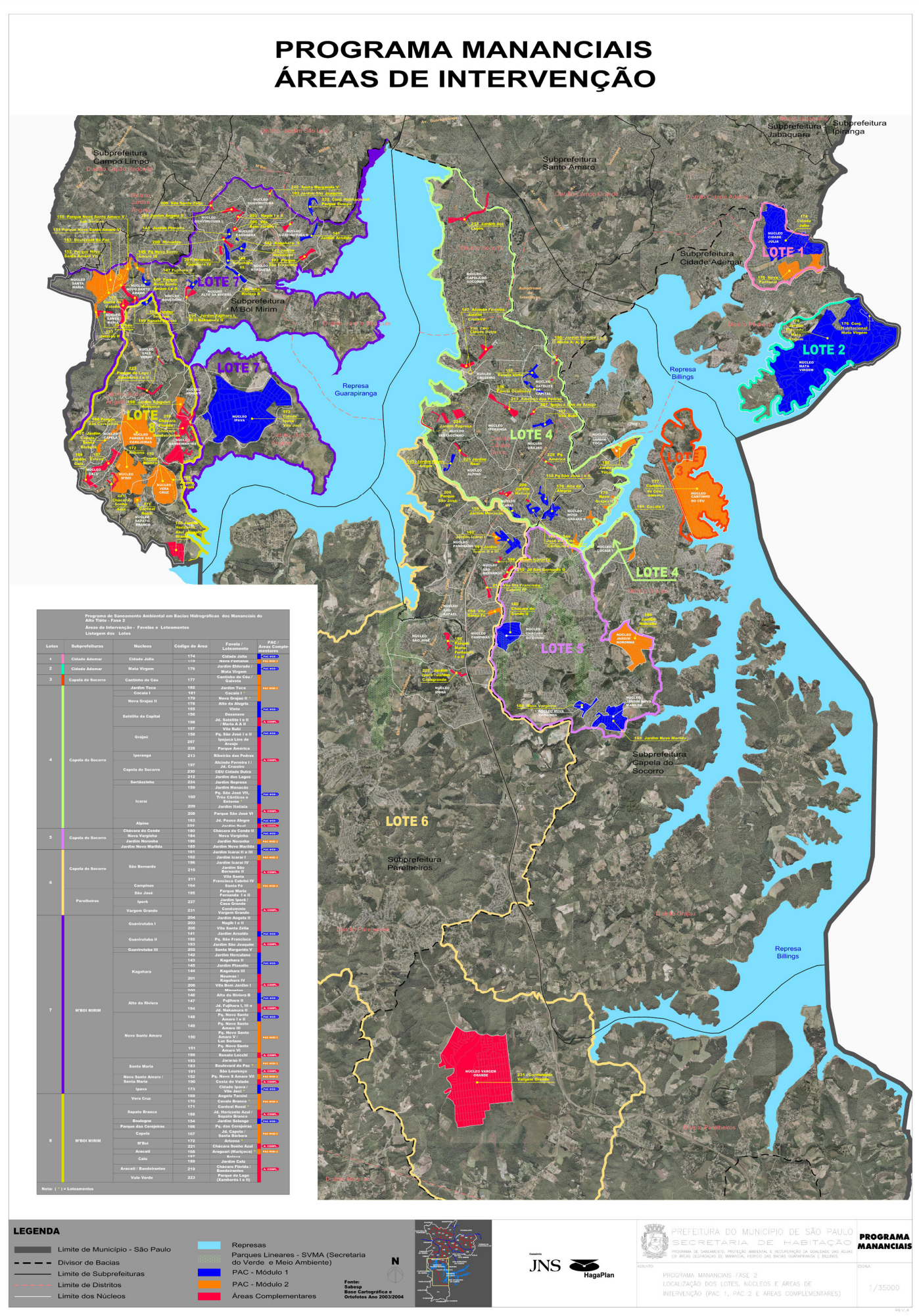

Figura 8 - Áreas de Intervenção do Programa Vida Nova Fonte: SEHAB - PMSP 


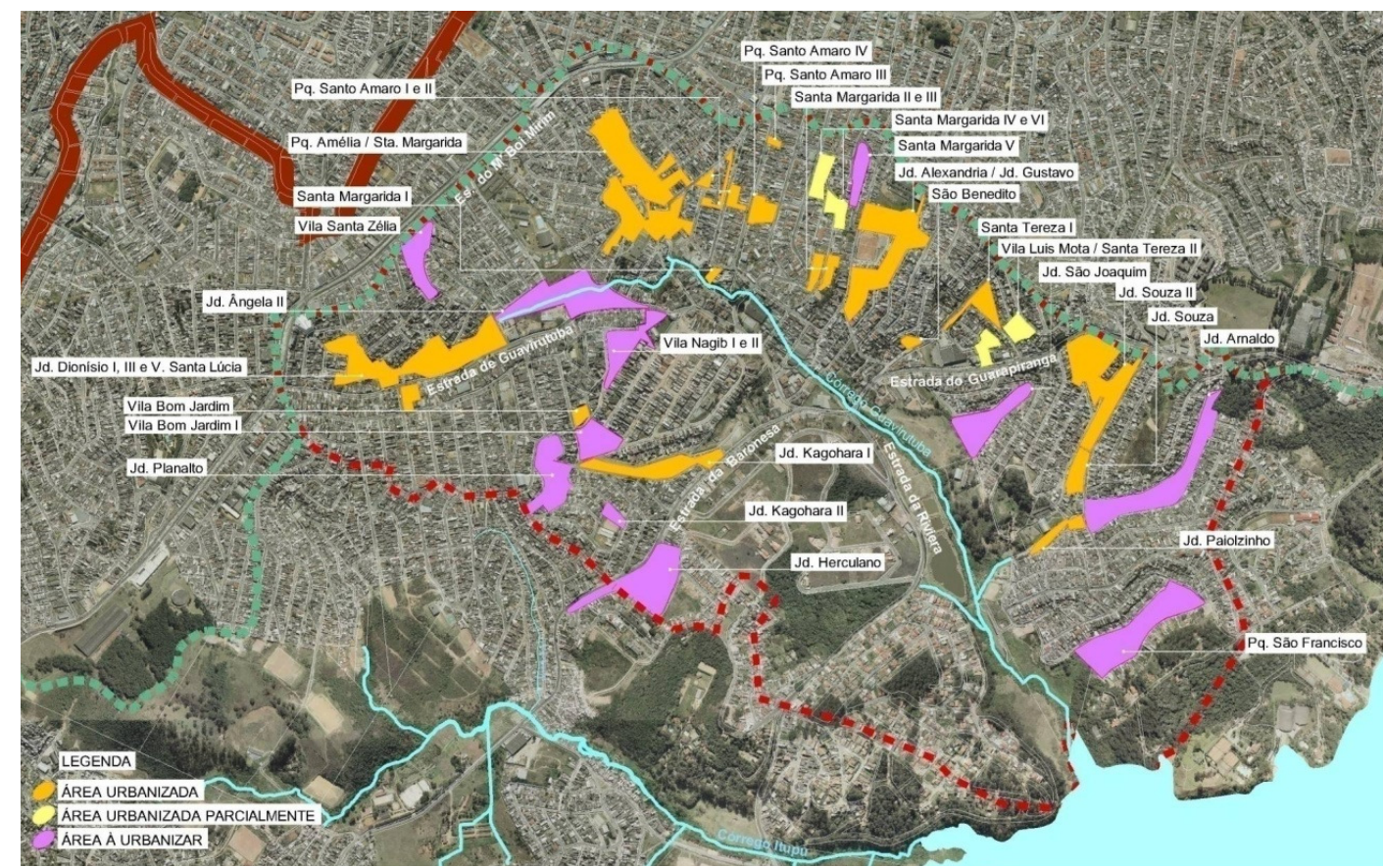

Figura 9 - Intervenção Bacia Guavirutuba - Fonte: SEHAB - PMSP

\begin{tabular}{|l|c|}
\hline \multicolumn{2}{|c|}{$\begin{array}{c}\text { Previsão de Término das Obras } \\
\text { Bacia Guavirutuba }\end{array}$} \\
\hline Jardim Arnaldo & Fevereiro/2012 \\
\hline Jardim Herculano & Março/2010 * \\
\hline Kagohara II & Abril/2012 \\
\hline Parque São Francisco & Abril/2012 \\
\hline Santa Margarida V & Abril/2012 \\
\hline Jardim Angela II & Abril/2012 \\
\hline Vila Bom Jardim I & Abril/2012 \\
\hline Vila Nagib I e II & Abril/2012 \\
\hline Vila Santa Zélia & Abril/2012 \\
\hline Jardim Planalto & Abril/2012 \\
\hline
\end{tabular}

Quadro 3 - Fonte: SEHAB / PMSP 


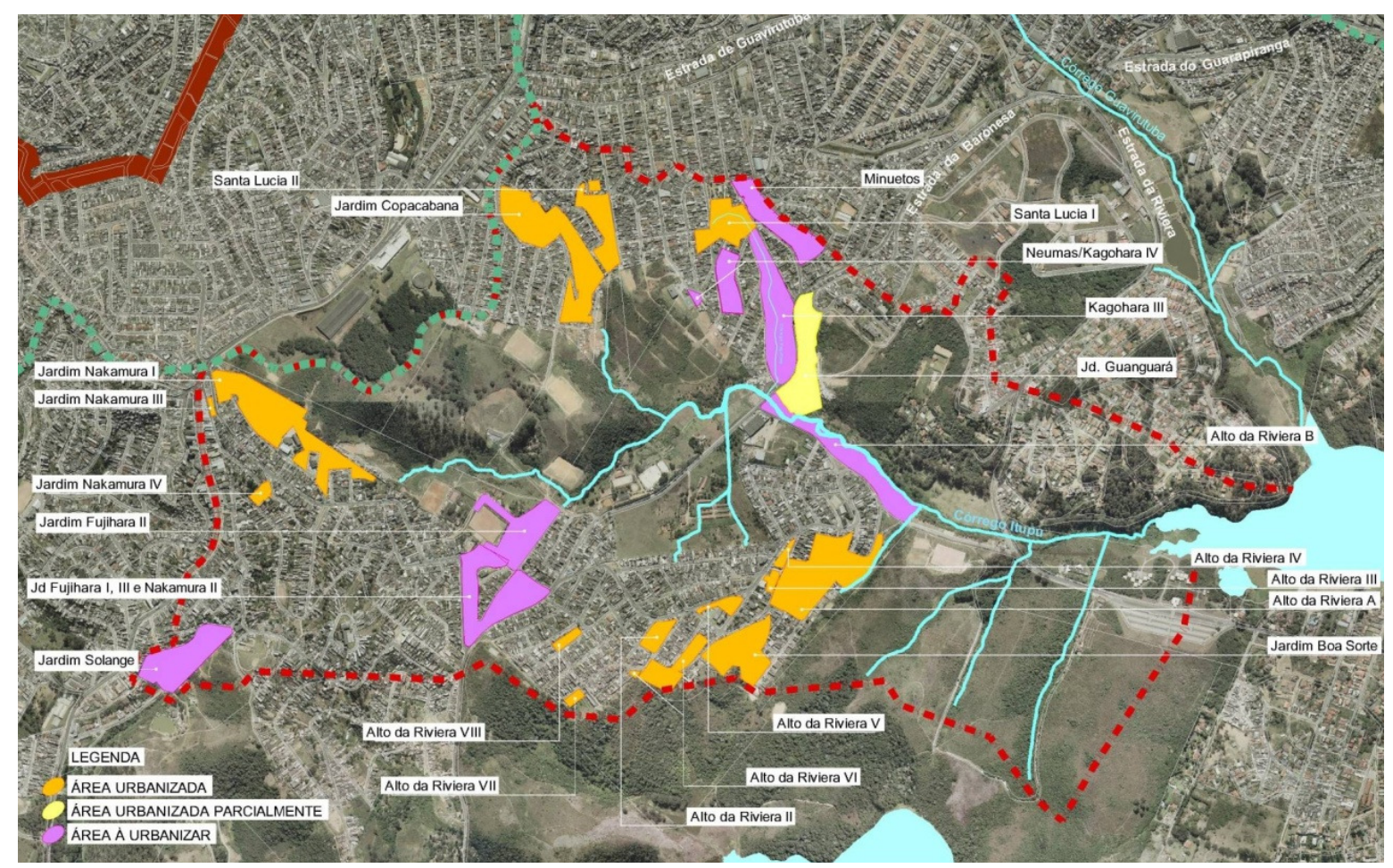

Figura 10 - Intervenção Bacia itupu - Fonte: SEHAB - PMSP

\begin{tabular}{|l|c|}
\hline \multicolumn{2}{|c|}{$\begin{array}{c}\text { Previsão de Término das obra } \\
\text { Bacia Itupu }\end{array}$} \\
\hline Neumas / Kagohara IV & Abril/2012 \\
\hline Minuetos & Abril/2012 \\
\hline Alto da Riviera B & Janeiro/2012 \\
\hline Fujihara II & Dezembro/2011 \\
\hline Jd. Fujihara I e III e Jd. Nakamura II & Abril/2012 \\
\hline Jardim Solange & Fevereiro/2012 \\
\hline
\end{tabular}

Quadro 4 - Fonte: SEHAB / PMSP 


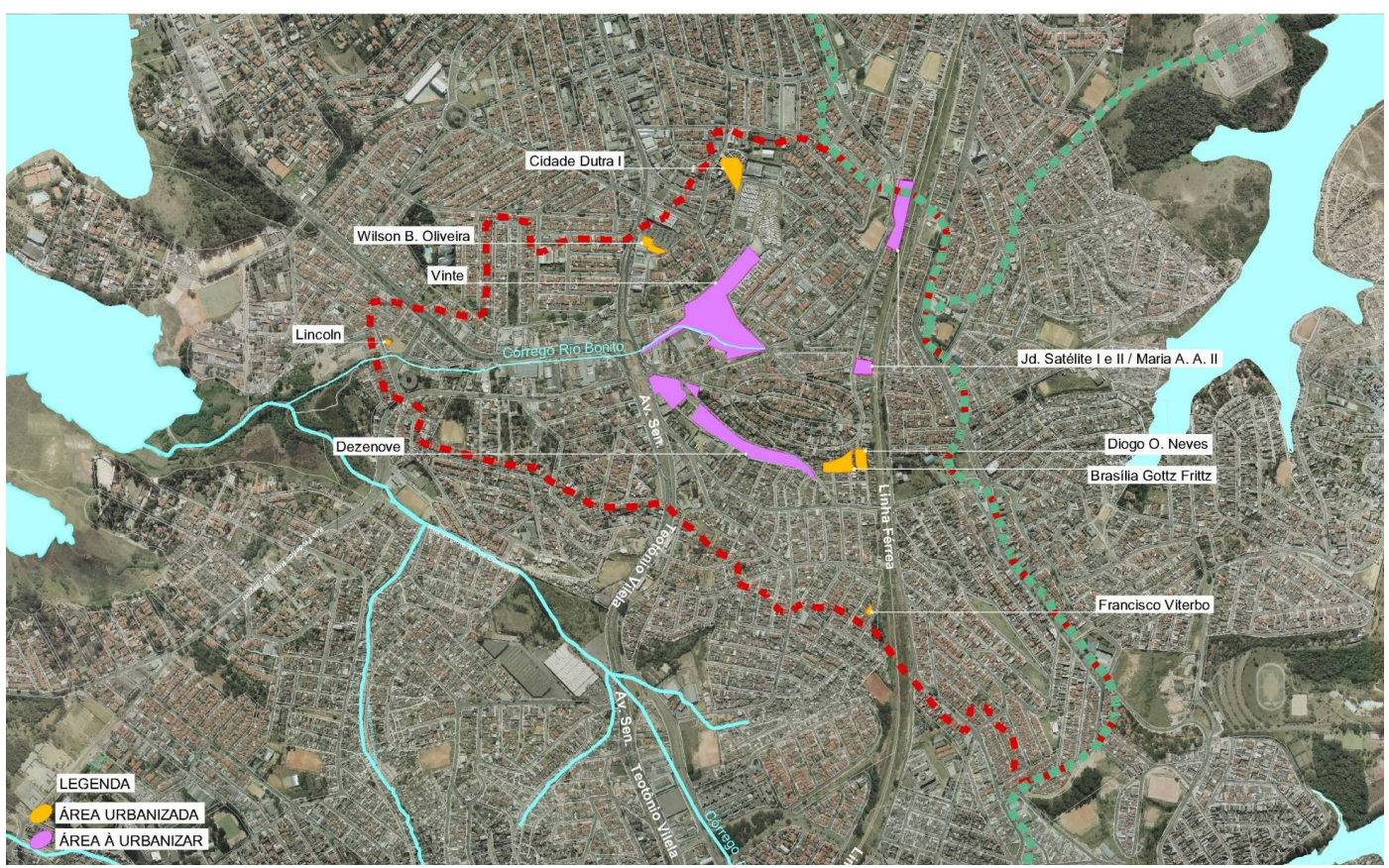

Figura 11 - Intervenção Bacia Rio Bonito - Fonte: SEHAB - PMSP

\begin{tabular}{|l|c|}
\hline \multicolumn{2}{|c|}{ PREVISÃO DE TÉRMINO DAS OBRAS } \\
Bacia Rio Bonito \\
\hline Dezenove & Junho/2010* \\
\hline Vinte & Junho/2010* \\
\hline Satélite I e II / Maria A. A. II & Abril/2012 \\
\hline
\end{tabular}

Quadro 5 - Fonte: SEHAB / PMSP 


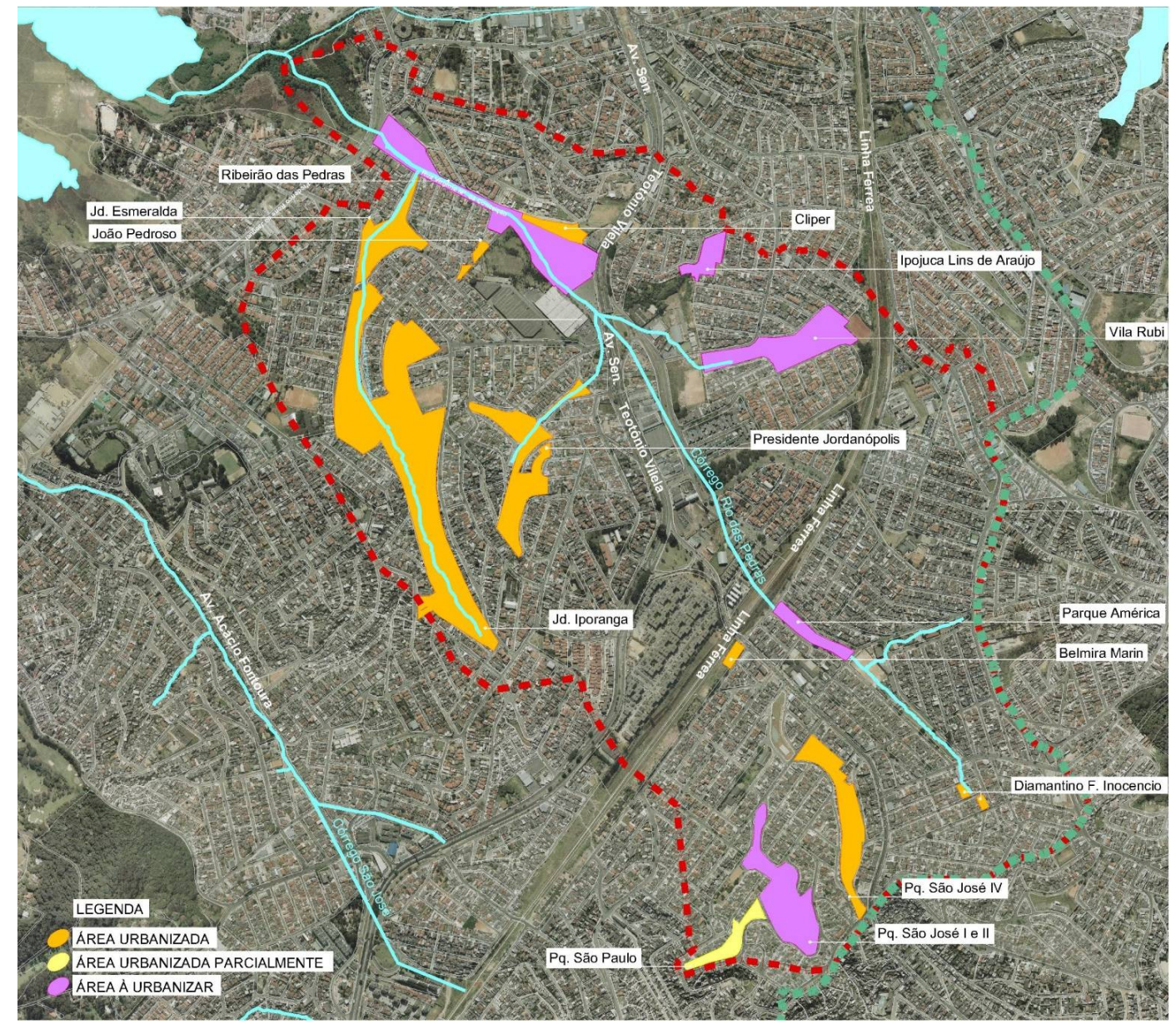

Figura 12 - Intervenção Bacia Rio das Pedras - Fonte: SEHAB - PMSP

\begin{tabular}{|l|c|}
\hline \multicolumn{2}{|c|}{$\begin{array}{c}\text { Previsão de Término das Obras } \\
\text { Bacia Rio das Pedras }\end{array}$} \\
\hline Ribeirão das Pedras & Obras concluídas \\
\hline Ipojuca Lins de Araújo & Agosto/2010* \\
\hline Vila Rubi & Agosto/2010* \\
\hline Parque América & Obras concluídas \\
\hline São José I e II & Abril/2012 \\
\hline
\end{tabular}

Quadro 6 - Fonte: SEHAB / PMSP 


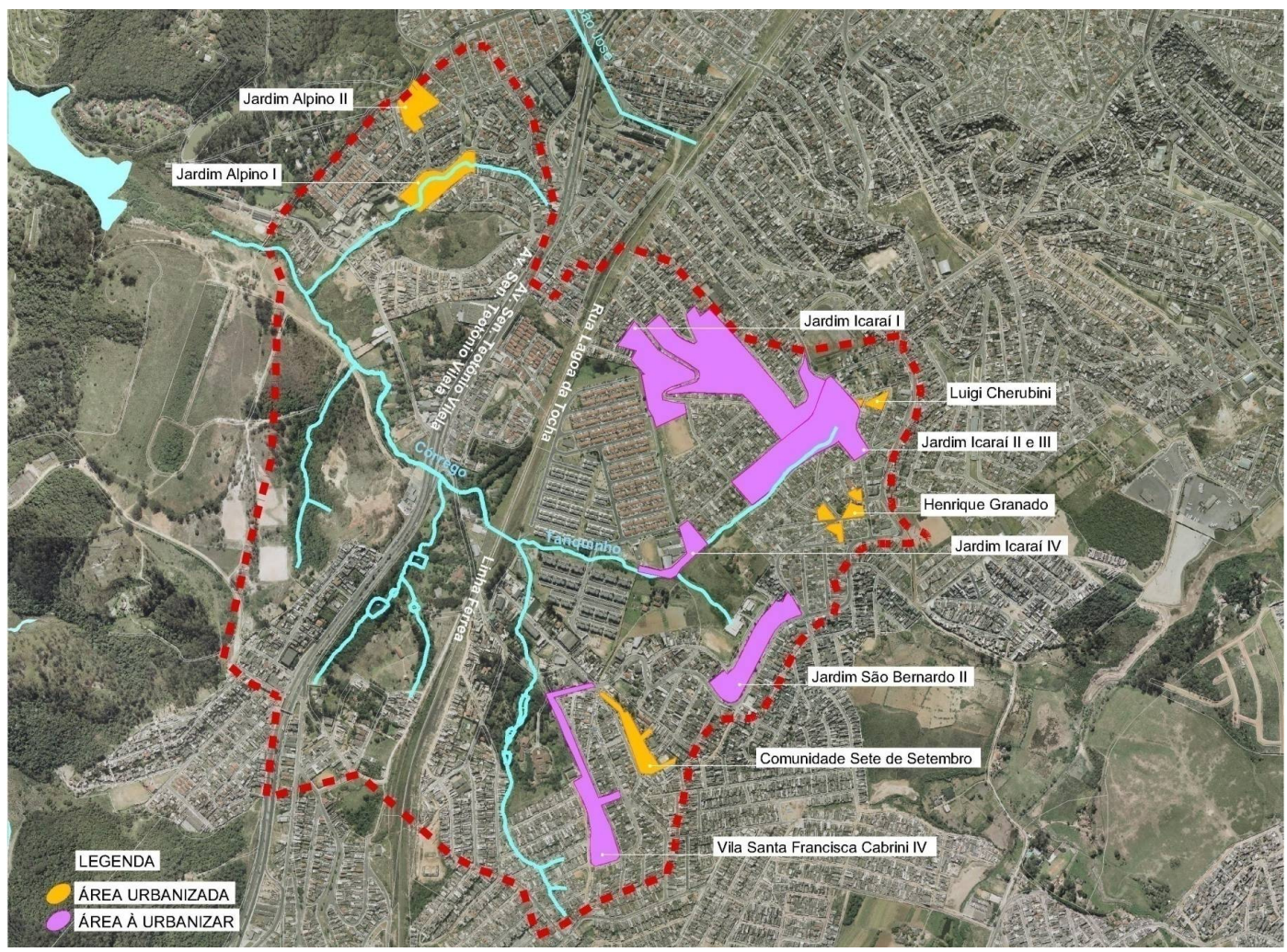

Figura 13 - Intervenção Bacia Tanquinho - Fonte: SEHAB - PMSP

\begin{tabular}{|l|c|}
\hline \multicolumn{2}{|c|}{$\begin{array}{c}\text { Previsão de Término de Obras } \\
\text { Bacia Tanquinho }\end{array}$} \\
\hline Icaraí I' & Março/2010* \\
\hline Icaraí II e III & Março/2010* \\
\hline Icaraí IV & Março/2010* \\
\hline São Bernardo II & Março/2010* \\
\hline Santa Francisca Cabrini IV & \\
\hline
\end{tabular}

Quadro 7 - Fonte: SEHAB / PMSP 


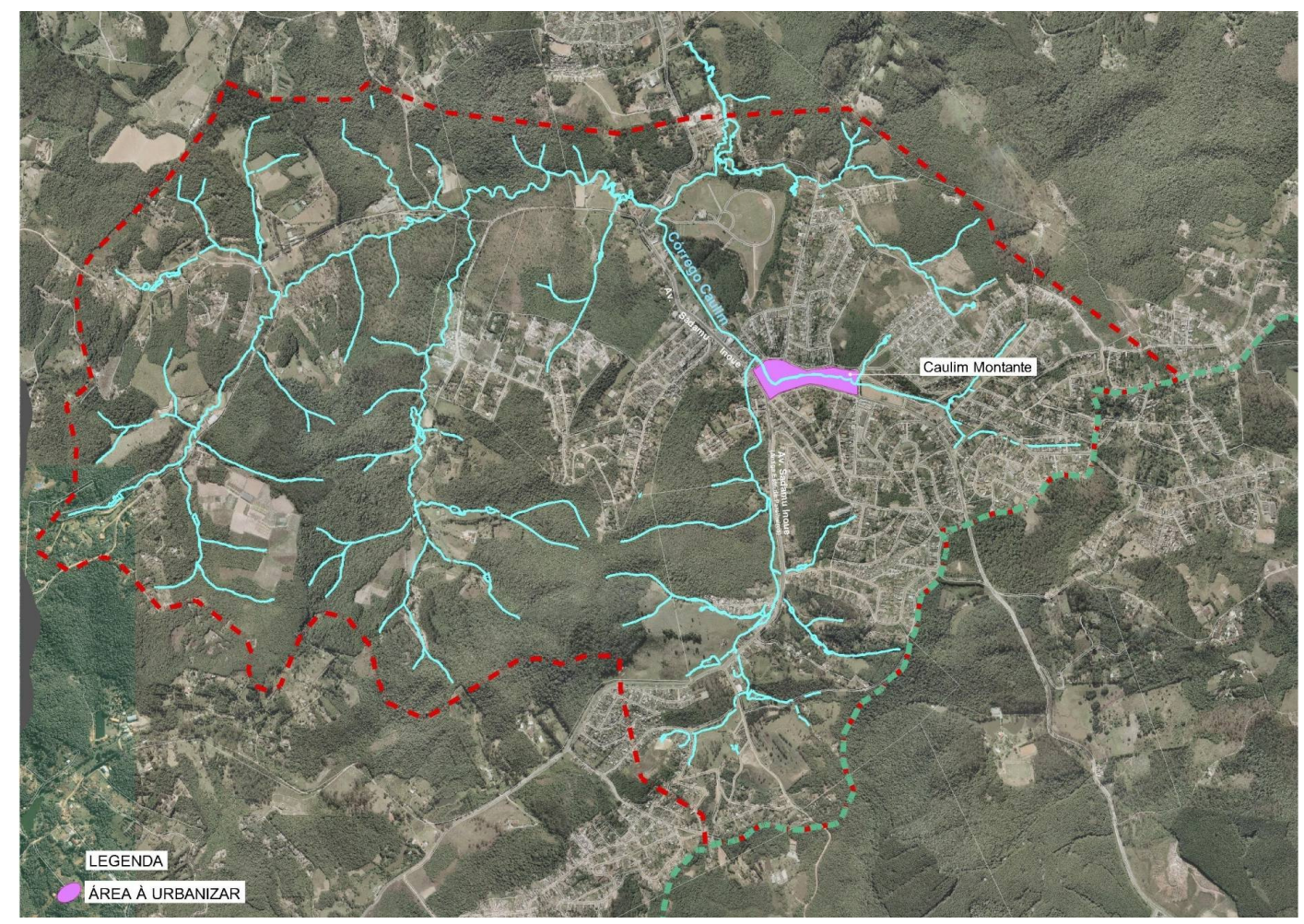

Figura 14 - Intervenção Bacia Culin Montante - Fonte: SEHAB - PMSP

\section{Previsão de Término de Obras \\ Bacia Culin Montante}

\begin{tabular}{l|l} 
Caulim montante & Dezembro/2010*
\end{tabular}

Quadro 8 - Fonte: SEHAB / PMSP 


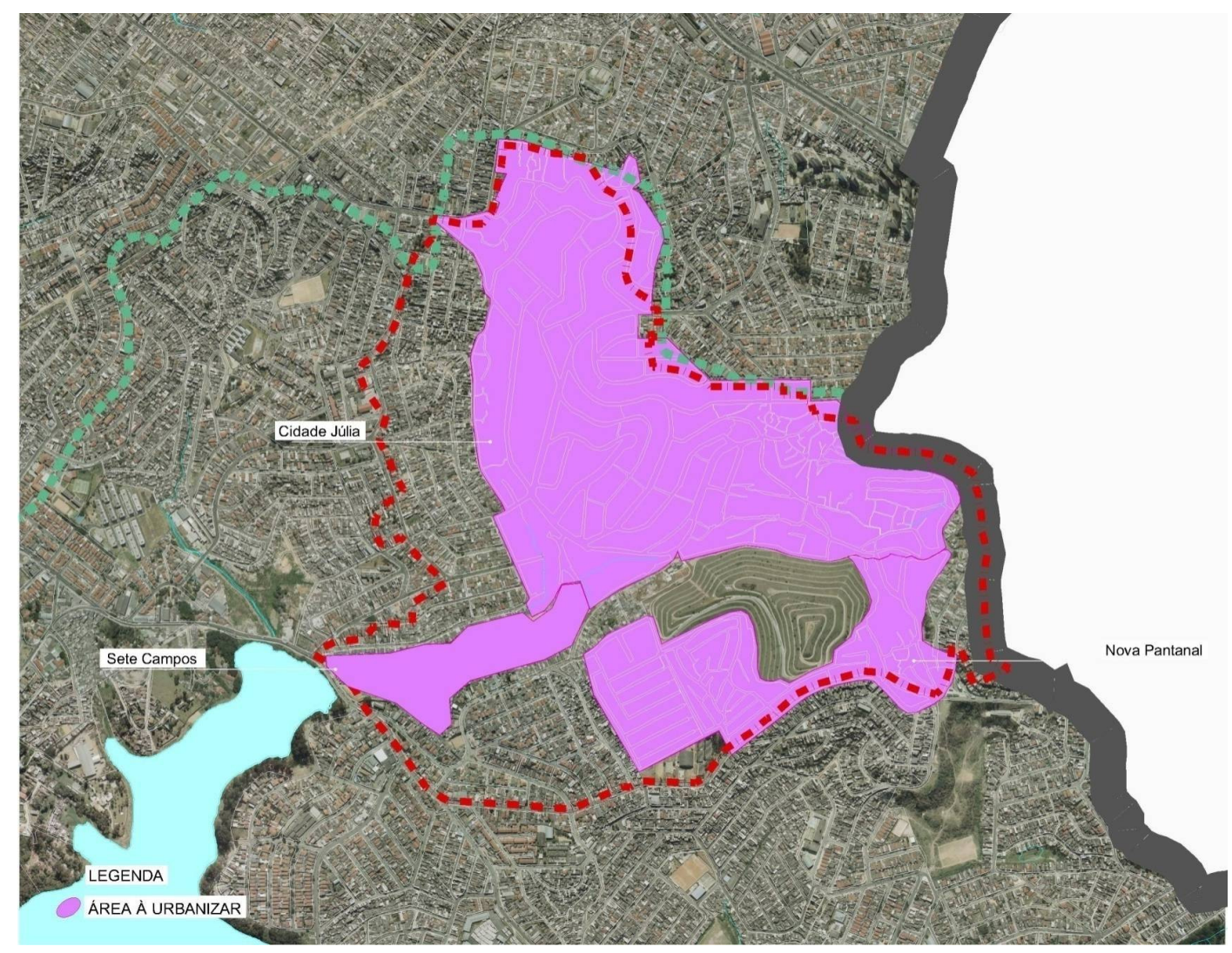

Figura 15 - Intervenção Bacia 7 Campos - Fonte: SEHAB - PMSP

\begin{tabular}{|l|c|}
\hline \multicolumn{2}{|c|}{$\begin{array}{c}\text { Previsão de Término das Obras } \\
\text { Bacia 7 Campos }\end{array}$} \\
\hline Cidade Júlia & Outubro/2011 \\
\hline Nova Pantanal & Abril/2012 \\
\hline Sete Campos & Julho/2010* \\
\hline
\end{tabular}

Quadro 9 Fonte: SEHAB / PMSP 
Anexo C - Áreas de intervenção do Córrego Limpo

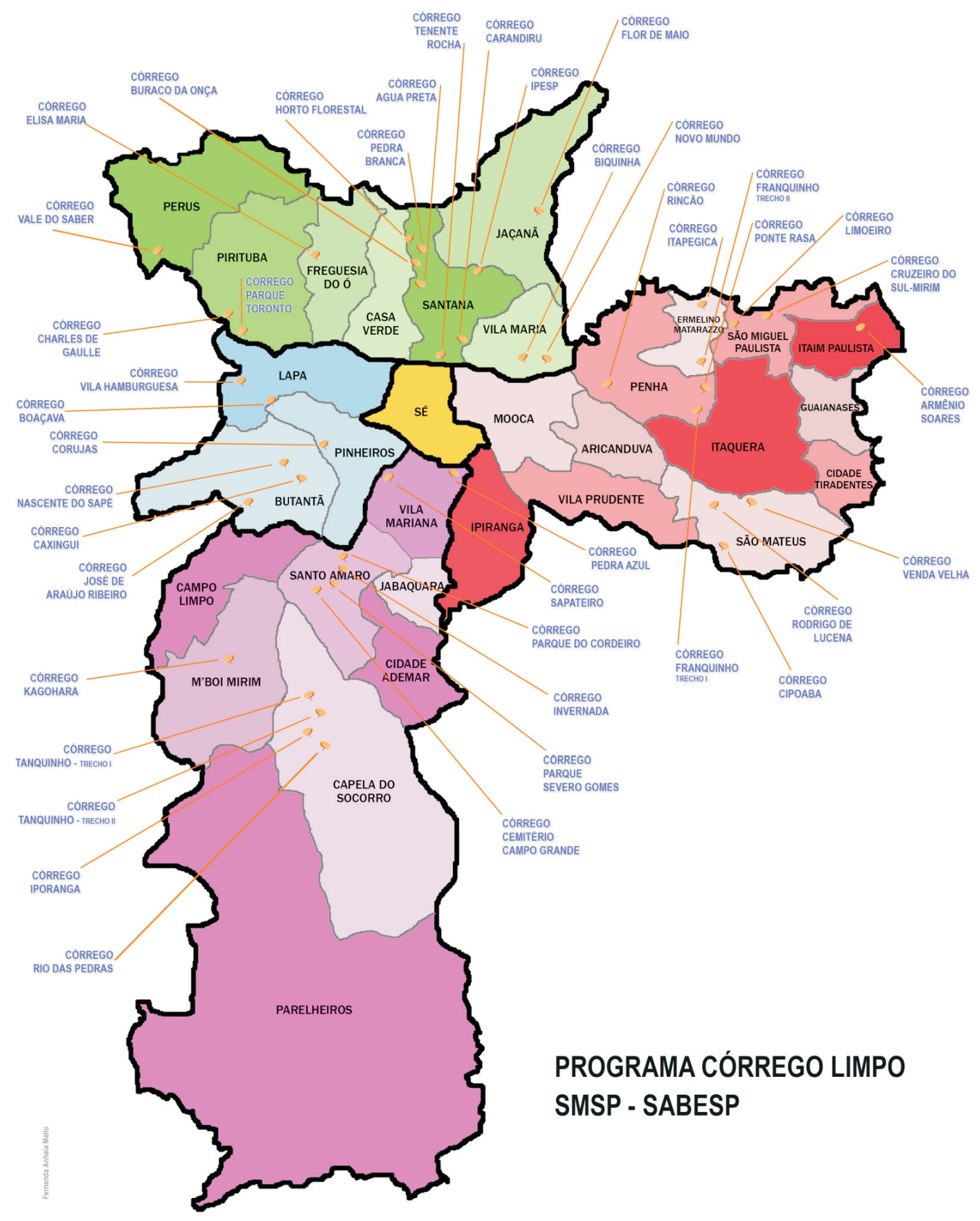

Figura 16 - Áreas de intervenção do Córrego Limpo

Fonte: PMSP 